Pervinca Rista

\title{
At the origins of Classical opera
}

Carlo Goldoni and the
dramma giocoso per musica

Carlo Goldoni and the
dramma giocoso per musica
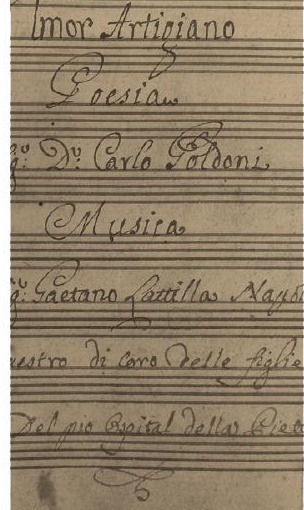
Venetian playwright and pioneer of modern theatre Carlo Goldoni (1707-1793) led a 'double life' as a librettist, authoring nearly as many libretti as comedies- libretti which, born from the same mind and the same hand that brought forth his famous, and famously controversial, overhaul of the practices of comic theatre, could not but push the limits of the standing tradition to open a new chapter in opera history. Goldoni became one of the first to give shape to the dramma giocoso per musica, an innovative, realistic, and enduring new genre with intimate connections to prose comedy that met with overwhelming international success, becoming the foundation for the works of future generations, including W. A. Mozart and his Italian librettist Lorenzo da Ponte. Perhaps because of his stature and influence as a comic playwright, Goldoni has rarely been considered as an innovator in the musical sphere. This study aims to shed new light on his primary role in the evolution of Classical opera, and on the legacy of his innovations in the European musical tradition.

aria Musicologica

Pervinca Rista (b. Italy) holds a PhD in Comparative Literature (Johns Hopkins University, Baltimore, MD, USA), along with numerous advanced degrees in Violin Performance earned in both the US and Italy. She has won numerous academic and musical awards, and performs concerts regularly worldwide. She has authored texts for music, has translated numerous works from Italian to English, and has published research in class-A international journals. Her research and teaching interests include the history of Italian literature and culture, the relationship between literature and music, the history of opera, and Italian comic theatre of the Enlightenment. She is a Marie Curie Research Fellow based at Ca' Foscari University in Venice, having won an Individual Fellowship grant from the European Commission for her original project "GoldOpera: Carlo Goldoni and Europe's New Opera Theatre." 
At the origins of Classical opera

Pervinca Rista - 978-3-0343-3564-5

Downloaded from PubFactory at 01/11/2019 02:35:03AM

via free access 


\section{Varia Musicologica}

Herausgegeben von

Peter Maria Krakauer

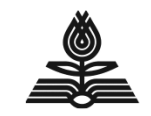

PETER LANG

Bern $\cdot$ Berlin $\cdot$ Bruxelles $\cdot$ New York $\cdot$ Oxford $\cdot$ Warszawa $\cdot$ Wien 
Pervinca Rista

\section{At the origins of Classical opera}

Carlo Goldoni and the "dramma giocoso per musica" 
Bibliographic information published by die Deutsche Nationalbibliothek

Die Deutsche Nationalbibliothek lists this publication in the Deutsche

Nationalbibliografie; detailed bibliographic data is available on the Internet

at 〈http://dnb.d-nb.de`.

British Library Cataloguing-in-Publication Data: A catalogue record for this book is available from The British Library, Great Britain.

Library of Congress Control Number: 2018946493

Cover illustration: Gateano Latilla, L'Amor Artigiano (dramma giocoso in tre atti su libretto di Carlo Goldoni), 1761. MS I 12, from the holdings of the Biblioteca del Conservatorio Giuseppe Verdi, Torino (Italy). Use by permission.

This project has received funding from the European Union's Horizon 2020 research and innovation programme under the Marie Sklodowska-Curie Individual Fellowship grant agreement n.701269.

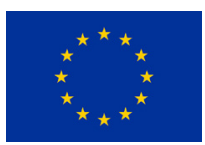

ISSN $1660-8666 \mathrm{pb}$.

ISSN 2235-5685 eBook

ISBN 978-3-0343-3551-5 pb.

ISBN 978-3-0343-3563-8 eBook

ISBN 978-3-0343-3564-5 EPub

ISBN 978-3-0343-3565-2 Mobi

DOI $10.3726 / \mathrm{b} 14367$

\section{PETER LANG}
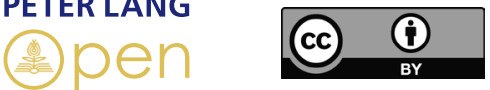

Open Access: This work is licensed under a Creative Commons Attribution 4.0 unported license. To view a copy of this license, visit https://creativecommons.org/licenses/by/4.0/

This publication has been peer reviewed.

(C) Pervinca Rista, 2018

Peter Lang AG, International Academic Publishers, Bern 2018

Wabernstrasse 40, CH-3007 Bern, Switzerland

bern@peterlang.com, www.peterlang.com 


\section{Table of Contents}

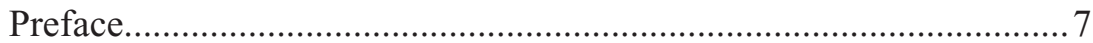

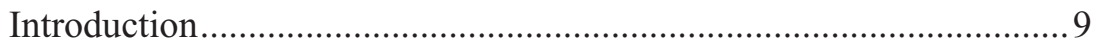

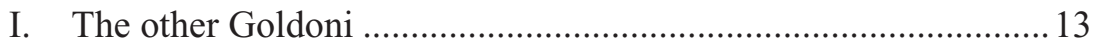

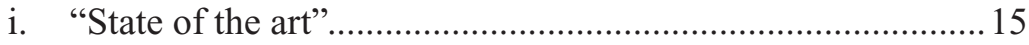

II. The foundations of musical comedy ........................................... 19

i. The limits of opera seria ......................................................20

ii. Naples and the commedia per musica ...................................24

iii. Venice and the intermezzo..................................................... 34

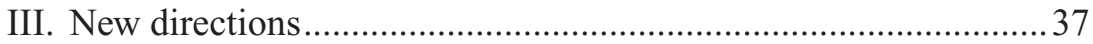

i. Goldoni's apprenticeship with musical texts......................... 37

ii. New directions for comedy ..................................................51

iii. A new art for a new society: the dramma giocoso takes shape in Venice .............................................................55

IV. A new source for Classical opera: Goldoni's drammi giocosi......63

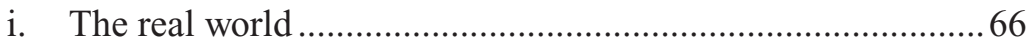

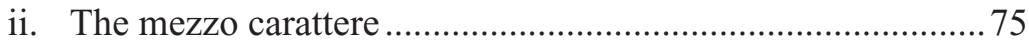

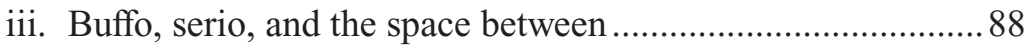

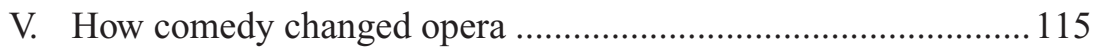

i. The musical elements of comedy....................................... 117

ii. Comedies that became drammi giocosi ............................. 130

iii. Goldoni as musical reformer ............................................ 147

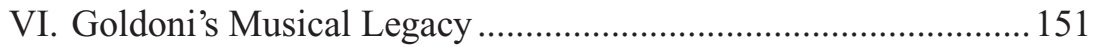

i. Globalization? Old news! International drammi giocosi and diffusion of a new genre................................. 152

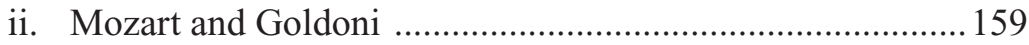

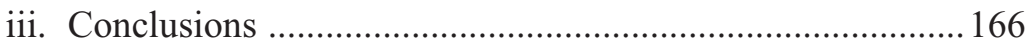


Pervinca Rista - 978-3-0343-3564-5

Downloaded from PubFactory at 01/11/2019 02:35:03AM

via free access 


\section{Preface}

This book explores the origins and evolution of Classical opera, a musical tradition so unique with respect to those that preceded and followed. In particular, we travel to $18^{\text {th }}$ century Venice and into the world of Carlo Goldoni, a Venetian lawyer who, in adolescence, ran away from school to join a troupe of traveling actors. His father held high hopes for his diplomatic career, but his own life and all his hopes lay in theatre. His true calling was comedy.

Goldoni wrote comedies for the musical stage, too. In fact, close to 100 libretti. He became so famous as a playwright that, to this day, the public knows little of his 'musical' career, yet it had a tremendous impact on how Classical opera developed. In the past, researchers separated his theatrical texts from his musical texts, but when considered together, new discoveries come to the surface.

We will trace the history of Classical opera and its signature genre, the dramma giocoso per musica, from its early antecedents to its fully evolved form. Traveling from the Neapolitan commedia per musica and the Venetian intermezzo, through Goldoni's adventures in experimentation, all the way to the Mozart/da Ponte operas, we will uncover how Carlo Goldoni, a pioneer of realist theatre, unified past traditions to sculpt and canonize a new musical art for modern times.

The progressive impulse he gave to opera, transforming musical 'comedies' into works of social significance and psychological depth, is intimately connected to his transformation of theatrical comedy. A man of the Enlightenment, Goldoni dedicated his life's work to restoring theatre, whether musical or prose, to its highest potential, that is as the realistic portrayal of the contemporary world. Classical opera still speaks to us, and still fills theatres in the $21^{\text {st }}$ century, for its ability to shine a critical light on the contradictions of our society, and on the universal human condition. Goldoni was the first to invest opera with this extraordinary potential, and he could not have changed this musical art so completely without his experience and vision for literary innovation 
in prose theatre. His life and his legacy are a vibrant testimony to the intimate complementarity of the arts.

Taking example from Goldoni, more broadly this book was born from a desire to connect the world of the humanities to the world of music. Worlds that thrive on one and the same thing: human creativity, which, history has shown us, is limitless. 


\section{Introduction}

No composer nor librettist in Western music has left to posterity the impression that his works were created in leisure, and without immense effort. Opera had scarcely been born that Monteverdi wrote of his second work, "Io mi riducessi quasi alla morte nel scrivere 1'Arianna." Even so, the age of Enlightenment consumed theatre like no other moment in history, as what was once the privilege of few and noble patrons was becoming public domain for the first time. Venice like no other European city desired and cultivated theater of all types, both on the stage and in the presses, which consolidated and exported novelties in entertainment at all levels. It is no coincidence that Europe's first public theatre was Venetian, and quite ahead of the times. Not to mention, the Teatro San Cassiano to which we refer, which opened its doors to ticket-bearing spectators from all walks of society in 1636, was born as an opera house. To put things in perspective, Paris in the $18^{\text {th }}$ century, while reputed of the most cultured cities in Europe, housed three principal theatres: the Opéra Comique, the famous Comédie Française (La maison de Molière, as it was known), and the Comédie Italienne, of which Goldoni would later take charge. Venice, during the same years, housed no less than thirteen, all in competition for the newest exclusive texts and largest crowds. It is an understatement to say new works were desired and sought by impresari and by popular and refined audiences alike. They were a necessity.

If today, after Verdi, Puccini, and Wagner, we are well accustomed to supposing a text created only for- and according to- the specific requirements of a single musical rendition, returning to the early 1700 s and to Goldoni, we encounter a radically different practice. Goldoni's texts belong to a period in history, and a concept of opera theatre, that neither required nor sought shared work on a text

1 Cited in Enrico Fubini, Musica e Pubblico dal Rinascimento al Barocco (Torino: Einaudi, 1984); 97. I reduced myself to near death in writing Arianna. 
and a score. The real requirements were versatility and quickness of preparation to meet overwhelming demand. This is not to say that Goldoni never made adjustments, and most importantly, in keeping with his realist inclinations, he fashioned his characters according to the strengths of his performers, when he knew them. It is important to understand, however, that the mode of work and the intention behind his texts for music was altogether different from what later tradition has dictated.

To this we must add Goldoni, who was not a man to refuse any challenge. Still today scholars wonder at the famous, or better infamous, "anno delle sedici commedie" (year of the sixteen comedies), that is the 1750-51 season in which he surpassed all conceivable expectations. The Teatro Sant'Angelo habitually put on eight new works from late summer to Carnevale, but in the face of raging competition, Goldoni struck a wager with its impresario Girolamo Medebach (who was renting it from a society of aristocratic proprietors, and could more willingly make room for Goldoni's experimental new comedies), to supply exactly twice as many- a bet that paid off with his employer and his audiences. The comedies Goldoni wrote during that ambitious season turned out to be some of his most enduring works, and he still managed to create more than one dramma giocoso on the side.

Musical scores that use Goldoni's texts are so many as to still be uncounted, dispersed in libraries all over the world. This corpus is simply too vast, too varied, and too subjective to receive just treatment within a single book. Far more important, a text-based approach is mandated by the inherent nature of Goldoni's work and times. For these reasons, this volume is not intended to supply full analysis of musical scores (which have, however, been reviewed and on occasion transcribed). In this historical period it is text alone that supplies form, subdivision, meter, content, and all of those elements that music relies on to shape its rhythms, harmonic discourse, and color. Moreover, text alone assures continuity amidst the changeability of musical permutations. It is the foundation for all that follows, and the most direct conduit for innovation. The composers who set Goldoni's texts to music, will, however, be key to understanding the dissemination of the dramma giocoso and its canonization across Europe. Among them we find Franz Joseph Haydn 
and even the young W. A. Mozart, whose very first opera was drawn from Goldoni's La finta semplice (1764). ${ }^{2}$

We can now venture to revisit Goldoni's Venice and cast a light on his texts for music, in relation to the musical tradition that preceded and followed, as well as to his controversial techniques a playwright. Instead of separating libretti and comedies as has most often been done, it is most fruitful, and philologically reasonable, to consider them in close comparison. Plays and libretti, after all, came from the same mind, were written contemporaneously, and not rarely for the same audience. Some even share plots, characters, and verses. Their close connection can uncover the influence- vast and enduring- of one man's pen.

2 In a version revised by Marco Coltellini (1724-1777), successor to Pietro Metastasio as Imperial poet at the Viennese court. 
Pervinca Rista - 978-3-0343-3564-5

Downloaded from PubFactory at 01/11/2019 02:35:03AM

via free access 


\section{The other Goldoni}

Carlo Goldoni's comedies are three hundred years old, but have remained very much part of our culture. Adaptations, spin-offs, and modern translations are found in abundance. Valued for their unfailing humor and artful design, these texts are also natural conduits of Enlightenment ideologies so in harmony with our own views of society and the individual. The powerful injection of realism Goldoni's life work gave to theatre, clear symptom of a turning point in history, cost him a good deal of strife but secured him an enduring legacy as a theatrical innovator. ${ }^{3}$ Given his stature as a playwright, it comes as no surprise that Goldoni is less often remembered as something else: not the lawyer his contemporaries knew him as, but a librettist.

Goldoni wrote opera libretti during the entire course of his life. In fact, his first creative writings as a teenager reluctant to study law weren't comedies but texts for music, and when, in the last years of his life and embittered by disappointments, he stopped writing comedies, he continued to create libretti. In his close to 100 texts for music, Goldoni tried his hand at nearly everything: short comic intermezzi, melodrammi seri in the style of Zeno and Metastasio, drammi eroicom$i c i$, divertimenti per musica, and drammi comici, before settling on his genre of choice and writing nearly 50 drammi giocosi. During his lifetime and beyond, Goldoni's libretti were set to music by composers of international reputation: Antonio Vivaldi, Baldassarre Galuppi, Niccolò Piccinni, Gaetano Latilla, Giuseppe Scarlatti, Giovanni Paisiello, and outside of Italy Franz Joseph Haydn and Wolfgang Amadeus Mozart to name but a few. Their operas were performed well beyond Italy and

3 From the canovacci of the Commedia dell'Arte Goldoni was the first to steer actors and audiences towards developed, realistic, and socially relevant comedy. For a synthesis see Siro Ferrone, La vita e il teatro di Carlo Goldoni (Venezia, Marsilio, 2011). 
Europe, even reaching Moscow and the young United States before the turn of the $19^{\text {th }}$ century.

Just as he was an innovator in comic theatre, Goldoni applied many of the same principles to his texts for music, drawing his characters from contemporary society. The libretti of Goldoni's mature years in particular, the drammi giocosi per musica, occupy an innovative position among theatrical genres. Carlo Goldoni defined this nascent genre as "materia buffa... intrecciata colla seria,"4 that is, comic material interwoven with tragic, a new coexistence capable of yielding a broader spectrum of dramatic registers and a more complex representation of social types than ever before achieved in theatre. His drammi giocosi reflect a priority for realism in their psychological depth, conversational dialogue, and expanded ensembles, all elements quintessential to later Mozartean opera.

The true nature and entity of our debt to Goldoni the librettist, however, has not yet been disclosed by the numerous studies conducted on his texts. His early intermezzi remain the most frequent object of attention, no doubt a consequence of the author's own tendency, in his retrospective Memoires as elsewhere, to frame them as the early seeds from which his great comedies grew. ${ }^{5}$ Most notably, with the exception of Ted Emery's Goldoni as Librettist, ${ }^{6}$ no study has yet been produced on the dramma giocoso as a distinct operatic genre, though the majority of Goldoni's libretti, especially those written during the "reform" years, as a mature author with very clear ideas for the future of comedy, are of this kind. To better understand the purpose of the following chapters, it can be useful to know something of what previous research has offered on the topic.

4 Carlo Goldoni, La Scuola Moderna, "All'amico lettore."

5 "Les traits comiques que j'employais dans les intermèdes, étaient comme de la graine que je semais dans mon champ, pour y récueillir un jour des fruits mûrs et agréables," Memoires de Goldoni, pour servir à l'histoire de sa vie et a celle de son théatre, Paris, Ponthieu, 1822; 152.

6 Ted Emery, Goldoni as Librettist, Theatrical Reform and the Drammi Giocosi per Musica, Peter Lang Press, 1991. 


\section{i. "State of the art"}

Early studies of Goldoni's opera texts appeared to immediately sense a synergic relationship between comedies and libretti. Patrick Smith, for example, believed that "Goldoni's librettistic work is everywhere a reflection of his work for the theatre," degrees by Luigi Falchi, who considered the libretti "sostrato del pensiero dello scrittore," 8 by Manilo Dazzi, and by Edmondo Rho, who argued that between libretti and plays "le linee di sviluppo psicologico ed artistico sono le medesime." A A radically different approach began with Giuseppe Ortolani, a founding figure of Goldoni studies in Italy, who considered the opera texts starkly inferior to the author's works for spoken theatre, dismissing them as undeserving of any real scrutiny. For him, in the drammi giocosi, "Il commediografo veneziano non riuscì a creare nessun capolavoro, nulla di letterariamente vitale," concluding that "invero queste vecchie farse per musica non reggono all'analisi critica, non appartengono alla storia letteraria." ${ }^{10}$ This approach, applied by later scholars as well, likely contributed to the general absence of studies on Goldoni as an opera source until recent times. Nicola Mangini also sought to distinguish Goldoni's libretti from his plays. For Mangini, these works were separate from the plays in the mind of the author, and therefore should only be understood in relation to the preceding opera tradition, and not to his other works. He writes: "Si tratta...di adottare una metodologia di approccio che non insista (come si è sempre fatto) nel confronto e nella relazione col suo [di Goldoni] teatro comico, ma che invece prenda in esame questi drammi per sé

$7 \quad$ La Missione teatrale di Carlo Goldoni (Bari: Laterza, 1936).

8 Intendimenti sociali di Carlo Goldoni (Roma: Società ed. Dante Alighieri, 1907). Substratus of the author's thought.

9 See La Missione teatrale di Carlo Goldoni (Bari: Laterza, 1936), and Intendimenti sociali di Carlo Goldoni (Roma: Società ed. Dante Alighieri, 1907). The paths of psychological and artistic development are one and the same.

10 Opere di Carlo Goldoni, edited by Giuseppe Ortolani (Verona: Mondandori, 1973) Vol. 10; 1257. The Venetian comic playwright did not succeed in creating any masterpiece, anything vital to literature. These old farces for music cannot hold up to critical analysis, and are not part of literary history. 
stessi nell'ambito specifico del loro genere, avendo come eventuale termine di riferimento la librettistica precedente o coeva."11

A first attempt to reconcile these disparate approaches is Ted Emery's Goldoni as Librettist. In his survey of Goldoni's texts for music, Emery identifies both structural (due to the rules of theatrical convention) and ideological differences with respect to the spoken plays, adopting Franco Fido's notion of reform and 'counter-reform.' In synthesis, Fido and Emery see an initial affinity between spoken theatre and libretti, followed by the progressive abandonment of the ideological agenda of the plays in the works for music, more readily employed for less realistic, more superficial, and at times fantastical content. ${ }^{12}$ Emery's conclusion is that "On the whole, the operas are, as Fido suggests, the artistic and ideological opposite of the commedie: less realistic than the plays, they often have fantastic or fanciful plots and a playful, punning style; lacking the reform's didactic intentions, they seek to entertain more than to instruct; rejecting middle-class morality, they give freer rein to disorder and incorporate a more negative vision of the world." ${ }^{13}$ While Emery's work offers valuable information on the varied nature of Goldoni's production, despite his title the author does

11 Nicola Mangini, "Itinerari e approdi di Goldoni librettista" in Rassegna di cultura e di vita scolastica, 83 (1985); 4. We must adopt an approach that does not insist (as has always been done) on the comparison to his comic theatre, but which instead examines these works in their own right, and with respect to their own field, possibly with reference to the preceding or coeval production of libretti.

12 In Fido's own words, “quello che la parola infeudata alla musica perdeva sul versante del referente- cioè in termini di capacità di evocare con efficacia mimetica e critica il mondo reale: mercanti, donne di casa, servitori, ecc.- essa guadagnava dalla parte del significante- scherzi e giochi di parole, paradossi e calembours, onomatopee e iperboli, equivoci e cacofonie plurilingui."

Franco Fido, "Riforma e controriforma del teatro. I libretti per musica di Goldoni fra il 1748 e il 1753," in Studi Goldoniani, vol. 7 (1985); 63. In his libretti what the text enslaved to music lost on the side of the referent- that is in terms of the capacity to evoke the real world with imitative and critical efficacy: merchants, housewives, servants, etc.- it gained on the side of the signifier- jokes and word games, paradoxes and puns, onomatopea and hyperbole, misunderstandings and multi-lingual cacophonies.

13 Ted Emery, Goldoni As Librettist: Theatrical Reform and the Drammi Giocosi per Musica (New York: Peter Lang Press, 1991); 77. 
not assess the dramma giocoso as an operatic type distinct from Goldoni's intermezzi. There is no investigation of the differences between buffo and serio characters, and no mention of the all-important mezzi caratteri, a novelty unique to the dramma giocoso and an integral part of fully formed Classical opera.

Furthermore, Emery's interpretation is conditioned by his definition of Goldoni's reform as almost exclusively the exaltation of the industrious merchant class. Consequently, he suggests that the author abandons his own ideals in those works that appear - but it is only appearance- more fantastical in nature (Il Mondo della Luna), or that ridicule exponents of the borghesia and not the aristocracy (including in the spoken theatre, with masterpieces such as Sior Todero Brontolon). Emery concludes, "when the commedie and comic operas are considered together as inseparable parts of an organic whole, the tension between reform and 'counter-reform' underscores a surprising sense of ideological fragility in an author who has traditionally been regarded as a bard of the bourgeoisie." ${ }^{14}$ If, in Goldoni's more mature works, the "middle-class morality" of his characters is no longer idealized but critiqued in its own right, far from "ideological fragility" this denotes ideological fiber of a certain tenacity. The limit of Emery's interpretation is that his narrow concept of reform excludes from consideration a number of works that instead have much to reveal with regards to Goldoni's strategies for modern theatre.

Goldoni's theatrical "reform," a term chosen by the author himself- retrospectively- to describe his overhaul of the theatrical common practice, has been reevaluated as a much broader undertaking, and unmistakably shaped his texts for music as well as his comedies. The idealization of the hard-working middle class often ascribed to Goldoni, given it is a signature of many works, is a clear symptom of Goldoni's historical circumstances. Predominant as it may be, it is not an exclusive goal, but rather a product of his criticism of the aristocracy, the target of the largest number of his works, and more than anything, a product of his desire for original characters. Merit, industry, and ingenuity are the virtues of Goldoni's present, in contrast to bloodline and

14 ibid.; 75. 
inheritance. These inevitably come to the forefront as the influence of the aristocracy, in economic crisis, begins to fade. Most importantly, Goldoni's critical eye never targets one social status or another, but seeks realism above all, the principal source of his theatrical innovation as of his social criticism. In fact, Goldoni's revision of comic theatre did not initiate from revolutionary choices in subject matter, but rather from technical changes that, in an effort to more realistically reflect contemporary life, gradually transitioned from the repertoire of the Commedia dell'Arte to a more pristine representation of modern society and its human archetypes. The moral hue of Goldoni's works hinges uniquely upon the realism of the parts that convey it. By transposing his contemporary world onto the stage, Goldoni was able to return theatre to its Horatian potential in a very modern way. In his words, his works were meant to “'(...) far vedere sul Teatro i difetti de' particolari, per guarire i difetti del pubblico, e di correggere le persone col timore di essere posto in ridicolo." 15 These concepts are most often applied to Goldoni's spoken comedies, but are a necessary foundation for understanding his musical texts as well.

The contributions of Mangini, Fido, and Emery have been followed by numerous more recent publications, including articles by Barbara Gizzi and Ilaria Crotti, ${ }^{16}$ recent conference proceedings, ${ }^{17}$ and a summary of current research by Siro Ferrone. ${ }^{18}$ These recent studies shed new light on the economic and managerial mechanisms of theatre, on specific biographical circumstances, and on the more successful artists who premiered his works, among other areas of interest, all in support of a more comprehensive approach to understanding the author's work. Again, however, little is said of the dramma giocoso, which we can now endeavor to discover.

15 Carlo Goldoni, La dama prudente, Forward. (...)to show the flaws of particular characters, so as to redress the flaws of the general public, and correct people through fear of exposure to ridicule.

16 Ilaria Crotti, "Il Carattere e il Baule" in Libro, Mondo, e Teatro: Saggi Goldoniani (Venezia: Marsilio, 2000).

17 Parola, Musica, Teatro, Scena. Percorsi nel teatro di Carlo Goldoni e Carlo Gozzi, a cura di Giulietta Bazoli e Maria Ghelfi (Venezia: Marsilio, 2009).

18 Siro Ferrone, La vita e il teatro di Carlo Goldoni (Venezia: Marsilio, 2011). 


\section{The foundations of musical comedy}

Goldoni began his activity as a librettist at an early age in 1730, first adapting existing texts for new musical settings, as for example Griselda, from a text by Apostolo Zeno (1668-1750), for Antonio Vivaldi (16781741). Goldoni then authored texts for short comic intermezzi, while his first dramma giocoso (La scuola moderna) was written in 1748, ten years after Momolo cortesan, the comedy that, according to the author himself, marked the first steps of his theatrical reform. It is significant to note that before Goldoni, the presence and popularity of the dramma giocoso in Venice are difficult to trace. Surviving documents give word of very few titles, the earliest of these being from 1744: La Libertà Nociva and L'ambizione delusa, neither of which have survived. Both were by Rinaldo di Capua with libretti written or readapted by Giovanni Barlocci, and both premiered at the $S$. Cassiano theatre, which, taking example from the already established $S$. Samuele and $S$. Moisè, began favoring comic opera in its programming given the growing popularity of this art. These remain, however, sporadic titles among a myriad of other, more prominent, musical genres: drammi seri, drammi berneschi, drammi eroi-comici, farces, divertimenti, and commedie per musica are just some of the many forms authors were experimenting with. Goldoni too, before La scuola moderna of 1748, essayed all of them without ascribing preference to any one genre over the others. After La scuola moderna, however, he would turn his attention almost exclusively to this newest form, the dramma giocoso per musica, and following his abundant production of these texts, examples surface throughout Europe in the work of subsequent generations, all the way to the Viennese school. These are the libretti Goldoni began writing only as a mature playwright, in other words as an established author with very clear ideas about his own artistic criteria and his agenda for the future of comic theatre. These are the libretti that went on to have a lasting impact on the history of opera. 


\section{i. The limits of opera seria}

In the dedication of his comedy Terenzio (1754), the Arcadian Polisseno Fegejo bows to the greatest man of modern theatre, Pietro Antonio Domenico Trapassi, better known as Metastasio (1698-1782):

In tutti i teatri d'Europa non si rappresentano che i Drammi vostri. Si replicano nel teatro medesimo le dodici, le venti volte. Non vi è compositore di Musica, che non le abbia sperimentate. Non vi è casa, non vi è persona, che non ne sia provveduta. Sono numerosissime le edizioni, e fortunati coloro che le hanno stampate. I Comici ancora se le sono appropriate per molto tempo, e con profitto notabile le hanno senza musica rappresentate. Da moltissime genti si sanno per la maggior parte a memoria, e pure si gustano sempre, piacciono ogni ora di più, e qualunque Dramma espongasi sulle scene, ha sempre un massimo disavvantaggio, se non è della felicissima penna del Metastasio. ${ }^{19}$

Fegejo, the 'pen name' of none other than our Carlo Goldoni, joined the Accademia degli Arcadi (founded in Rome in 1690 with 'colonies' throughout Italy) as Metastasio was fast becoming one of the greatest exponents of its second generation. To judge from his works, however, Goldoni seems to have appended his Arcadian name to comedies and libretti more as a stamp of prestige or an act of due homage than as a seal of fidelity to Arcadian poetic principle; the social critique and quotidian reality rendered so vividly in Goldoni's comedies and in many libretti could not be more distant from the philo-Classical and bucolic hues of Arcadian, and Metastasian, theatre.

Goldoni's Arcadian affiliation appears even more rhetorical as we recall that comedy and comic opera, while first relegated to the

19 Carlo Goldoni, Terenzio, Forward. In all the theatres of Europe we find none but your plays. They are given in the same theatre twelve, even twenty times. There is no composer of Music that has not tried them. There is no home, no person that does not possess them. Numerous are the editions, and lucky are those who have printed them. The actors too have made them their own, and with notable success have staged them without music. Many people know most of them by heart, and yet they are always enjoyed, they become ever more pleasing, and whatever Dramma be presented on the stage, it always suffers major disadvantage, if it does not spring from the felicitous pen of Metastasio. 
accompaniment of tragic plays or opera seria, began to take form as independent genres following their rejection by the Arcadian reform of Apostolo Zeno (1668-1750), consolidated by his pupil Metastasio. These poets endeavored to return opera seria to its ancient prestige and simplicity largely by purging it of all comic elements. Didone abbandonata (1724), Alessandro nell'Indie (1729), L'Olimpiade (1733), and La Clemenza di Tito (1734), but few in a long list of renowned titles, immediately testify how Arcadian, or better Metastasian opera (Trapassi's texts alone were the uncontested models of the melodramma serio), drew plots exclusively from ancient history and Classical mythology, an approach later replicated in the French tragédie lyrique (though for political rather than cultural reasons, as pagan gods became allegorical representatives of the reigning monarch and his court).

Seeking majesty rather than intrigue, Metastasian opera invested in arias at the expense of plot development, and was- much like Goldoni's earliest attempts- made up entirely of these solo pieces in alternation with versi sciolti, that is free recitative unbound by rhyme and meter, impositions that could corrupt their 'natural' quality. A central characteristic of this type of theatre is the da capo aria, which repeats opening text and music at its end to create a symmetrical structure, a form in other words very respectful of the then dominant neoclassical aesthetic of equilibrium and proportion.

Analysis of musical scores written on Goldoni's early drammi giocosi uncovers an initially substantial use of this traditional form, in alternation with recitative and little else- a surprisingly commonplace approach, but obviously expected from composers. Mozart's later operas, for that matter, use these structures as well. The point of distinction comes in the ever-decreasing proportion of traditional forms in Goldoni's more developed drammi giocosi and in later Mozart operas, in which ensembles, large and small, take over what was once solo recitative, and new, flexible, musical structures banish the stasis of traditional arias. The sparse use of da capo forms by the end of the $18^{\text {th }}$ century is proof that the very characteristics that made this musical form so desirable from an Arcadian perspective made it a hindrance for Goldoni and his successors. Goldoni, as a realist author, patiently chiseled out a more psychologically attuned theatre both in prose and in song, and the circular nature of the da capo form is not easily reconciled with 
plot development or emotional change. Clearly, the investment of many new authors in comic rather than melodramatic works in the mid- $18^{\text {th }}$ century was not only fueled by popular interest, but also and especially by critical instinct.

Goldoni's own output reflects with perfect clarity the shift from an initial effort to emulate tragic opera to an entirely opposite, personalized aesthetic and a search for new horizons. As any respectable student of law and the ancient authors, he commenced his theatrical career with high hopes of establishing himself as a tragedian of the purest Classical brand. His first texts were tragic operas, and his theatrical debut, the ill-fated Amalasunta, was written 'according to all the laws of Aristotle and Horace,' "per la quale," Goldoni writes, "avea spogliato bastantemente la Didone e 1'Issipile di Metastasio." ${ }^{20}$ Yet despite having 'borrowed' from the most prestigious sources on that occasion, Goldoni's aristocratic advisors (the Milanese Count Prata and his circle) saw a text beyond repair- one that violated too many good principles of tragic theatre. For Amalasunta it was a death sentence, and our author, many years later, would describe the scene in vivid tones: "Non potea più contenermi, mi levai con un movimento involontario, violento, gli chiesi scusa, lo ringraziai de' suoi amichevoli avvertimenti, e conclusi dicendo che, scandalizzato dalla regole del Dramma, facea proponimento di non comporne mai più." ${ }^{21}$ His tragedy traveled from the hands of his Milanese readers to the fireplace of Goldoni's lodging in town, a sign that his calling lay elsewhere.

The concurrent decline of opera seria was gradual and by no means uniform, but already detected early in the century. Metastasio continued to produce libretti until 1740, yet Il Teatro alla Moda, an exquisite satire of opera seria by the Venetian Benedetto Marcello (1686-1739), was already in print by 1720 . Marcello's commentary is a prime witness to the incompatibility of this dominant theatre with any measure

20 Carlo Goldoni, Memorie Italiane (Prefazioni ai Diciassette Tomi delle Commedie edite a Venezia da G.B. Pasquali [1761-1778]), tomo X. (...) for which I had sufficiently robbed Dido and Issipile by Metastasio.

21 ibid., tomo XI. I could no longer restrain myself, I stood with an involutary, violent motion, apologized, thanked him for his friendly warnings, and concluded by saying that, scandalized by the rules of Opera, I resolved never to write any again. 
of verisimilitude, Goldoni's golden standard. For instance, vocal display appears by historical accounts to have nearly bordered with sportsmanship. Audiences, who typically enjoyed food, drink, and conversation while the operas were performed, tuned in most unanimously during the da capo arias to marvel at a performer's vocal ability and judge his or her virtuosic ornamentations. This was the economy that gave rise to the famous aria di baule: 'trunk arias' tailored to vocalists' individual abilities and bluntly inserted in substitution of an original aria, often with scarce relation to the surrounding action- an indifferent divorce from scruples of dramatic coherence that lent Benedetto Marcello more fuel for his pen:

Si lamenterà sempre della Parte, dicendo che quello non è il suo fare, riguardo all'Azione, che l'Arie non sono per la sua abilità, etc., cantando in tal caso qualche Arietta d'altro compositore, protestando, che questa alla tal corte, appresso il tale Gran Personaggio (non tocca a lui dirlo) portava tutto l'applauso, e gli è stata fatta replicare sino a diciassette volte per sera. ${ }^{22}$

Obviously these 'trunk arias' needed to keep generic language to be less at odds with surrounding material in a plurality of contexts. The awkwardness of dense virtuosic display over thin poetic content was in fact the hallmark, for a sarcastic Marcello, of the fashionable melodramatic aria:

Dovranno formarsi tutte le Canzonette delle medesime cose, cioè di Passaggi lunghissimi, di Sincope, di Semituoni, d'alterazioni di Sillabe, di repliche di parole nulla significanti, v.g. Amore Amore, Impero Impero, Europa Europa, Furori Furori, Orgoglio Orgoglio, etc. ${ }^{23}$

22 Benedetto Marcello, Il Teatro alla Moda, “Al Musico.” He will always complain about his Part, saying that it is not his doing with regards to the Action, and that the Arie are not for his abilities, etc., in that case singing instead an Arietta by a different composer, protesting that this piece, at such and such court, under such and such Great Eminency (whom it is not his place to mention), brought all the applause, and up to seventeen encores in a single evening were requested of him.

23 ibid., "Al Poeta." All the little songs must be made up of the same things, that is very long Passages, Syncopations, Semitones, alterations of Syllables, repetition of meaningless words, e.g. Love Love, Empire Empire, Europe Europe, Rage Rage, Pride Pride, etc. 
In sum, the stasis of traditional melodramatic forms, together with the theatrical incongruence of decadent opera seria, prepared fertile ground for a more rational, socially attuned comic alternative. While Metastasio continued to acquire the fame and diffusion that we read of in Goldoni's Terenzio, from a critical point of view, what he sought in purity carried the risk of becoming sterile. In its development, comic opera therefore turned away from the predominating theatre and drew from vastly different sources.

\section{ii. Naples and the commedia per musica}

Having glimpsed the theatrical world in which comic opera was introduced, we can now trace its evolution outside the walls of opera seria so as to better understand, in turn, the new direction taken by Goldoni. First, however, we must carefully weigh the notion that comic opera was but nascent after the Arcadian reform. Some scholars date the birth of comic opera to the $16^{\text {th }}$ century, with Il Cicalamento delle Donne al Bucato (the Chatter of Women at the Wash) by Alessandro Striggio the elder (1536-1592), principal court musician under Cosimo de' Medici, whose homonymous son would later compose the libretto of Monteverdi's famous Orfeo. Il Cicalamento has been called a 'madrigal comedy,' and does not present a unified action in the manner of true opera, but rather a series of ordered madrigals that narrate a sequence of events.

The Venetian environment in particular appears to have had a preferential affiliation with comedy rooted in times far preceding Goldoni. Il Candaule (1679), dramma per musica by the librettist Adriano Morselli (dates unknown) that revisits the ancient Anatolian kingdom of Lydia; L'Alcibiade (1680), titled after the ancient Athenian commander and fictional protagonist of a presumed early platonic dialogue, dramma per musica by librettist Aurelio Aureli ( 1650?-1710?) of the Accademia degli Imperfetti, with music by Marc'Antonio Ziani ( 1650?-1715), maestro di cappella under Ferdinando Gonzaga in Mantua and later under Leopold I in Vienna; and Messalina (1680), from a text by Francesco Maria Piccoli (dates unknown) and music by Carlo Pallavicino 
(1630-1688) of the Venetian Ospedale degli Incurabili, are all forms of 'alternative' musical theatre predating the $18^{\text {th }}$ century.

Another survivor from this period is La Semiramide (1671), later to reappear in Venice as La Schiava Fortunata (The Lucky Slave, 1674), employing traditional comic devices such as disguise and role reversal. This originally Florentine work, commissioned by prince Leopoldo de' Medici and created by court doctor and "poeta teatrale" Giovanni Andrea Moniglia (1625-1700) with music by Antonio Cesti (1623-1669), draws comic techniques from Calderón de la Barca (1600-1681), creating intrigue from the physical resemblance of Semiramide to her son Nino, which permits character swapping and dramatic irony. In keeping with the Seicento tradition launched by L'Orfeo, all of these works are set in remote times, and feature ancient protagonists. One could hardly suppose that enlightened comic opera should draw its roots from them. Indeed, in the same decades but far south in Naples, aristocrats and workers alike were already enjoying an entirely different type of musical theatre that elected realism above exoticism.

Neapolitan comic theater of the late $17^{\text {th }}$ century grew from direct contact with popular and dialectal culture, enriched by the local traditional song in llengua napolitana. The lyrical canzone napoletana, still heard today and still intimately tied to its dialectal roots, acquired a dramatic dimension. In the first decade of the 1700s, (particularly 1700-1707), the latest fashion in entertainment appears to have been the scherzi drammatici e scenici, staged in aristocratic homes as well as public piazzas. A hybrid between melodramma and popular tradition, they adapted recitative and arias to the use of dialect, and employed buffo and serio characters together. One such work, given in Naples in 1701, was Il Mondo Abbattuto (The World Demolished), scherzo scenico by Michele de Falco ( 1688- 1732?) and Nicola Sabini ( 1675?-1705), a composer of popular canzoni. He exemplifies how the musicians who wrote popular music were the same who created these more 'refined' scherzi- and not all were professional musicians or playwrights. The first known Neapolitan commedia per musica, La Cilla (premiered on 26 December 1707 at the residence of the prices of Chiusano) was written by two jurists, Francesco Antonio Tullio (1660-1737) and Michelangelo Faggiuoli (1666-1733). Their alternative professional affiliation may have lent a certain license to bend the rigid musical customs that 
traditional court composers would have been bound to. Together with librettists Francesco Antonio Tullio (1660-1737), Giovanni Veneziano (better known as Agasippo Mercotellis, 1683-1742), Carlo de Petris (dates unknown), Nicola Gianni (dates unknown), Bernardo Saddumene (dates unknown), and others, the composers who contributed to the new comic genres are numerous, among them Faggiuoli, Michele de Falco, Benedetto Riccio (dates unkown), Francesco Antonio Scarlatti (1666- 1741?), and Antonio Orefice ( 1708?- 1734?). Orefice would become a key figure in the development of musical comedy up until the end of the 1720s, composing not only for works in dialect but also for comic, tragic, and tragicomic operas in Italian (e.g., Chi la dura la vince (He Who Withstands Prevails), 1721).

The most eye-catching element of affinity between this early Neapolitan musical comedy and Goldoni's later works is a renewed emphasis on the populace and on everyday life; the commedia per musica, unlike the few aforementioned comic operas of the Seicento produced in northern Italy, was a realistic musical genre. Not foreign lands or distant times but different neighborhoods of Naples are the chosen settings, and similarly, the action is not extravagant but rather sketches daily life. Castrati were excluded and performers of both sexes were used for greater realism.

Interestingly, Paolo Gallarati has suggested that the simplicity of the Neapolitan commedia per musica was motivated by the same anti-Baroque sentiments that gave rise to the Arcadian reform: "Liperbole straniante del barocco viene quindi accantonata in quest'arte a misura d'uomo [la commedia per musica], nata dalla stessa esigenza di semplificazione che ispirava il movimento $\operatorname{arcadico}(. .$.$) ; un moto$ di rinnovamento che determinerà, pochi anni dopo, l'affermazione del teatro metastasiano." 24 Clearly, this common philosophical ground, perhaps shared originally, does not produce any affinity of content between the two types of theatre- one representing an idealized past, the other anchored in the present- though some scholars have supposed

24 ibid; 109. The alientaing hyperbole of the Baroque is thus put aside in this art of more human proportion, born from the same desire for simplification that inspired the Arcadian movement (...); an impulse of renewal that will determine, a few years later, the rise of Metastasian theatre. 
Metastasio to have been familiar with Neapolitan comedy, and to have derived the simplicity of his language and the harmony of his verses from this model..$^{25}$

A no less important element of affinity between Neapolitan and Goldoni's own musical comedies is the intended audience. While opera seria was still the domain of aristocratic audiences, the commedia per musica was appreciated by the nobility as well as by the working class. We know this from accounts of the premiere of La Cilla, given for a mixed audience. In those particular circumstances, changes at the governmental level may have played a key role, in particular as, in 1707, the Venetian diplomat and later cardinal Vincenzo Grimani (1652-1710) was made viceroy of Naples. An ally of the Hapsburgs, Grimani at the head of local government represented a break from Spanish domination. Coincidentally Grimani, himself a librettist, was also the owner of the Teatro San Giovanni Grisostomo in Venice, where his operas were performed and where, most importantly, Goldoni would later serve as director (1737-41), presenting the comedy often cited as the herald of his reform, Momolo cortesan (Momolo the courtier).

Grimani's cultured appreciation for musical theatre likely encouraged the proliferation of the commedia per musica in those early years. In its first phase, the great and rapid development of the commedia per musica was largely stimulated by the patronage of the Neapolitan nobility. Predictably, many early commedie per musica that bear the names of local noblemen in dedication. Yet how can we understand the willingness of the higher class to sponsor the development of a theatre that was written outside the courts, and that was popular in content and style? The key may lie again in political context, particularly in the use of local vernacular as a means of preserving cultural identity. For Paolo Gallarati, “L'uso del vernacolo(...)non ne prova un'origine popolare, ma va piuttosto interpretato come il rifiorire di una tradizione culturale indigena opposta a quella straniera dei dominatori, prima spagnoli e poi austriaci, a partire dal 1707; tanto che gli autori appartenevano in maggioranza al ceto forense del cosidetto popolo civile, portatore

25 See Alberto Basso et al., Musica e scena. Storia dello spettacolo musicale vol. IIII (Torino: UTET, 1998), and Roberto Zanetti, La Musica Italiana nel Settecento, vol. 1 (Busto Arsizio: Bramante Editrice, 1978.). 
delle nuove istanze della cultura preilluministica." ${ }^{26}$ The connection of commedia librettists to nascent Enlightenment ideals, thanks to their professional exposure as jurists- a profession shared by Goldoni himself- adds a further link (by no means the last, as we shall see) from Neapolitan comedy to our author.

To this we add that just as the composers of commedie per musica were also creators of traditional Neapolitan song, and infused one music with the style of the other, the librettists of these musical works were often authors of dialectal prose comedies (commedie d'intreccio e di carattere, or 'character comedies'), fully imbued in the native tradition that boasted novelle (short stories), poemi (epic poems), and drammi pastorali (pastoral plays). A similar interconnection characterizes the entirety of Goldoni's output, and is the foundation of the present study. The close relationship of opera texts to prose comedy is exemplified by Patrò Calienno de la Costa (by Mercotellis and Antonio Orefice), a musical comedy drawn closely from La Perna, prose comedy in dialect written by the attorney Nicola Corvo. Patrò Calienno launched the first season of the public Teatro dei Fiorentini in 1709, marking a turning point in history. Written in Neapolitan dialect, Patrò Calienno is the earliest known psychological comedy that puts the world of its spectators onto the stage. From a technical point of view, too, it foreshadows future Goldonian traits. In particular, the commedia per musica refused the tendency of tragic opera to separate arias from the rest of the action, placing them centrally within scenes, unlike the traditional aria d'uscita (exit aria).

A final, and fundamental commonality between this Neapolitan genre and Goldoni's later works is an increasing reliance on ensemble pieces, which undergo significant development with respect to opera seria. The greater dramatic space occupied by ensemble scenes, especially in music but also at times in prose comedy, is the product of a

26 Paolo Gallarati, Musica e Maschera; 108. The use of the vernacular (...) does not prove its popular origin, but should be interpreted as the renaissance of the local culture, in opposition to that of foreign domination, first Spanish then Austrian, beginning in 1707; so much so that the authors were in large part members of the judiciary class of the so-called civil society, harbinger of the new demands of pre-Enlightenment thought. 
new criteria for imitative, realistic theatre, that can depict social interaction with vivid color and veracity. In the early commedia per musica, polyphonic ensembles were often used, for example, to evoke the bustling and chatter of crowded public spaces, such as a town piazza. In other words, these pieces did not affect the main action, but served an evocative role. Yet, it is from this foundation that Goldoni would later develop ensembles that carry intrigue, employing four or more characters simultaneously no longer as functional background but center stage. An attractive asset of mature ensemble pieces is their ability to juxtapose different emotions (rage, hope, sadness, surprise, tenderness), a hallmark of Goldoni's drammi giocosi as of later Mozartean opera. Interestingly, the so-called "ensemble finale," appears in his best prose comedies as well.

To return to the commedia per musica at the Teatro dei Fiorentini, it is important to know that while this venue initially offered a mix of musical comedies and more traditional melodrammi (by minor authors, however, rather than by Metastasio), the same impresario- a certain Nicola Serino- would, at a later stage, decide to specialize the theatre exclusively in commedie per musica. This theatre therefore became the first center of what would later be opera buffa, opening to an even broader audience after 1714 (following a damaging fire and rebuilding) with old and new works by Nicola Corvo (dates unknown; Patrò Calienno de la Costa, Lo 'mbruoglio de li nomme, 1711, Patrò Tonno d'Isca, 1714), Nicola Gianni (dates unknown; L'alloggiamentare, premiered 1710), and by Francesco Antonio Tullio (dates unknown; Li vecchie coffejate, 1710, La Cianna, 1711, and Lo finto Armenejo 1717), among others.

The success of the commedia per musica at the Teatro dei Fiorentini encouraged other theatres in Naples to present these works, and within a few years these musical comedies arrived at the Teatro Nuovo and the Teatro della Pace, ever more appreciated by audiences. An opera worthy of note that belongs to this second phase of the commedia per musica is Li zite ' $n$ galera (The Spouses in Prison), by Bernardo Saddumene (dates unknown), given at the Teatro dei Fiorentini in 1722 with music by Leonardo Vinci (1690-1730), then modified and represented at the Teatro della Pace in 1724, newly opened thanks to growing public interest in comic opera. This work is particularly relevant to a study of 
Goldoni's musical texts because it bears clear signs of evolution with respect to earlier musical commedie. In particular, in $\mathrm{Li}$ zite ' $n$ galera we find ensemble arias both within scenes as well as at the end of acts, a dramatic technique that will soon become the signature of Goldoni's libretti and of fully formed opera buffa. To cite only one example, the second act contains a famous trio that presents pert dialogue, not in declamatory style, but in an almost conversational (and given the romantic rivalries, sparring) tone, yet not without pathetic accents:

BELLUCCIA. Fortuna cana, o Dio,

dimme che te facc'io!

CARLO. Amore tradetore,

che buò da chisto core?

CIOMMA. Destino mio teranno,

levame da st'affanno.

A TRE. Quanno la vuò scompì!

CARLO. Bellezza de sto core.

BELLUCCIA. Facce de tradetore.

CIOMMA. Tu sì la morte mia.

CARLO. Che t'aggio fatto.

CIOMMA. Abbìa.

BELLUCCIA. Carlo non te partì.

CIOMMA. E lassannillo ì.

CARLO. Tu mme vuò fa' impazzì. ${ }^{27}$

With Li zite ' $n$ galera, we begin to perceive a measure of distinction between character types which will later evolve into parti buffe, parti serie, and mezzi caratteri. The differences in style and content brought by this division of roles, expanded and fully established by Goldoni, will become his single greatest contribution to comic opera, along with a clear progress towards the inclusion of sentimental strains. Zanetti has perceptively suggested that in Neapolitan opera (but not later comic opera), sentimentalism is derived from the nostalgic vein of traditional

27 Bernardo Saddumene, Li zite 'n galera, Act II. (Belluccia: Oh Fortune, o God, tell me, what have I done to you? Carlo: Traitorous love, what do you want from this heart? Ciomma: Tyrannous destiny, release me from this torment. Tutti: How I wish I could prevail! Carlo: Beauty of this heart. B: Traitor-face. Ciomma: You are the death of me. Carlo: What have I done to you? Ciomma: Go away. B: Carlo, don't go. Ciomma: Let him go. Carlo: you want to drive me out of my mind. 
folk songs that formed other aspects of the genre. ${ }^{28}$ Undoubtedly, sentimental depth is developed more extensively as differences between buffo and serio roles become more affirmed; often, in mature comic opera, the entire intrigue will develop from the social disparities between characters alone. In testimony of the dramatic potential afforded by the contrast of roles, we must recall that it was not uncommon for comic and serio roles of the same work to be set to music by different composers, a practice applied to some of Goldoni's texts as well.

As the commedia per musica established itself with success in the major theatres in Naples, it began to engage visiting actors from other regions of Italy (initially professional actors also performed in musical roles, while professional vocalists reserved their talents for opera seria), and its fame began to spread north. With the arrival of Italian actors from outside Naples, librettists such as Bernardo Saddumene, Niccolò Corvo, and Francesco Antonio Tullio were among the first to begin to soften the strong dialectal stamp of their works, alternating local speech with parts in Italian, or better, Tuscan, performed by the visiting actors. A universal or 'standard' Italian, quite measured in comparison to the quick cadences of dialect, and untainted by local color, lent itself more credibly to roles of a certain gravity, and gradually became the expected mode of expression for characters of higher social status. As this tendency consolidated into common practice, the use of dialect was in turn limited to characters of popular extraction, the most spontaneous source of comic play (and the most concrete link to the Commedia dell'Arte). Without doubt, this linguistic division contributed significantly to the explicit distinction between serio and buffo roles, increasingly apparent in the libretti of Gennaro Antonio Federico (birth unknown-1744), Pietro Trinchera (1707-1755), and Antonio Palomba (1705-1769).

The 'contamination' of Neapolitan dialect with Tuscan properly began in the 1718 season, with the staging of Il gemino amore (The

28 Roberto Zanetti, "La commedia musicale" in La Musica Italiana nel Settecento, vol. 1 (Busto Arsizio: Bramante Editrice, 1978.); 283. "Il nucleo originario di questa disposizione, dovuta a una naturale vena elegiaca e di soffusa malinconia, deriva alla commedia direttamente dal mondo della canzone popolare." (The original nucleus of this disposition, owed to a natural elegiac vein and delicate melancholy, derives to comedy directly from the world of popular folk song). 
Twin Love) and of Il trionfo dell'onore (The Triumph of Honor; texts by Tullio, music by Orefice and Alessandro Scarlatti (1660-1725; Il trionfo is in fact his only comic opera)). Their Italianate titles alone indicate a significant change from works such as Lo 'mbruoglio de li nomme (The Mix-up of Names) or Li zite ' $n$ galera, and are indicative of a new outlook, and a new envisioned role for the commedia per musica. Essentially, the Italianized commedia per musica was opening to a broader bourgeois audience in anticipation of circulation beyond Naples, and well before the mid $18^{\text {th }}$-century consolidated into an enticing alternative to opera seria well beyond its hometown.

Its first arrival in Venice can be precisely dated to 1711, when a visiting Neapolitan poet, Domenico Lalli (1679-1741; known by the pen name Sebastiano Biancardi), brought materials from home to stage in theatres on the lagoon. His musical comedy L'Elisa, based on an earlier text from 1699 and set to music by the Veronese Giovan Maria Ruggieri ( 1665?- 1725?), was given at the same Teatro S. Angelo where Goldoni would later stage his own comedies.

Authors were far from the only conduits of Neapolitan musical comedy, however. Musicians and visiting composers also become conduits of this new alternative theatre, and the uncontested dominance of the Neapolitan school in composition is clearly reflected in the long list of notable exponents who set Goldoni's drammi giocosi, Goldoni collaborated with a long list of Neapolitan composers. Gioacchino Cocchi (1720-1804), with whom Goldoni wrote La mascherata (The Masked Lady) and Le donne vendicate (The Avenged Women) in 1751, for example, returned to Naples immediately following this collaboration in Venice and composed for the Teatro Nuovo, his operas soon an international success. Vincenzo Legrenzio Ciampi (1719-1762), who set to music Goldoni's first dramma giocoso, La scuola moderna (The Modern School, 1748), along with Bertoldo, Bertoldino, e Cacasenno (1748), Il negligente (The Negligent, 1749), and Amore in caricatura (Love in Caricature, 1761), was not Neapolitan by birth but pursued his studies there from a young age, and therefore was also fully formed in that tradition. Niccolò Piccinni (1728-1800), who would become one of Goldoni's principal composers after the retirement of Baldassare Galuppi (from 1766 onwards), was also from Naples. The list of Neapolitan contemporaries continues with Giuseppe Scarlatti $(\sim 1718 ?-1777)$, born and 
trained in Naples, who wrote music for I portentosi effetti della Madre Natura (The Prodigous Effects of Mother Nature) given at the Teatro San Samuele in 1752, and later De gustibus non est disputandum (No Dispute About Taste (from a Latin proverb) premiered at the Teatro San Cassiano, 1753), Il mercato di Malmantile (The Market of Malmantile, premiered at the Vienna Burgtheatre, 1757), and L'isola disabitata (The Deserted Island, Teatro San Samuele, 1757); with Domenico Fischietti (1725-1810), also Neapolitan and an imitator of Galuppi's style, and first composer (now overshadowed by Franz Joseph Haydn) for Lo speziale (The Apothecary, 1768), La ritornata di Londra (The Returned from London, 1756), Il mercato di Malmantile (collaborator, 1757), Il signor dottore (The Doctor, 1758), La fiera di Sinigaglia (The Fair of Sinigaglia, 1760), and La donna di governo (The governess, 1763); and finally with Giuseppe Scolari ( 1720? - 1774?), collaborator from 1756-58 for La cascina (The farmstead, 1756), a second rendition of Il Conte Caramella (Count Caramella, 1756), Le nozze (The Wedding, 1757), Le donne vendicate (1757), Il viaggiatore ridicolo (The Risible Traveler, 1762), Il ciarlatano (The charlatan, 1759), and a second production of La buona figliuola maritata (The Good Girl Married, 1762), originally set to music by Piccinni, and revised for the theatre in Murano. Composers of Neapolitan origin are important figures in the transmission of the commedia per musica not only because of their musical experience, but most importantly because, during their time in Naples, they partnered with Neapolitan comic librettists and worked on productions for the same theatres in which comic opera first claimed attention. The level of interaction between Goldoni and these composers is not documented, but being all contemporaries of the author, one can assume at the very least that they were familiar with each other's work.

In 1743, Venetian theaters presented two famous Neapolitan operas: La finta cameriera (libretto by Giovanni Barlocci) given at the Teatro S. Angelo during the Fiera dell'Ascensione, and shortly thereafter Madama Ciana (libretto by the same Barlocci). Both were set to music by the Neapolitan Gaetano Latilla (1711-1788, uncle of Piccinni), who, interestingly, also set many Metastasian tragedies. The latter, Madama Ciana, was modified from its original setting by Baldassare Galuppi, Goldoni’s first collaborator. Galuppi, affectionately 
known as "Il Buranello" because he was born and raised on the Venetian island of Burano, is one of few composers Goldoni interacted with to have studied in Venice and not in Naples. Notwithstanding, it is clear that Galuppi, too, was quite familiar with the styles and structures of Neapolitan opera. We thus begin to understand how dense and numerous are the interconnections between the theatrical and musical worlds of Naples and Venice.

\section{iii. Venice and the intermezzo}

The commedia per musica did not, however, constitute the Venetian spectator's only choice. In the years following the arrival of Neapolitan works in Venice, theatres also produced a myriad of drammi comici, divertimenti giocosi, opere bernesche, and other ephemeral forms. Only with Goldoni are these variants compounded and canonized into a universal operatic genre, a 'unifying model on a national scale'29 that will endure through the next generations and far outside of Italy. Furthermore, the manifold documented connections between Goldoni and Neapolitan composers, and the popularity of the commedia per musica in Venetian theatres, do not imply that Goldoni's drammi giocosi developed from this tradition alone. Part of Goldoni's achievements in musical theatre must also be understood as the product of his expansion of the intermezzo, a genre in origin quite opposite to the Neapolitan commedia, with which Goldoni began his musical career.

Goldoni was a practical connoisseur of both the Venetian intermezzo and the Neapolitan commedia traditions. His contributions to comic opera, therefore, cannot be credited to any single influence, but to a combination of complementary trends, of which the commedia per musica is perhaps the least well-known (and for this reason we have traced its history in some detail). These are the premises that will push

29 Paolo Gallarati, Musica e Maschera; 127. "un modello unificante su scala nazionale." 
Goldoni to experiment and expand his texts for music up to the achievement of the dramma giocoso.

With respect to the similar currents that shaped the development of art forms in both northern and southern Italy, it is worth recalling that, by the 1730 s, the two most important Italian pioneers of comic musical theatre were Giovanni Battista Pergolesi (1710-1736) from Iesi (then part of the papal states), composer of the famous La Serva Padrona (The Servant Master, an intermezzo no less) that traveled to the corners of the world, and our Venetian Goldoni, who in the same years created the intermezzi we will now examine. At different ends of the Italian peninsula, both authors were drawn to complementary ideals of realism and of bourgeois society, and each gave form to these as he knew best.

According to Gian Giacomo Stiffoni, ${ }^{30}$ intermezzi existed in Venice a good twenty years before Goldoni began to write his own. These rather peculiar vocal divertissements began to take shape in their own right following the famous reform of Zeno and Metastasio. In the effort to restore il buon gusto (good taste) to opera seria through a process of purification, comic elements were exiled and relegated to the intermezzo, a simple, separate plot given between acts of the main work, as a breath of comic relief.

The first official recognition of the intermezzo as an emancipated type of musical theatre comes in 1706, when, for the first time, a pamphlet entitled Nuovi intermedi per musica circulates a collection of texts without the opera seria libretti they would have usually accompanied. Pietro Pariati (1665-1733) is the best known author of intermezzi in their first Venetian season of 1706-1709, and his libretti, set to music by notable composers such as Francesco Gasparini (1668-1727), Antonio Lotti (1667-1740), and Tommaso Albinoni (1671-1751), were among the first to be printed. For Reinhard Strohmm, the 1706 edition is a clear sign of the 'social emancipation of the comic genre in opera.' ${ }^{31}$ Among Pariati's first known titles are Erighetta e don Chilone (1707) and Pimpinone

30 Gian Giacomo Stiffoni, "Introduzione" in Carlo Goldoni, Intermezzi e farsette per musica, a cura di Anna Vencato (Venezia: Marsilio, 2008).

31 ibid.; 11. (...) “l'emancipazione sociale del genere comico nell'opera." 
(1708). Unfortunately, large part of this early production, given at the Teatro S. Angelo and the Teatro S. Cassiano, has since been lost.

General characteristics of the intermezzi are their structural simplicity and- all-important quality- the economy of means they require to be performed. Typically formed in two acts (rarely three), the entire action is spun from the conflict between two characters, usually a soprano and bass, serva and padrone (servant and master). From the few musical scores of early intermezzi that have survived we know the instrumental ensemble was also quite basic, a small group of string players being sufficient to support the whole work. These musical spoofs are most readily associated with a caricatured type of funniness, with disguises, verbal absurdities and neologisms, bizarre foreign characters, and racy gesturing; verisimilitude was never a primary concern of the intermezzo. Musically, these works are very simple in both construction and style: simple recitative and a solo aria for each character in each act, culminating in an 'ensemble finale' of two. Language and terms could be quite quotidian, but the structure of the arias hailed back to the closed forms of opera seria, using the tripartite da capo structure (ABA') or an expanded variant (pentapartite AA'BAA').

For their simplicity, and for their economy, intermezzi were soon exported. For example, the Raccolta copiosa d'intermedi, parte da rappresentarsi col canto, alcuni senza musica con altri in fine lingua Milanese (Copius Collection of Intermezzi, some to be performed with song, some without music, and some in fine Milanese) printed in Milan in 1723, lists fifty-four different titles. Research has dated their arrival in Naples to around 1715, and this southern capital, notwithstanding its own comic musical tradition, soon became a center of diffusion and exportation in turn. As previously mentioned, the most famous intermezzo of all time, La serva padrona (1733), originally created to accompany a tragic opera, Il prigioner superbo (The Proud Prisoner), but soon a stand-alone piece, was composed by Pergolesi, an eminent exponent of the Neapolitan school. 


\section{New directions}

\section{i. Goldoni’s apprenticeship with musical texts}

By the time Goldoni was a young man, intermezzi appeared in virtually all of Venice's thirteen theatres, with the exception of the more prestigious Teatro San Giovanni Grisostomo (today still working as the Teatro Malibran) which, to offer more lavish spectacle, housed ballets and opera seria exclusively. Goldoni wrote his first intermezzi in Feltre in 1729 for a local dilettante theatre company. These were naturally intended for placement between acts of an opera seria. The first, Il buon vecchio (The Good Sage), is now lost, while the second, La cantatrice (The Signer), is still attributed to Goldoni but was famously plagiarized by others. Goldoni writes,

Perduto ho poscia intieramente il primo intermezzo, per la poca cura ch'io avea delle cose mie; ed avrei perduto anche il secondo ma è stato esso da qualchedun conservato e l'ho veduto qualch'anno dopo rappresentare a Venezia col titolo della Pelarina...l'intermezzo riuscì in Venezia felicemente e altri se ne avea fatto merito e ne avea ricavato non poco utile... ${ }^{32}$

That 'other' discreetly mentioned by Goldoni is Antonio Gori, comic author and lawyer who openly asserted his own authorship of the intermezzo when it was given at the Teatro Grimani di S. Samuele in 1734 (the year of La serva padrona) under the direction of Giuseppe Imer (1700-1758), with music (now lost) by Giacomo Maccari. In the same

32 Carlo Goldoni, Memorie Italiane (Prefazioni ai Diciassette Tomi delle Commedie edite a Venezia da G.B. Pasquali [1761-1778]), tomo IX. I had then completely lost my first intermezzo, for the scant care I had of my things; and I would have lost the second, too, had it not been preserved by somebody, and I saw it given in Venice a few years later under the title La Pelarina(...)the intermezzo had a good success in Venice, and someone else had taken credit and had drawn from it no small profit (...). 
year, Goldoni began his important collaboration with Imer, and recalls Gori burning all bridges with the theatre company soon thereafter. To make the matter more complicated, the ubiquitous Venetian editor Antonio Groppo, in his Catalogo purgatissio di tutti li drammi per musica recitatisi ne'teatri di Venezia (Purged Catalog of all of the drammi per musica performed in Venetian Theatres) published in 1741, credits the work in question to a third author, the Florentine Giovanni Battista Fagiuoli (1660-1742). In any case, scholarship has widely accepted $L a$ pelarina (The Peeler [of Money]) to be Goldoni's first surviving intermezzo, and it appears in various historical editions of his works, among them the Tevernin and Zatta.

La pelarina (we revert to this title as the original La cantatrice, following Goldoni's account, no longer exists) is an exemplary intermezzo. The three characters, Pelarina, her mother Volpiciona ('BigFox'), and the avaricious Tascadoro ('GoldPocket') each sing two or three closed arie over the course of the work, and come together at the end of scenes to form a trio. Volpiciona's aria, "Sento che tutto in lagrime," strongly suggests a parody of opera seria, and the work mixes Italian with Venetian dialect. In Venetian Goldoni also wrote I sdegni amorosi tra Bettina putta de campielo e Buleghin barcariol venezian (The Amorous Disputes between Bettina the Venetian girl and Buleghin the Venetian boatsman, 1732), later revised as Il gondoliere veneziano (The Venetian Gondolier), for the Teatro Ducale in Milan during a brief stay in the city. Of this intermezzo, Goldoni writes,

(...)questo è il primo mio componimento ch'io ho lavorato pe' comici ed il primo che ho esposto al pubblico, pria sulle scene e poi sulle stampe. Picciola cosa, è vero, ma come da un picciolo ruscelletto scaturisce talvolta... Scusatemi, leggitori carissimi, ho la testa calda." ${ }^{33}$

Buleghin is a gondolier with a penchant for gambling, a vice explored in more than one of Goldoni's comedies, most famously in La Bottega del Caffè (The Coffee Shop, 1750). To judge from his own accounts, this

33 ibid., tomo XI. This is the first composition I crafted for the comic actors and the first I presented to the public, first in the theatre and then in print. True, it is but a trifle, but just as from a small stream at times flows forth... forgive me, dear readers, I am hot-headed. 
particular flaw of 'modern' society was looked upon by our author with a particularly sensitive eye thanks to some colorful first-hand experiences. In his autobiographical writings in fact Goldoni narrates how he was robbed at gunpoint (pistolpoint, that is) by a stranger from Padua who had cheated him at cards. This memory would stay with him, such that "nelle mie Commedie non mi sono scordato del mio Padovano, e di là ebbe origine quella collera con cui mi sono scagliato contro del gioco nella mia Commedia Il giocatore (The Gambler), nella Bottega del Caffè ed in altre, nelle quali ho avuto occasion di parlarne." ${ }^{34}$ Aside from affording an amusing biographical anecdote, Goldoni's personal experience evoked through his theatre reveals, firstly, a young author's innate interest in representing events and issues of contemporary relevance notwithstanding the dictates of the predominating musical fashion which largely preferred other subjects, and most importantly, the implicit belief that comic theatre, however entertaining and lighthearted, is not without the ability to target and stigmatize social problems ("mi sono scagliato contro del gioco," etc.).

As previously mentioned, following Il gondoliere veneziano Goldoni begins his career as an author, in 1734 at the Venetian Teatro Grimani. The theatre was home to a company of actors who recited prose tragedies, comic canovacci, but also sang comic intermezzi- at what level of skill, we do not know. Goldoni became acquainted with their capocomico, Giuseppe Imer, through a mutual friend (Casali) whom he chanced to rediscover in Verona performing in the famous Arena. Goldoni auditioned (as an author) reading portions of his early tragedy, $I l$ Belisario (1734), and this became his first work that Imer, the "direttore e quasi dispotico della Compagnia," 35 put into production. The tragedy enjoyed success and was appreciated for the realism with which it was written, as Goldoni recalls,

34 ibid.; tomo IX. In my comedies I never forgot my friendly Paduan, and there was the origin of the fierceness with which I hurled myself against gambling in my Comedy Il giocatore, in La Bottega del Caffe, and others, in which I had the chance of treating the subject.

35 ibid.; tomo XI. director and almost despot of the company. 
La Tragedia è andata alle stelle. Piacque in essa l'interesse, la verità e la condotta. Io faceva parlare l'Imperatore ed il Capitano come parlano gli uomini, e non con linguaggio degli eroi favolosi, al quale siamo avvezzati dalle penne sublimi de' valorosi Poeti. Volendo io esprimere un sentimento, non ho mai cercato il termine più scelto, più elegante, o sublime; ma il più vero ed il più esprimente. Veduto ho per esperienza che la semplicità non può mancar di piacere. Non intendo, quando dico semplicità, di far parlare un Imperatore come parlerebbe un pastore; ma intendo di non far parlare i Sovrani, uomini come noi, con un linguaggio incognito alla Natura. ${ }^{36}$

Goldoni's perception of his tragedy's positive reception as connected to its realism is a conclusion drawn in later years, which however shows that, from early on, Goldoni used the established customs of contemporary theatre as a springboard to give space to his own instinct. The same instinct that refused the stiff declamatory style of tragic theatre also took issue with coeval comedy, and Goldoni, impatient and eager to prove himself in new contexts, began trying his hand at texts for music:

Correvano altresì su quelle scene d'allora alcune Commedie, dette di carattere, come il Conte Pasticcio, il Don Chisciotte, la Maestra di Scuola, lo Smemorato, il Paroncino, il Prepotente, il Servo Sciocco ed altre in buon numero; ma i caratteri erano falsi, fuori di natura, e sagrificati al ridicolo grossolano, senza condotta, senza verità e senza ragione. Io moriva di voglia di metter mano ai caratteri veri, e di tentar la riforma ch'io divisava; ma non era ancora venuto il tempo, e ho dovuto contentarmi di lavorare passabilmente negl'Intermezzi(...) ${ }^{37}$

36 The tragedy went through the roof. It was liked for its suspense, its truth, and its pacing. I made the Emperor and the Captain speak as men speak, and not in the language of fantastical heroes, to which we are accustomed from the sublime pens of the most valorous Poets. When I wanted to express an emotion, I never sought the most recondite, the most elegant, or sublime term; but rather the most real, and the most expressive. I have seen from experience that simplicity never fails to please. By simplicity, I don't mean that I would make an Emperor speak in the manner of a shepherd; I mean to not have Sovereigns, who are men like us, speak in a language unknown to Nature.

37 ibid.; tomo XIII. In theatres in those days there were certain Comedies, solcalled di carattere, such as Count Pasticcio, Don Chisciotte, The Schoolteacher, The Forgetful, The Little Lord, The Tyrant, The Silly Servant, and others in good number; but the characters were fake, divorced from nature, and sacrificed to coarse humor, without action, without truth, and without reason. I was dying to try my hand at 
These words imply that, even while he was writing his first libretti, Goldoni's dramatist vein was leading him towards new ideals and a new philosophy of theatre. What is more, Goldoni's account testifies a conscious connection between his ideas for comedy and his texts for music; he works on one thing as he thinks of the other. It may be objected that Goldoni casts his intermezzi as a less appealing alternative to his works of greatest fame, from which one could suppose that he dedicated them less attention. Yet, we must remember that his reflections are written retrospectively, as an established playwright who has led a prolific career. In this light, it is certainly understandable that Goldoni (as he does elsewhere in his autobiographical writings) would wish to minimize his early musical production in favor of his more groundbreaking 'reformed' comedies.

We may further imagine that, if from the position of prestige and maturity from which he is writing his recollections the first intermezzi appear in retrospect to be of little consequence, when Goldoni was first given the opportunity to compose these texts, they were to him anything but marginal. As a young rebellious law student with great desire but no guarantee of a future career in theatre, the same intermezzi constituted his debut in a new field, and their quality and reception therefore were hardly inconsequential. Ultimately, Goldoni himself eliminates any doubt:

Egli è vero che avrei poi volentieri composte delle commedie di carattere ma pensai che, quantunque gli intermezzi non sieno che commedie abbozzate, sono però suscettibili di tutti i caratteri più comici e più originali, e che ciò potea servirmi di prova e di esercizio, per trattarli un giorno più distesamente $\mathrm{e}$ più a fondo nelle grandi commedie. ${ }^{38}$

real characters, and to attempt the reform I was envisaging, but the time had not yet come, and I had to content myself by working passably at my Intermezzi.

38 ibid., tomo XII. It is true that I would have later gladly written 'character comedies,' but I thought that, even though the intermezzi are but sketched comedies, they were nonetheless susceptible to all the most comic and most original characters, and this could serve me as practice and as exercise to develop them more extensively and deeply someday in the great comedies. 
The likening of intermezzi to 'sketched' comedies, capable of supporting original characters, makes clear that Goldoni did not divorce his work in the musical sphere from his instincts for comic prose theatre. It follows logically that what is only a nascent intuition in the intermezzi will take fuller form in Goldoni's drammi giocosi, written alongside his most mature theatrical comedies.

Goldoni's remarks are a consequence of the fact that, even with the success of Il Belisario, Imer preferred not to commission other tragedies from him, and instead requested texts for music. In fact, the company seemed to specialize in comic intermezzi, following the particular inclinations of their 'despotic' director:

La passione dunque che aveva l'Imer per gl'Intermezzi, ne' quali unicamente brillava, la fece [la Compagnia] perorare in favore di cotal genere di componimenti, e le prove che di me aveva vedute ne' due Intermezzi accennati [La Cantatrice and $\mathrm{Il}$ Gondoliere Veneziano], l'indussero a pregarmi a volerne per lui comporre degli altri, esibendomi con buona grazia, ed assicurandomi che mi avrebbe fatto ringraziare e ricompensare dal Cavalier suo Padrone, l'Eccellentissimo Signor Michele Grimani. ${ }^{39}$

The first intermezzi written expressly for Imer were therefore La pupilla (The Pupil) and La birba (The Trickster), both 1735 and set to music in "stile facile e chiaro" ('simple and clear style,' i.e. a low level of vocal difficulty for non-professional singers) by Giacomo Maccari, whose scores have been lost. La pupilla was an immediate success and secured Goldoni's standing as a theatrical author:

“...fu ben ricevuta e applaudita; e scorgendovi il Pubblico uno stile nuovo, cercarono di sapere chi ne era l'Autore, e sapendo che la medesima mano aveva composto La pupilla ed il Belisario, fu allora che cominciai a vedermi onorato di partigiani, di protettori ed amici." ${ }^{40}$

39 ibid., tomo XIII. The passion that Imer had for the Intermezzi, in which he shined like no other, made the Company an advocate in favor of this type of composition, and the proofs he had seen from me in the two Intermezzi I mentioned, induced him to request that I compose some others, showcasing me in good graces, and assuring me that he would have me thanked and rewarded by the Cavalier his lord, his Excellency Signor Michele Grimani.

40 ibid. It was well received and applauded; and the Public, seeing in it a new style, sought to discover its Author, and discovering that the same hand had written $\mathrm{La}$ 
The protagonists of this first success were Giovanna Farussi Casanova, mother of the famous Giacomo, and Imer himself, who played the role of her wooer on the stage and off. Through his Italian memoirs, Goldoni has informed generations of readers that Zanetta did not sing well. She was able to compensate for her musical shortcomings by means of her beauty and manners, which did not escape Goldoni's pungent creative eye: "(...) aveva io composto La pupilla per lei e aveva colto assai bene nella sua abilità principale, ch'era di una scaltra malizia coperta da una studiata modestia." 41 The practice of modeling his characters after real acquaintances is the secret to the veracity of Goldoni's original characters. This is a practice he would cultivate throughout his career, not always to the joy of those who recognized themselves all too well in his comedies.

If La pupilla found realism in its two protagonists, La birba was no less effective. "Birbi," as Goldoni explains, were those people who dealt with money in less than limpid ways, who sang and danced and begged for coins in Piazza San Marco, and who sing in his intermezzo in simple verse in evocation of street music of popular level. Again, Goldoni drew the efficacy of his text from the observation of daily scenes:

Trattenendomi di quando in quando nella Piazza San Marco, in quella parte che dicesi la Piazzetta, e veggendo ed attentamente osservando quella prodigiosa quantità di vagabondi, che cantando, suonando o elemosinando, vivono del soave mestier della birba, mi venne in mente di trar da coloro il soggetto di un Intermezzo giocoso; e mi riuscì a maraviglia. ${ }^{42}$

The result was that La birba surpassed La pupilla in its success, confirming Goldoni's career as a librettist. At this point, Goldoni's name began to grow in public notoriety, as did his own consciousness of his

pupilla and Il Belisario, it was then that I began to see myself honored by supporters, protectors, and friends.

41 ibid. I had written La Pupilla for her, and I had hit the target very well in her greatest ability, an astute malice covered by studied modesty.

42 ibid. Lingering from time to time in Piazza San Marco, in that part called the Piazzetta, and seeing and attentively observing that prodigious quantity of vagabonds, who singing, playing, and begging, live by the sublime trade of the 'birba,' I had the idea of drawing from them the subject of an Intermezzo, and I succeeded marvelously. 
vocation, and at times, as the author himself admits, his 'hot head.' In the same year as the two intermezzi with Imer, Goldoni was also asked to arrange a libretto for Antonio Vivaldi. Even if not directly related to his comic production, this episode is worth recalling not only for the memorable image of our author vexed and provoked by the 'red priest,' but also because it serves perfectly to give a sense of who Goldoni was as a man, his own comic personality just as original as that of his staged characters.

Here then is a page from the Prefazioni ai Diciassette Tomi delle Commedie edite a Venezia da G.B. Pasquali of 1761 (Prefaces to the Seventeen Volumes of Comedies published in Venice by G.B. Pasquali), later published as Memorie Italiane:

Era il compositor della musica di quell'anno per l'Opera dell'Ascensione il Signor Abbate Vivaldi, detto il Prete Rosso, per il colore de' suoi capegli, e malamente da alcuni chiamato il Rossi, credendolo il nome della sua famiglia.

Questo famosissimo suonator di violino, quest'uomo celebre per le sue Suonate, specialmente per quelle intitolate le Quattro Stagioni, componeva altresì delle Opere in musica; e quantunque dicessero i buoni conoscitori ch'egli mancava nel contrappunto, e che non metteva i bassi a dovere, faceva cantar bene le parti, e il più delle volte le Opere sue hanno avuto fortuna....

Premeva estremamente al Vivaldi un Poeta per accomodare o impasticciare il Dramma a suo gusto...ed io, che ero destinato a tale incombenza, mi presentai al compositore... Mi ricevette assai freddamente. Mi prese per un novizio, e non s'ingannò, e non trovandomi bene al fatto nella scienza degli stroppiatori de' Drammi, si vedea ch'egli avea gran voglia di rimandarmi.

Goldoni's first task is to adjust an aria, and, vexed and stricken in his honor for being treated as a 'novice' by a composer of 'scarce' counterpoint, he demands pen and paper and a chair and begins to write there in the room with Vivaldi. In little time, the deed is done:

Gliela porto, gliela faccio vedere, tiene colla dritta il breviario, colla sinistra il mio foglio, legge piano; e finito di leggere, getta il breviario in un canto, si leva mi abbraccia, corre alla porta, chiama la Signorina Annina [la protagonista cantante]. Viene la Signorina Annina, e la Signora Paolina sorella: legge loro l'arietta, gridando forte "l'ha fatta qui, qui l'ha fatta, l'ha fatta qui"; e nuovamente mi abbraccia, e mi dice bravo, e sono diventato il suo caro, il suo poeta, il 
suo confidente, e non mi ha più abbandonato. Ho poi assassinato il Dramma del Zeno quanto e come ha voluto. ${ }^{43}$

Remarkable, stylistically speaking, is the way Goldoni uses the present tense to narrate events in detailed sequence. His description of every gesture allows the reader to visualize the scene as if it were performed on a stage. Indeed, the most memorable episodes of Goldoni's autobiography are always narrated in a theatrical style of prose.

In the year following his first works for Imer and Griselda, Goldoni continued to develop the intermezzo with L'ipocondriaco (The Hypochondriac) and Il filosofo (The Philosopher) in 1735, followed by Monsieur Petiton, La bottega da caffè, and L'amante cabala (The Lying Lover) the next year. The original music for these works has not survived, but from the texts we can spot arias in vivacious polymeter, and recitative in a mix of Venetian dialect and Italian, along with a few foreign languages in parody. Most importantly, Goldoni continues to form his characters in the likeness of real-life acquaintances. Stiffoni has attributed the success of these works precisely to their distinct characterizations, that is to a type of "gioco scenico, appoggiato non solo

43 ibid. The composer of music in that year for the Opera of the Ascension was the Abbot Antonio Vivaldi, called the Red Priest for the color of his hair, and erroneously by some called Rossi, believing that to be his family name. This very famous violinist, this man so famous for his Sonate, especially those titled The Four Seasons, also composed musical Operas; and though the connoisseurs were saying that he was lacking in counterpoint, and that he didn't place his bass lines as he should, he made his parts sing well, and more often than not his Operas met with good success (...) It was very pressing for Vivaldi to find a Poet to accommodate or mess up the Dramma to his liking... and I, the intended for this chore, introduced myself to the composer... He received me quite coldly. He took me for a novice, and he was not wrong, and finding that I was not experienced in the art of mangling Drammi, it was evident he had great desire to send me away.

(...) I bring it to him, I let him see it, he holds a prayer book in his right hand, in his left my sheet of paper, he reads slowly; and, finished reading, tosses his prayer book away, springs up and hugs me, runs to the door, calls Mlle. Annina. Here comes Mlle. Annina, and Mme. Paolina her sister: he reads them the arietta, yelling loudly "he wrote it here, here he wrote it, he wrote it here;" and once again he embraces me, he says bravo, and I have become his dearest, his poet, his confidant, and he never left me after that. I then assassinated Zeno's dramma as much and however he wished. 
alla battuta comica ma anche sulla definizione dei singoli personaggi, nella maggior parte dei casi disegnati in maniera assai efficace." 44

This we see, for example, in L'ipocondriaco and Il filosofo, which delve more deeply into the psychological musings of their protagonists, as Goldoni will continue to do in the 1740 s with his first complete comedies. The counterpart female roles remain less developed, and the action is still quite simple in its structure. In terms of content, both works are satirical, and as such offer light-hearted but scathing commentary on their respective subjects, L'ipocondriaco a parody of false medicine, and $I l$ filosofo a parody of scholasticism and false literature. It is likely that both were loosely drawn from very early pre-existing intermezzi, Erighetta e don Chilone (1707), and Pollastrella e Parpagnacco (1708), respectively.

The three intermezzi of 1736 are especially significant on the path to comic opera, because they begin to display not only original content but also structural elements that will characterize the later dramma giocoso. Monsieur Petiton, whose protagonist is a narcissistic 'dandy,' is novel in its employment of four principal actors, brought together at the end of each act in what would later be canonized as the ensemble finale. In La bottega da caffè and L'amante cabala, Stiffoni sees the "stato embrionale del dramma giocoso." ${ }^{45}$ These works are expanded from the original two acts and are articulated in three. La bottega da caffe is decidedly more complex in its design than previous intermezzi. Narciso, owner of the coffee shop, intends to marry Dorilla, his beloved. To better bring this about, both employ art and subterfuge to strip wealth from the older, gullible Zanetto. This tale is as old as time, and will reappear in Goldoni's first dramma giocoso, La scuola moderna (1748), in which the protagonist, coincidentally, is named Drusilla. According to their strategy, Dorilla flirts with Zanetto compelling him to give her gifts, and Narciso interrupts each scene at just the right moment so that she does not have the chance to refuse or return them, as honesty would dictate. This type of plot, in which the element of surprise is key, affords

44 Gian Giacomo Stiffoni, "Introduzione" in Carlo Goldoni, Intermezzi e farsette per musica, a cura di Anna Vencato (Venezia: Marsilio, 2008); 20. Stage play, supported not only by the witty line but also by the definition of each single character, in most cases portrayed with great efficacy.

45 The embryonic state of the dramma giocoso, ibid., 26. 
rapid exchanges in dialogue, another element Goldoni will preserve in the drammi giocosi. The real novelty of this intermezzo however is the opening of the third act, which does not begin with recitativo but immediately with an ensemble, Dorilla and Narciso sharing the aria, "Cara man che me consola."

L'amante cabala begins similarly with a duet between principal characters Lilla and Filiberto. Filiberto is the "cabalon," or spinner of lies, who tries to court both Lilla and Catina at the same time, telling each that the other has lost her wits. Filiberto has much in common with the Don Giovanni figure, whom Goldoni certainly had fresh in his mind, for in the same year (1736) he also authored his own Don Giovanni Tenorio, a comedy in verse that contains interesting departures from the original by Tirso de Molina. At the end of the intermezzo the transgressor is defeated, and the moral of the story is announced directly to the public, "Imparino tutti,/ da sì bell'esempio/ che l'arte d'un empio/ trionfar non può." ${ }^{46}$ Goldoni will often close his drammi giocosi in this sententious manner, a practice Mozart and Da Ponte will continue in their masterworks. Also worthy of note is the character Lilla, who speaks in a more elevated register than the others, almost in reminiscence of opera seria (Stiffoni identifies Metastasian influence in her part). Her role within the work marks the beginning of a differentiation of tone and role between characters, and the first shades of pathos in a comic plot.

While Goldoni establishes himself as a promising librettist under Imer, he is also invited, from 1735, to create musical comedies for another Venetian theatre, the San Samuele, also owned by the Grimani family. These works are of sundry nature, but nonetheless merit mention as they constitute a link between Goldoni's intermezzi, suspended after 1736, and a different and more complete kind of musical theatre, the dramma comico, which in retrospect appears the final step before the dramma giocoso. The texts written for the Teatro S. Samuele testify the absence of a unifying comic opera tradition: Aristide (1735) is a dramma eroia comico, La Fondazion de Venezia (The Founding of Venice, 1736) a divertimento per musica, Lugrezia romana in Costantinopoli (Lucretia of Roma in Constantinople, 1737) a dramma per musica, and finally, La Contessina

46 Carlo Goldoni, L'Amante Cabala, scena ultima. May all draw a lesson from such an example, the art of a villain can never succeed. 
(The Little Countess, 1743), commedia per musica. The musical scores that first accompanied these works have been lost, but were likely composed by the roman Giacomo Maccari. Anna Vencato has suggested that the scarce homogeneity of these works is also a product of the author's efforts to provide the best comic fit for the varied company of actors of the S. Samuele. ${ }^{47}$

While Lugrezia Romana is an exemplary parody of opera seria, other works among those listed above reveal new elements that will remain in the dramma giocoso. The Prologo to La Fondazion di Venezia, for example, is an allegorical dialogue between Musica and Commedia that reveals Goldoni's philosophy of comic theatre, and heralds the presence of serio elements in comic opera. Personified Music, who hearkens from the timeless depths of archaic opera, represents the noble sphere of tragic theatre, while Comedy draws her merits not only from her ancient past but especially from her present glory in the city of the lagoon (“Quanto l'itala scena/ Di me si pregi,/e quanto in questi lidi"48). The higher power of Comedy appears to draw from the Horatian metaphor of utile and dilettevole united in art; as a remedy against vice, she provides sweet laughter to soften the bitter medicine of self-realization:

La Commedia son io: Quella che su le scene Dà lode alla virtù, biasmo agli errori, Mostrando in varie guise "Le donne, i cavalier, l'arme e gli amori;" Quella per cui sovente Di sé mirando il vergognoso esempio, Detesta il vizio, e divien giusto un empio. A chi crede un vago volto Posseder senza difetto, Quel cristallo parla schietto, E gli dice: «Mira, o stolto, Quanti errori ha tua beltà. Così appunto a chi non crede Reo di colpe il suo costume, Io presento un chiaro lume Onde poi se stesso vede, e l'error scoprendo va. ${ }^{49}$

47 "Introduzione" in Carlo Goldoni, Dramma musicali per i comici del San Samuele, a cura di A. Vencato (Venezia: Marsilio, 2009); 3.

48 Carlo Goldoni, La Fondazion di Venezia, Prologo. How much the Italian stage/ is honored by me/ and how these very shores.

49 ibid. I am Comedy/she who on the stage/gives praise to virtue, and reprimands the errors/showing in different guises/"Le donne, i cavalier, l'arme e gli amori" [Note also the citation from Ariosto]/she by whom often/seeing of oneself the shameful example/the villain detests his vice, and becomes righteous. To who believes to have a countenance/ beautiful and without flaw/ that mirror does speak plainly/ saying: 'Look, fool/ See how many flaws your beauty holds'/ In the same way, to 
The chosen metaphor of Comedy as a mirror implies a reflection of the individual made possible only through realism and honest social characterization. In these few verses, we find the essence of two of Goldoni's core convictions: first, that comedy must reflect the realities of society and its members, and second, that it has the ability to fulfill a higher calling of social commentary and moral instruction.

Where Comedy is direct, Music's verses are allusive. Her greatest power is described in these terms: "Io sol posso tener gli animi intenti/ Al dolce suon de' miei canori accenti, ${ }^{50}$ a clear echo of the Platonic belief in Music's power to move the affections, and a logical connection of this art to the ennobled, contemplative virtues of tragic opera. She underlines her connection to tragedy by evoking Metastasian theatre, "Ora per la virtù risorto è il zelo,/ Ed io sono virtù che vien dal cielo," the new 'zeal for virtue' a clear reference to the Arcadian reform. In sum, Music and Comedy personified represent not only two different artistic spheres, but more subtly the interplay of comedy and tragedy (represented by Music's ancient origins) within a single work. The challenge is striking the most natural equilibrium between these two elements. As both arts assert their primacy and their dispute degenerates into increasingly violent tones, order is restored by the mystical Genio dell'Adria (who we may understand to be a local demi-god or genie, guardian of the Adriatic sea), who delivers the final sentence:

Olà donne fermate Qual ira vi trasporta? Qual inganno vi spinge a gara ostile? Non vi recate a vile Vivere in buona union, se pur può darsi, 'Ve la Commedia giace, Che Concordia si trovi, e regni pace. Oggi l'una di voi non è bastante Senza l'altra piacer su queste scene. Se non ha la Commedia L'ornamento del canto, Spera invan riportar applauso e vanto; E la Musica stessa, Se non ha ne' suoi drammi oltre ragione Qualche comica azione, Se conserva il rigor della Tragedia, Anzi che dar piacer, suo canto attedia. Eugualmente ad entrambe La stessa sorte arride: Cosi il Genio dell'Adria oggi decide. ${ }^{51}$

who does not believe/ their conduct to be at fault/ I bring a bright light/so then he sees himself/ and discovers his mistake.

50 ibid. I alone have the power to keep souls attentive/ With the sweet sound of my song (...) Now the zeal for virtue has risen again/ And I am that virtue that comes from the heavens.

51 ibid, Hold, women, cease./What fury moves you?/ What treachery spurs you to such hostile contest?/Do not disdain/ to live in happy union, if that is possible/ 
In sum, on the modern stage one art can no longer succeed without the other; song cannot live without words, comedy and tragedy cannot succeed without some aspects of the other. As Anna Vencato has noted, Goldoni's mediated resolution is strongly reminiscent of an earlier Venetian text published for the actors of the same theatre: Introduzione alle recite della truppa dei comici nel teatro Grimani a S. Samuele, per l'Autunno di quest'anno 1726, posta in musica dal Sig. Gio. Battista Pescetti (Introduction to the Performances of the Actors' Troupe of the Grimani Theatre in S. Samuele, for the Fall of this year 1726, set to music by G. B. Pescetti) is its full title on the frontispiece. Here too a lofty prologue precedes the actors' entrance, an exchange between the familiar Adria, in this case a goddess, and Neptune. The curtain rises to give a view of the sea, populated with playful water creatures, in the midst of whom we find "Adria sopra d'una Conchiglia tirata da due Mostri Marini, poi Nettuno sopra d'un altra." 52 Adria pronounces these words, clear presage of a new preference:

Ma già che l'ora è presso,

In cui debbon gl'Attori

Far di se stessi una pomposa mostra,

E del loro valor darne l'assaggio;

Vanne, tutti gl'invia In questa spiaggia, e dille,

Ch'io vo veder in questa prima impresa

Misto al serio il giocoso,

Il ridicolo al grave, e ogn'un s'adopri

Che dall'alto mio Soglio,

Il merito d'ogn'un pesar io voglio..$^{53}$

that where Comedy lies/ we find concord, and that peace reign./ Today, each one of you is not enough/ pleasure without the other on the stage./If Comedy does not have/ the ornament of song,/ she may hope in vain to win applause and fame/And Music herself/ if in her drammi, along with reason/she does not hold some comic action/if she preserves the rigor of Tragedy,/ instead of giving pleasure, her song will bore./ Equally on both/ the same fate smiles/ this I rule today.

52 Introduzione alle recite della truppa dei comici nel teatro Grimani a'S. Samuele, per l'Autunno di quest'anno 1726, posta in musica dal Sig. Gio. Battista Pescetti (Venezia: Valvasense editore, 1726); 3. Adria atop a seashell drawn by two sea monsters, then Neptune atop another.

53 ibid; 5. But since the hour is near, in which the actors must/ make of themselves a magnificent show/ and give us proof of their worth;/ Go, and send them all/ to 
The auspice of a coexistence of serio and giocoso, ridicolo and grave, recaptured in Goldoni's divertimento, foreshadows a change in the aesthetic of theatre, fertile ground for Goldoni's first experimentation and for the dramma giocoso.

\section{ii. New directions for comedy}

While opening his texts to new dramatic possibilities in the field of music, Goldoni was also making strides as a comic playwright. Just as he ameliorated the intermezzi into more realistic, and self-sufficient works, he likewise soon felt constrained by the fixed practices of the Commedia dell'Arte and compelled to expand and diversify his cano$v a c c i$. The criteria that animated his innovations, the essence of his later "reform," was the same desire for realism, originality, and novelty that he could more freely pursue in his texts for music.

Before we approach Goldoni's innovations in prose comedy and their rapport with his musical output, it is essential to first understand the true nature of the Commedia dell'Arte from which these stem, as this tradition is often misrepresented and misunderstood. The origins of the Commedia dell'Arte are quite ancient. Some scholars identify a first manifestation in the works of the Paduan Angelo Beolco, known as Ruzante ( 1502? 1 1542?), though it was also cultivated in the south of Italy. Ruzante's comedies were among those performed at the first Venetian public theatres in the Seicento. Some of these, written in Paduan and Venetian dialect, use recurring figures and farcical action that for some scholars appear to foreshadow the Commedia masks and character types. His comedy L'Anconitana (The Girl from Ancona, 1530), for example, in which Ruzante himself performed the role of a humble farmer, features a duet between servant (Ruzante) and master (Sior

this shore, and tell them/that I wish to see in this first work/the comic mixed with tragic/ the ridiculous mixed with the weighty, and that everyone make an effort/ for, from my high throne/ I wish to weigh the merit of each. 
Tomà) in which we may see prototypes of the boisterous Arlecchino and his master Pantalone, old, wise, and frugal.

Ruzante as creator and performer exemplifies the diffused custom among early modern authors to double as actors in their works. The practice is largely lost today, but it was habitual for Shakespeare, Molière, and others. In this respect, Goldoni appears one of the first letterati amidst other icons of theatre who had direct experience in recitation. The common source of authorship and acting is particularly critical to the Commedia dell'Arte, which draws its name from arte as "artisanal," a trade of skill. While often dismissed as theatre of 'stock comedy,' the Commedia in origin was fruit of the ingenuity of men of great culture and skill who not only performed but created their roles. Its allowance for improvisation, later to become a hindrance to the development of plot, in origin blossomed entirely from the wit and captivating personality of its first actors, who just as Ruzante were men of letters and authors in their own right. The first generations of Commedia actors were respectable and prominent figures, such as Antonio Sacchi (1708-1788), born one year after Goldoni in Vienna to a Neapolitan family of comic actors. ${ }^{54}$ A true uomo di mondo, Sacchi ventured far and wide through Europe and Russia, and died at sea. He was one of Goldoni's principal actors but also performed for Carlo Gozzi and Pietro Chiari, Goldoni's fiercest competitors. Accounts testify that Sacchi was a man of great wit who specialized in the mask of Arlecchino (or Truffaldino), no doubt excelling in the lazzi (episodes of free improvisation, both linguistic and physical) so typical of that mask. That Sacchi was a man of high culture is testified by his correspondence with diplomats and ambassadors, and Giacomo Casanova refers to him as a model of political eloquence. The original Commedia dell'Arte, therefore, was clearly the opposite of the repetitive, unoriginal, and economic trade it is often interpreted as from a post 18th century perspective.

From the newly uncovered papers of Carlo Gozzi, it has emerged that Sacchi, an admirer of Caldéron de la Barca, also liked to recite without a mask and in verse. Goldoni, like Sacchi, gradually steered

54 More information on this topic has been provided by the work of Siro Ferrone and Ferdinando Taviani, among others. 
away from the masks of the Commedia dell'Arte, beginning with his comedy Momolo cortesan (1738). For scholarship, this comedy marks the beginning of his "reform," a veritable hybrid between Commedia and new, non-improvised comedy. Momolo, the protagonist, for the first time in the history of comic theatre, recites from a part entirely written out from beginning to end, while the actors around him continue to improvise in the traditional manner. The success of this work was such that it prompted two sequels (likewise made up of written and improvised parts), Il Momolo sulla Brenta (Momolo on the River Brenta, 1739), and Momolo mercante fallito (Momolo the Bankrupt Merchant, 1740). The three works would later be purged of their masked characters and published under the new titles L'uomo di mondo (The Man of the World), Il prodigo (The Prodigal), and La bancarotta (Bankruptcy). ${ }^{55}$ From their new titles alone it is easy to infer that not unlike Goldoni's other musical or spoken theatre, these works contain a healthy dose of social critique, targeting in this case the figure of the profligate.

The same is true of La contessina (1743), no longer an intermezzo but a commedia per musica that represents a delicate point of transition from Goldoni's early musical texts to the definitive confirmation of his philosophy of theatre and his output as an established librettist. Regarding early intermezzi, Paolo Gallarati rightly observes "L'atteggiamento caricaturale degli intermezzi impediva al pubblico l'immedesimazione nei personaggi ed una eventuale partecipazione affettiva ed emotiva alle loro vicende," ${ }^{56}$ a notion clearly confronted, resolved, and definitively surpassed by Goldoni with La contessina. The social critique embedded in this work (in essence the incompatibility of the aristocratic class structure with new rationalistic, Enlightened perspectives on the

55 It is very important to recognize that revisions for publications were, in Goldoni's first stage, largely responsible for the apparent 'disappearance' of the Commedia dell'Arte masks. In reality, despite a few exceptions as for example La Pamela, most of Goldoni's 'new' comedies given at the $S$. Angelo were still largely improvised- a practice dictated by necessity more than by tradition, given the extremely limited time available for rehearsals before each new premiere. The parts acquired a definitive, fixed setting when they went into press, but realistically not before.

56 Paolo Gallarati, Musica e Maschera, (Torino, EDT, 1984); 100. The caricatural approach of the intermezzi prevented the public from empathizing with characters and experiencing emotional involvement in their affairs. 
individual) is more direct and audacious than ever before, and is made possible by the realistic portrayal of a diversified class structure. Linguistic differences accentuate deeper differences in social philosophy, and unequivocally anchor this work in its own time, reason perhaps for its success.

The few years following saw Goldoni leave Venice for a time due to financial difficulties. He consequently also left his 'official' job of consul of the Republic of Genoa in Venice (held since 1740), and suspended the creation of new libretti. The next years saw him in Bologna, Modena, Rimini, Firenze, Siena, and finally Pisa, where he remained until 1748 and obtained inclusion in the Accademia degli Arcadi, taking the pseudonym Polisseno Fegejo that is occasionally appended to his later libretti. During these years, Goldoni continued to practice law and write for the theatre, mainly scenari (canovacci) but also his first comedy, La donna di garbo (The Well-Mannered Lady, dated 1743 but premiered some years later).

It was during these travels, and in particular thanks to a famous Pantalone, Cesare Arbes (1710-1778), that Goldoni was introduced to Girolamo Medebach, whose wife Teodora would play the first donna di garbo. Medebach was capocomico of the Teatro S. Angelo in Venice, and in 1748 offered Goldoni a four-year contract for eight new comedies and two new operas each season. Though Goldoni would not renew his contract after 1752 because of fierce copyright disputes, Medebach would still prove to be perhaps the single most important figure in his career. In particular, it was during Goldoni's span of collaboration with Medebach that he was able to write and produce the most important comedies that would launch his "reform."

The Teatro $S$. Angelo was a unique venue, the only theatre in Venice not owned by an aristocratic family, therefore Medebach, who was renting it for his company after Carlo Gozzi (Goldoni's future rival) had moved out, was able to keep his troupe's playbills open to Goldoni's new ideas. In this small theatre, our author found fertile ground for experimentation that elsewhere would not have been accepted. Naturally, Goldoni continued to tailor the characters of his works to the personalities of his actors, and opened the 1748 season with La vedova scaltra (The Shrewd Widow), created for Teodora Medebach (for whom 
Goldoni's Memorie Italiane betray a certain fondness), followed by a great number of original- and innovative- comedies.

Goldoni's demanding collaboration with Medebach did not however keep him from writing for other theatres at the same time, most notably the Teatro Giustinian. This small theatre, better known as the Teatro San Moisè because of its vicinity to that church, was inaugurated in 1640 with Monteverdi's Arianna, and would go on become one of the city's leading opera houses (though it housed comedy as well), closing with Rossini's operas in the early 19th century. In the latter 1740 's, it gave home to Goldoni's first developing musical comedies under the auspices of impresario Angelo Mingotti. For production at the Teatro San Moisè between 1748-49, Goldoni wrote La scuola moderna, Bertoldo, Bertoldino e Cacasenno, and La favola dei tre gobbi (The Fable of the Three Hunchbacks), all set to music by Vincenzo Ciampi (17191762). This season marks a point of arrival for Goldoni, for La scuola moderna is his first dramma giocoso, and Goldoni, now an author who has tested and proven his intuitions, is ever more determined to pursue new, realistic, and socially relevant theatre.

\section{iii. A new art for a new society: the dramma giocoso takes shape in Venice}

The earliest known drammi giocosi ever performed in Venice were given in 1744: La libertà nociva (The perils of freedom) and L'ambizion delusa (Disappointed ambitions), both composed by Rinaldo di Capua on texts written or readapted by Giovanni Barlocci. They were given at the S. Cassiano theatre, which, taking example from the already successful S. Samuele and S. Moisè, was giving more and more space to comic opera, given its growing popularity. These are, however, sporadic titles among a myriad of other genres in circulation, including opere bernesche, commedie per musica, divertimenti, farsette among others. Then again Goldoni too tried his hand at opera seria, intermezzi, drammi eroi-comici, divertimenti, and others still without ascribing to any one genre in particular- until his first dramma giocoso, La scuola 
moderna of 1748. After 1748, Goldoni will instead write almost exclusively drammi giocosi, and these will gain notoriety internationally.

Bearing a sarcastic alternate title of La maestra di buon gusto (The Teacher of Good Taste), Goldoni's scuola moderna (The Modern School) displays all of the characteristics of the genre in embryonic state. It was set to music by Gioacchino Cocchi (1712-1796), soon thereafter to become director of music at the Venetian Ospedale degli Incurabili, but his score has been lost. In reality it is not wholly original but a pasticcio: the author inserted new comic material around preexisting text- a practice then quite common but which Goldoni would never replicate. Antonio Groppo, a contemporary of Goldoni who kept catalog of the works performed in various Venetian theatres, identifies La semplice spiritosa (The Witty Naïve Girl) as the source, while recent studies suggest in addition a Neapolitan opera, La maestra (1747), by A. Palomba. ${ }^{57}$ In any event, the real discovery in this work is what Goldoni himself writes in the preface:

Non avendo servito il tempo per mutar tutta l'opera, come erasi divisato, si è mutata tutta la materia buffa, la quale, se non parerà bene intrecciata colla seria, ciò è provenuto per la necessaria brevità; e vivi felice. ${ }^{58}$

The dramma giocoso, as a genre, is precisely defined as 'comic material...interwoven with tragic.' And notwithstanding the fact that this first, however rushed, attempt draws its 'tragic' parts from an existing text, all of Goldoni's subsequent- and entirely orginal- libretti confirm the novelty: comedy and tragedy in a new coexistence within the same work, even if- at this early stage- in parallel plot lines.

The possibilities granted by this combination will make the dramma giocoso, and later on opera buffa, one of the most popular products of $18^{\text {th }}$ century musical culture, and a pillar of our opera tradition to this

57 See Anna Laura Bellina, "La 'Maestra' esaminata," introduction to G. Cocchi, $L a$ maestra, (Milano: Ricordi, 1987); and Eleanor Selfridge1 Field, A New Chronology of Venetian opera and related genres, Standford University Press, 2007; 514.

58 Carlo Goldoni, La Scuola Moderna, Forward. Not having had the time to rewrite the whole work, as was originally devised, all of the buffo material has been modified, which, if it should not appear well1 connected to the serio, this is the result of necessary brevity; and may you live happily [so be it]. 
day. But what exactly can the coexistence of buffo and serio bring to musical comedy? Perhaps some of that same realism that was the harbinger of modern theatre. When Goldoni writes his Il Teatro Comico (The Comic Theatre, 1751), the comedy that, retrospectively, formalizes his ideals for a renewed, socially relevant theatre, his characters convey a very important point on his behalf:

PLACIDA. Perché dunque vogliamo fare una farsa, e non più tosto una delle migliori commedie?

ORAZIO. Cara signora, sapete pure, che ci mancano due parti serie, un uomo, ed una donna. Questi si aspettano, e se non giungono, non si potranno fare commedie di carattere.

PLACIDA. Se facciamo le Commedie dell'Arte, vogliamo star bene. Il mondo si è annoiato di veder sempre le cose istesse, di sentir sempre le parole medesime, e gli uditori sanno cosa deve dir l'Arlecchino, prima ch'egli apra la bocca. Per me, vi protesto signor Orazio, che in pochissime commedie antiche reciterò; sono invaghita del nuovo stile, e questo sol mi piace...etc. ${ }^{59}$

These brief exchanges lay out a fundamental principle of goldonian realism: parti serie are essential to modern comedy too, not just to modern musical theatre. And who better to voice these convictions but Placida, stage-name of Teodora Medebach (wife of the impresario who employed Goldoni, who left quite an impression in the playwright's life), who, as Ginette Herry wrote, “(...) non ha eguali nelle parti patetiche con le quali, come nessun'altra, riesce a rendere umidi gli occhi degli spettatori (...) diventa quindi la colonna della riforma"60; an actress, in other words, who excelled in parti serie and sentimentalism. Naturally, in the libretti the tragic elements, initially at least, owe their existence as much to the standing tradition of opera seria as they do to Goldoni, just as it is true that serio characters (or amorosi) where not extraneous to the Commedia dell'Arte either. Yet the juxtaposition of comic and tragic is a dichotomy that Goldoni's texts for music will gradually attenuate,

59 Carlo Goldoni, Il Teatro Comico; I, ii.

60 Ginette Herry, "Carlo Goldoni e la Marliani ossia l'impossibile romanzo" in Studi Goldoniani quaderno 8, (Venezia: Casa di Goldoni e Istituto di Studi Teatrali dei Musei Civici Veneziani, 1988); 141 ...had no equals in playing sentimental roles, with which, like no other, she could wet the eyes of her listeners...she became therefore a pillar of the reform. 
and eventually eclipse. The end result yields no resemblance to the serio styles of tragic opera, ushering in a modern, calibrated, psychologically intimate approach to characters and plot; a synthesis that is perhaps the greatest legacy of $18^{\text {th }}$ century musical theatre.

La scuola moderna does not- and logically cannot, being the first 'prototype'- display the seamless homogeneity of later works. The preface already makes net distinction between buffo and serio, a division carried out faithfully through characters and plot lines. This work does, however, carry all the elements essential to the evolved dramma giocoso, including Goldoni's compulsive pricks and prods at contemporary mores. We are, after all, in the 'modern school', and the cardinal rule of modernity appears to be self-interest.

Drusilla, the 'teacher of good taste', sings an opening aria that says it all:
Io li vedo a tutte l'ore
tutti ricci e incipriati,
far la ronda alle signore
far con esse i spasimati,
ma che cavino un quattrino
dall'afflitto borsellino
lo credete?
oh questo no.
Se vogliamo de' sospiri, gran promesse e gran parole, lor ne danno a chi ne vuole, ma regali non si può. ${ }^{61}$

Notwithstanding the flaws and materiality of her character, Drusilla alludes to themes that ring true. Through the image of gentlemen with perfected hair, powdered complexions, and empty promises, Goldoni returns to a deep-rooted issue confronted nearly ubiquitously in his theatre: appearance and reality ever more at odds. As the aristocracy begins

61 ibid., Act I, iii. I see them at all hours/ their hair curled and their skin powdered/ tailing 'round the ladies/ acting so in love,/ but do they ever take a dime/ out of their afflicted purse/ would you think? no, certainly not./ If we want sighs/ grand promises and lofty words/ these they give to whoever may desire them/ but gifts are not possible. 
to weaken financially, many go to great lengths to maintain a façade of grandeur and influence, though with little means to do so. There is, consequently, an exteriority, and vanity, that finds no real foundation in truth.

In a future ever more uncertain, the laws of self-interest appear the most pragmatic approach to security. At 'the modern school' - set in Venice, no less- the pupils, young men and women at the shores of marriage and independence, don't study grammar or geometry but rather how best to manipulate their parents, tutors, or guardians to their own advantage. By Goldoni's jesting account, modernity is apparently the era of falsehood:

Tutti fingono, tutti.

I mercadanti, per mantener i vizi e le gran spese,

fingon la roba di lontan paese;

gli orefici, vendendo la tombacca per oro,

guadagnano un tesoro.

Gli avvocati fingono che il cliente abbia ragione, sol per mangiargli il fegato e il polmone;

e i medici, fingendo la malattia mortale,

traggon il proprio ben dall'altrui male;

fingon gli uomini affetto, ed è interesse;

fingon le donne anch'esse:

vedrai un bel visin, ma quello è finto,

con la biacca e il carmin coperto e tinto. ${ }^{62}$

The scene is clearly comic, but in this sweeping panorama of corruption that brings to mind Goldoni's model, Molière, humor takes second place to truth.

In net contrast to the tone, pacing, and broader social commentary of Goldoni's comic roles, the serio material of this pasticcio, which the author chose to preserve from its original version, is a return to the realm of Metastasian opera, and without any hint of parody. Rosmira, a young noblewoman, is prevented from marrying Ergasto, whom

62 ibid., Act I, vii. Everyone pretends, everyone. Merchants/ to support their vices and large expenses/ pretend their goods come from distant lands/goldsmiths, selling copper for gold/ rake up a fortune. Lawyers/ pretend their clients are in the right/ only to strip them of liver and lungs/ and doctors, feigning/ the illness to be lethal/ draw their profit from others' misfortunes;/ men feign affection, but it is interest/ and women pretend too:/ you see a pretty face, but it's fake/ covered up and colored with flour and blush. 
she loves, because he is desired by her aunt. Rosmira, continually mistreated, and Ergasto, grieved by his own suffering and hers, sing in measured verse, stylistically miles away from the rapid exchanges, puns, and wit of the comic parts. Their language carries generic tragic leitmotifs, as for example Ergasto's first solo aria,

L'alma gelar mi sento sento mancarmi il cor oh che crudel momento! che sfortunato amor! etc. ${ }^{63}$

or his beloved's, accordingly:
Troppo è crudel tormento questo che in cor mi sento.
Un giorno intero senza veder l'amante, è pena da morir. ${ }^{64}$

This is the tone, quite stiff by our standards, held exclusively by characters of noble birth. Both examples are fragments of exit arias which, in the manner of opera seria, expound upon a single emotion or state of mind without advancing the plot.

While still underdeveloped at this stage, and a bit clumsy at that, the coexistence of buffo and serio clearly visible in this first dramma giocoso undeniably opens a much ampler spectrum of dramatic registers, and demonstrates high potential for greater intricacy through the structure of a double plot.

The final important feature of La scuola moderna, and part of the blueprint for future drammi giocosi, is Goldoni's manner of closing acts with ensembles, as in his intermezzi. This practice is by no means unique him- on the contrary its origins are quite ancient- but Goldoni will make an original and lasting contribution here too, by later adapting the

63 Carlo Goldoni, La Scuola Moderna, Act I, vi. I feel my soul freezing/ my heart giving way/ oh, what a cruel moment! /what ill-fated love!

64 ibid., Act I, x. Too cruel is the torture/ that I feel in my heart. An entire day/ without seeing my love/ is a deathly pain. 
so-called 'ensemble finale' to the ends of internal scenes, and eventually even within scenes as part of the action.

At this primary stage we see ensembles at the ends of acts only, but even within the well-worn custom Goldoni introduces new life by juxtaposing parallel conversations between couples (caught in the inevitable love-triangle). The conclusion of Act I, for example, is strongly reminiscent of the lively quickness of the Neapolitan commedia per musica:

BELFIORE. Cara, cara.

DRUSILLA. Caro, caro.

LINDORO (a Belfiore). Senta, senta, mio padrone.

BELFIORE (a Lindoro). Bernardone, bernardone.

BELFIORE (a Drusilla). Mia sarete?

DRUSILLA. Se vorrete.

LINDORO (a Belfiore). domandato è in verità.

BELFIORE. Va in malora, via di qua.

DRUSILLA. Zitto, zitto, taci là.

BELFIORE. Per te cara, io vivo in pene.

DRUSILLA. Io vi voglio tanto bene.

LINDORO. (verso la scena). Si signore, viene, viene.

BELFIORE. Con chi parli?

DRUSILLA. E' domandato.

LINDORO. (a Drusilla). Traditora!

DRUSILLA (a Lindoro). Sconsigliato!

BELFIORE. Bernardone, mi hai beffato.

LINDORO. No, davvero, ve lo giuro.

DRUSILLA. È innocente, v'assicuro.

LINDORO. La mia fede a voi prometto.

DRUSILLA. Io vi tengo stretto stretto.

BELFIORE. Oh che gioia, oh che diletto!

DRUSILLA, BELFIORE e LINDORO. Che piacere amor mi da!

Viva viva la bontà! ${ }^{65}$

65 ibid., Act I Finale. Belfiore: My dear! Drusilla: My dear! Lindoro: Listen, sir, listen B: dimwit! [to Drusilla]: Will you be mine? D: If you so wish L: Sir, they are asking for you B: Go to hell, get out of here. D: Oh, hush, quiet now. B: For you, my sweet, I live in pain D: and I love you very much L. (looking out): Yes sir, he's on his way! He'll be right there! B: Whom are you speaking to? D: They are asking for you L: Traitress! D: Imprudent! B: Dimwit, you've tricked me. L: No, in truth, I swear. D: He is innocent, I assure you. L: I promise you my faithfulness 
This comic concertato features quick shifts in meaning, and in the disposition of the characters involved. Two young lovers travel from complicity through mistrust to final reconciliation in the span of a few concise lines, and the old and amorous Belfiore, one minute denouncing trickery, in the next is newly blinded by infatuation. The entire discourse is laden with dramatic irony and traversed by double meanings in constant variation that testify Goldoni's particular comic talent.

In sum, La scuola moderna represents the beginning of Goldoni's work in the dramma giocoso genre, and, however hastily compiled, demonstrates significant dramatic potential that will find fulfillment in later works. Thanks to the clear coexistence of buffo and serio, this work, while of simple design, is able to provide an ample spectrum of dramatic registers and a variety of scenarios, supplemented in their efficacy by the realism and fluidity of action that are a universal priority for Goldoni. From its roots in the intermezzi and the influences of the Neapolitan commedia per musica, the dramma giocoso can now begin to evolve in new directions, guided by the critical instinct and reformist convictions of Carlo Goldoni in mid-century Venice.

D: And I will keep you close to me. B: Oh what joy! what bliss! ALL: What joys love gives me! Long live goodness! 


\section{A new source for Classical opera: Goldoni's drammi giocosi}

Being the first author to venture into a new field did not always bring Goldoni the credit that posterity has bestowed. Navigating a complex theatrical and printing economy towards an uncertain future that ultimately made it impossible for him to remain in Venice, his was by no means a path of linear ascension. Goldoni's writings testify that the burden of innovation at times made writing opera texts an ungrateful task, even an "esercizio sì disgustoso" (disgusting practice). These are the terms he uses in the polemical preface to one of his early drammi giocosi, De gustibus non est disputandum (1754), an 'author's confession' that has often been cited in Goldoni studies as the seal of the author's scarce interest in his musical texts; proof, in other words, of their general irrelevance to his 'real' (prose) comedies and to our approach to him as a literary source.

Yet, a less hasty reading of even this most bitter text yields a different, and much more nuanced, scenario. On the interplay between buffo and serio, for example, Goldoni comments: "Il popolo decide, a seconda dell'esito, se l'opera è a terra, il libro è pessimo. Se è un poco serio, è cattivo perché non fa ridere; se è troppo ridicolo, è cattivo perché non vi è nobiltà." ${ }^{66}$ An opera cannot be too weighty nor too comical; it should create laughter or smiles but without sacrificing its center of "nobiltà." In other words, Goldoni is letting on that the equilibrium between comic and tragic elements in opera, in the mid $18^{\text {th }}$ century, hangs by a delicate thread, and moreover that public taste and sensibility is now seeking a theatre that is neither fully comic nor tragic, but a balanced combination of the two.

Clearly this is easier said than done, especially as no models yet exist for this new type of hybrid work: "Volea pure imparare il modo

66 Carlo Goldoni, De gustibus non est disputandum, Forward. The people decide, according to the success, that if an opera falls, its text is terrible. If it is somewhat serious, it is a bad text because it has no humor; if it's too comic, it's bad because it lacks nobility. 
di contentare l'universale, anche in questo genere di composizioni, ma in sei anni, che la necessità e gl'impegni mi costringono a doverne fare, non ho veduto alcun libro straniero che abbia avuto fortuna e che potesse insegnarmi." ${ }^{97}$ Goldoni clearly kept up to date on the latest theatre, both local and imported, yet in years of 'research' he was not able to find an adequate model to direct him. His own account, which for him obviously had a polemical purpose, for us holds confirmation that he was one of the first dramatists to create, through much experimentation and toil, the foundation of what would become an incredibly successful new genre.

With no promising examples to follow, Goldoni was left to define his own principles on which to create works that could please an exacting audience. Instinctively he turned to comedy, and here is the second important revelation of De gustibus:

Lettor carissimo, se uno tu sei di quegli a' quali abbia io protestato di non volere quest' anno e forse mai più comporre de' simili drammi buffi, voglio anche communicarti la ragione che ad astenermene mi obbligava ed i motivi che mi hanno fatto dal mio proponimento discendere. Il dramma serio per musica, come tu saprai, è un genere di teatrale componimento di sua natura imperfetto, non potendosi osservare in esso veruna di quelle regole che sono alla tragedia prescritte. Molto più imperfetto il dramma buffo esser dee perché, cercandosi dagli scrittori di tai barzellette servire più alla musica che a sé medesime fondando o nel ridicolo o nello spettacolo la speranza della riuscita, non badano seriamente alla condotta, ai caratteri, all'intreccio, alla verità, come in una commedia buona dovrebbe farsi. ${ }^{68}$

67 ibid. I wanted to learn a way of pleasing the universal taste in this type of composition as well, but in the six years that necessity and obligations had forced me to write them, I never saw any foreign example that was well received, that I could learn from.

68 ibid. Dearest reader, if you are one of those to whom I have expressed the desire to not compose anymore comic drammi this year, or perhaps ever again, I want you to know the reasons which compelled me to abstain from them, and the motives that led me to abandon my resolution. Tragic opera, as you probably know, is a theatrical genre imperfect by nature, because it is impossible to uphold any of the rules prescribed to tragedy in it. Comic opera must then be even more imperfect because the authors of these jokes, always seeking to serve the music instead of the comedy itself, and placing their hopes of success in blunt comedy or in spectacle, don't apply themselves seriously to the pacing, to the characters, to plot, nor to truth, as one should do in a good comedy. 
Goldoni was never one to spare criticism, and he certainly doesn't withhold any on the current state of comic opera, which, in his view, invests in the music at the expense of plot and in show at the expense of intrigue. Again, this passage has been read as the author's dismissal of opera in favor of recited comedy, but the distinction to be made is that Goldoni is not referring to his own output, but rather to the "scrittori di barzellette" (writers of jokes) who place the rules of spectacle above those of logic, as he himself never would. Goldoni is in fact denouncing the need for a new vision of comic opera and advocating respect for character development, plot, and truth, in sum all the elements essential to good comedy.

Naturally, no one will deny that, based on his terms, Goldoni at the moment of De gustibus would have preferred to turn his back on opera theatre. Yet, biographical evidence would suggest that other issues too had played a part in ruining Goldoni's optimism. The shadow of external circumstances is actually made explicit in his Prefazione: "circondato mi trovo dalle più pesanti faccende, al mondo bastantemente palesi." ${ }^{69}$ The date of this text if fact coincides with the closure of his contract with Girolamo Medebach- a contract Goldoni would not renew due to a fierce dispute regarding the printing rights and royalties of the Bettinelli edition (his first major appearance in press), which also saw the disastrous end of their friendship. While Goldoni signed a more advantageous ten-year contract (extended to carnival of 1763) with Antonio Vendramin, proprietor of the Teatro San Luca (today Teatro Goldoni), Medebach hired Pietro Chiari (1712-1785), one of Goldoni's fiercest competitors. The arduous relationship between these two authors was such that it eventually led to a division between supporters of one and the other, chiaristi and goldonisti.

For a time Goldoni was forced, therefore, to put aside his project for realistic Venetian comedy and imitate the styles of his competitors in works of historical or exotic flavor such as Terenzio (Terence), La dalmatina (The Dalmatian Girl), La bella selvaggia (The Savage Beauty), La peruviana (The Peruvian), La sposa persiana (The Persian Bride), etc. The resentment that pervades the preface to De gustibus, an important document in his career as a librettist, is a clear symptom of a greater

69 ibid. I find myself in the most unpleasant circumstances, sufficiently known to all. 
dissatisfaction not only with opera theatre, but with comic theatre in general. Goldoni had clear ideas about the future of comedy, but was plagued by obstacles in realizing his intentions.

In sum, whether curse or blessing, Goldoni was one of the first to begin writing drammi giocosi. And with no direct models for his original operas, he became a true pioneer in the history of the genre.

\section{i. The real world}

Following La scuola moderna, Goldoni authored nearly thirty drammi giocosi alongside his major prose comedies before moving Paris in 1762. Many, if not all, have something to say about contemporary society, customs, or mores, or not rarely a whole list of issues relating to these themes. An eloquent example of Goldoni's 'outspoken' brand of new opera texts is his 1754 Il filosofo di campagna (The Country Philosopher), which calls into question the principles of authority in its portrayal of an intimate relationship between a Countess and her maid. In particular, the interactions of serva Lesbina (parte buffa) and padrona Eugenia (parte seria) progressively consolidate a delicate dynamic of role reversal that is evident from the opening scene:

LESBINA. Io vi offerisco quel che so, quel che posso. È ver che sono in una età da non prometter molto; ma posso, se m'impegno, par valere per voi l'arte e l'ingegno.

EUGENIA. Cara di te mi fido. Amor, pietade per la padrona tua serba nel seno; se non felice appieno, almen fa' ch'io non sia sì sventurata.

LESBINA. Meglio sola che male accompagnata. Così volete dir; si si, v'intendo. EUGENIA. Dunque da te qualche soccorso attendo. ${ }^{70}$

70 Carlo Goldoni, Il Filosofo di Campagna, Act I, i. Lesbina: I'll do for you what I can, what I know how. Perhaps I can’t promise too much at my age, but I can, if I set my mind to it, make good use of art and wit. Eugenia: My dear, I trust in you. Keep love and mercy for your mistress in your heart. If I cannot be truly happy, at least let me not be so unfortunate. L: Better alone than in bad company, you mean. Yes, yes, I understand. E: Then I will await your assistance. 
In the manner of his prose comedies, Goldoni develops numerous realistic characters, among them Lesbina and the Countess. The buffa Lesbina is, or course, materially impoverished and of humble state, but capitalizes on the resources of her mind, "arte" and "ingegno". By contrast, while Eugenia's blue blood bestows social dominance, she is powerless in her own home; her obligations as a daughter subject her to paternal authority and require conventional obedience. She is, consequently, inhibited from taking direct action to establish the future she envisions for herself (i.e. marrying her secret lover and not the country philosopher, as her father intends). Eugenia appears more powerful than Lesbina, but is impotent as concerns what truly matters, and so too is Rinaldo, her aristocratic lover. The musical score by Venetian Baldassarre Galuppi clearly places the two women on the same footing, and from the very beginning. The opera opens with a duet that they share as equal partners; in the musical material assigned to them throughout, they appear more as two friends of equal stature than anything else.

Lesbina, who becomes the serio parts' only means of sidestepping their inhibitions, soon imposes a will of her own. Her authority grows through Acts I and II culminating in complete role reversal, marking $I l$ filosofo di campagna as an ideological precursor of Da Ponte's Le nozze di Figaro (1786). As matters becomes more complex, her language intensifies notably, as for example:

LESBINA. Se de' consigli miei vi volete servir, per voi qui sono. Quando no, vel protesto, io v'abbandono.

EUGENIA. Deh non mi abbandonare, ordina, imponi; senza cercar ragioni lo farò ciecamente; ti sarò non temer, tutta obbediente. ${ }^{71}$

The Countess's helplessness translates to submission, and Goldoni's choice language ("ordina, imponi, lo farò ciecamente") emphasizes a total inversion of roles. Instead of a servant seeking her mistress's

71 ibid., Act II, i. Lesbina: If you want to make use of my advice, I'm here for you. But if not, excuse me, I'm going to leave. Eugenia: Pray don't leave me, command, impose your will. Without asking your reasons I will do it blindly; don't worry, I will be obedient. 
benevolence, we see the exact opposite. Lesbina's decisions alone will ultimately determine the Countess's fate, and not the other way around.

Naturally, the reversed master-servant relationship is a very old topos of comic theatre. Without expatiating upon antecedents of previous centuries, even closer to Goldoni's time 'big hits' such as Pergolesi's La serva padrona (1733) make this clear. In a tradition of theatre that, historically, maintained a marked distance from reality, the overturning of the social ladder within a fictional plot created laughter, not uproar, and while Il filosofo di campagna is closer to a realistic style thanks to Goldoni, we may still relate it partially to that preceding tradition.

Yet, this does not exclude the fact that at the same time (like many of Goldoni's comedies), it reflects the early symptoms of a historical transition. Only one generation later, on the cusp of the French revolution, a servant directing his master would no longer appear quite so laughable. By no coincidence Da Ponte's Le nozze di Figaro caused raised eyebrows in Vienna even after the author had sidestepped censure by purging it of Beaumarchais' radical political content.

Clearly struggles of power and societal influence are ever under the lens of Goldoni's theatre. Yet considering Il filosofo di campagna as a whole, a more positive facet of Enlightenment thought comes to the forefront: human reason. Lesbina's stratagems showcase the power of the mind, and the opera's merry conclusion underlines the happy outcomes of good thinking. Above all the hijinks of Goldoni's work explore and promote intelligence as each individual's most precious possession, and the source of all subsequent material gain.

These notions are instilled within the very title of the opera: Il filosofo di campagna is also the surname of a character within the work (but not the protagonist) known for his reason and thinking. In reality, this 'country philosopher' is only a rustic farmer, Nardo: "ricco riccone, un villano, egli è ver, ma sapientone." ${ }^{.72}$ Despite, or perhaps because of his regressive occupation, Nardo ennobles himself on the basis of the only resource available to him: his own judgment.

72 ibid., Act I, iii. Rich, filthy rich, and a boor, it's true, but a wiseacre too. 
Nato son contadino, non ho studiato niente ma però colla mente talor filosofando a discrezione trovo di molte cose la ragione. E vedo chiaramente che interesse, superbia, invidia e amore hanno la fonte lor nel nostro cuore. ${ }^{73}$

With no education, he capitalizes on reason to draw knowledge from within himself in a facetious Cartesian approach, and benefit from others. It is thanks to his 'philosophizing' that Nardo gains the respect of Eugenia's aristocratic father, and given his assets- mental and material- he will rise so far as to become the father's preferred candidate for his daughter, despite their disparity of rank. Nardo's principal function is to provide comedy, no doubt, and this he does generously through his eccentric nature and laughable erudite mannerisms. Yet it is often said that no joke comes without a basis in truth, and Nardo's new philosophy of life is indisputably an honest one:

Nelle città famose ogni generazion si cambia stato. Se il padre ha accumulato con fatica, con arte e con periglio, distrugge i beni suoi prodigo il figlio. Qui, dove non ci tiene il lusso, l'ambizion, la gola oppressi, son gl'uomini ognor sempre gli stessi. $^{74}$

Goldoni, an author of the Enlightenment, commonly uses country life as a foil for the materiality and corruption of the city, and Nardo's philosophy is no exception. The divergence between the big city and "qui," the surrounding bucolic frame in which the plot unfolds, is largely fueled by issues of material wealth and of appearance. Through Nardo, Goldoni issues yet another condemnation of the profligate ("distrugge $\mathrm{i}$ beni suoi prodigo il figlio"), a new 'mask' of bourgeois society that, unlike Arlecchino or Pantalone, bears many different faces. The prodigal son, who recklessly lives beyond his means in the effort to simulate opulence, becomes a recurring target of Goldoni's libretti and comedies alike not

73 ibid., Act III, ix. I was born a farmer, and I haven't studied anything, yet with my mind, philosophizing well enough, I find the reason behind a great many things. And I see clearly that personal interest, pride, envy, and love, have their source in our very hearts.

74 ibid., Act I, vi. In the big cities, every generation changes status. If a father has accumulated some savings, with toil, with art, and risk, the prodigal son destroys his riches. Here [in the country] neither luxury, ambition, nor gluttony oppress us, and men are instead always them same. 
because of his generosity, an inevitably by-product of his spending philosophy, but for the consuming desire to appear something other than what he is. "Il lusso, l'ambizion, la gola," denounced by Nardo are all inherent vices. And the country philosopher continues along the same lines to target the luxury life more specifically:

Per lo più i cittadini hanno pochi quattrini e troppe voglie e non usano molto amar la moglie. Per pratica commune nelle cittadi usata, è maggiore l'uscita dell'entrata. ${ }^{75}$

Nardo's pert opinions ultimately link material wealth to moral poverty ("non usano molto amar la moglie"), an affliction that erodes the foundations of any truly prosperous society. In conclusion, with Il filosofo di campagna Goldoni not only continues to reflect contemporary life through his targeted critique of materiality and superficiality, but moreover claims reason as an antidote for unawareness or narcissistic illusion. Nardo and Lesbina alike use internal resources to overcome the traditional limits of their lower class standing, and Goldoni's recoup of reason places clear thinking above social condition; mind and will alone enable one to determine his fate, or undergo it.

Il filosofo di campagna, being so developed and multifaceted, is clearly a mature work, yet Goldoni's early texts too were already sufficiently well-crafted as to enjoy a certain enduring success. Il mondo della luna (The World of the Moon, 1750), for instance, was set to music not only by the Venetian Galuppi- one of the highest paid composers of his time (and who set a large portion of Goldoni's texts)- but later by Haydn as well. In regards to this text, along with its chronological neighbors Il paese della cuccagna (The Land of Plenty) and Arcifanfano re dei matti (Arcifanfano King of Madmen), Emery has argued that in his early phase of production Goldoni "abandons realism for an entirely different approach." ${ }^{.76}$ And yet, the utopian realms of these jesting musical comedies are dismantled by the conclusion of

75 ibid., Act I, vi. Most city dwellers have too few means and too many desires, and they are not in the habit of loving their wives very much. As a common practice in cities, the outflow far exceeds the income.

76 Ted Emery, Goldoni as Librettist: Theatrical Reform and the Drammi Giocosi per Musica (New York: Peter Lang Press, 1991); 125. 
each dramma, and total disenchantment occurs among the characters and audience. If 'the land of plenty' is a worldly Eden of food, drink and lovemaking, where both and jealousy are against the law, after two acts these illusions crumble: "voi che in bagordi/male il tempo spendete,/ se vorrete mangiar, lavorerete." 77 The work concludes with an admonition that is quite down to earth: “...vedrà il mondo/ ch'è bella la cuccagna in ogni loco/ ma per proprio destin suol durar poco," with a final chorale "finita è la cuccagna, andiamo a lavorar" that carries a double entendre for the audience, who, at the of a lighthearted evening, must return to their lives, worries, and occupations.

Il mondo della luna is even further from fantasy in that the 'world of the moon' is presented from the very beginning as a man-made illusion, while the plot remains remaining anchored in Venice. Contemporary society is examined and criticized by analogy if not directly, to great satiric effect as the alternative 'lunatic' world, seasoned with the irony of self-recognition, becomes an unforgiving mirror of earthly spectacle. The fake astronomer (Eclittico) makes a great impression on a rich patron (Buonafede) to gain wealth and favors, but discloses his true expertise to the omniscient audience:

Oh le gran belle cose

che a intendere si danno

a quei che poco sanno per natura!

Oh che gran bel mestier ch'è l'impostura!

Chi finge di saper accrescer l'oro

chi cavar un Tesoro,

chi dispensa segreti,

chi parla dei pianeti,

chi vende mercanzia

di falsa ipocrisia

chi finge nome, titolo, e figura,

oh che gran bel mestier è l'impostura! ${ }^{78}$

77 Carlo Goldoni, Il Paese della Cuccagna, Act III , xiv. All of you, who invest your time so poorly in revelry, if you intend to eat, will have to work. The world will see that free-loading is wonderful, but by its own destiny, never lasts long. Our revelries are over, let's all go to work.

78 Carlo Goldoni, Il Mondo della Luna, Act I, i. Oh what wonderful things we can make fools believe! Imposture is a marvelous trade! Some pretend to know how to 
Buonafede's subsequent journey to the moon is nothing more than a false 'ascension' facilitated by sedatives, and a reawakening in an 'alternative world' that is only Eclittico's own garden, where various contraptions have been installed to lend credit to his lie. Heavy irony comes into play as Buonafede's manservant Cecco plays the role of emperor of the moon, and sees his master reverently bow at his feet. The reversal continues as Lisetta the cameriera is made his partner and receives homage from Buonafede's daughters, whom she used to serve. Noteworthy is the rapidity with which Lisetta takes to her new, ennobled state, a transformation underscored by the fact that, contrary to Cecco, she is unaware of the imposture and believes herself to truly be on the moon. The bestowal of power appears to unlock something already within, "Sento nel core un certo vapore/ che m'empie tutta di nobiltà," 79 and quickly grows into overbearing assertiveness:

Olà paggi, staffieri

camerieri, braccieri,

datemi da sedere.

Arricordatevi ch'io son la monarchessa.

Vogl'esser obbedita e rispettata

e se farete ben, vi sarò grata.

Sopra tutto avvertite di nulla riportarmi

di quel che fa il mio sposo.

E null'a lui mai riportar di me,

mentre ognuno di noi pensa per se.

Avete a dormir poco; avete a mangiar freddo

e nell'ore dell'ozio vuò che l'astrologia tutti studiate,

acciò saper possiate quello che far vi tocca,

senza che a comandarvi apra la bocca....

Son io la maestà;

mi metterò in contegno e in gravità. ${ }^{80}$

multiply gold, some to find treasure, others dispense secrets, some talk of the planets, some make merchandise of their own false hypocrisy, others still feign names, titles, and position. Oh, imposture is a wonderful trade!

79 ibid., Act II, x. I feel in my heart certain vapors/ that fill me with noble spirit.

80 ibid., Act III, i. Ho' there pages, stable hands, manservants, workers, give me a seat. Remember that I am the queen monarch. I want to be obeyed and respected, and if you do your job well, you'll have my gratitude. Above all, make sure not to inform me of what my husband does, and never tell him of my doings, for each of 
'Composure and gravity' are all she needs to become a proper noblewoman of the highest order in the eyes of her former superiors. This rovesciamento reconnects to Eclittico's mention of false titles at the opening of the work, and creates an ironic commentary that undermines the connection of haughty mannerisms to any true superiority of intellect or lineage, a signature of Goldonian theatre. The credulity of Buonafede and his daughters, while exaggerated for comic effect, appears to reflect a societal superficiality that judges of an individual from his bearing and on previous assumption, rather than from discernment of his true identity. This problem is hardly a fantastical one, and clearly responds to its own time.

At that, the familiar question of power and social order is by no means the only element of critique in Il mondo della luna; widespread social habits are literally put under observation as Buonafede gazes towards the moon through Eclittico's telescope. What he sees in reality are images projected by a machine, and these become vignettes ripe with implications:
Ho veduto una ragazza
far carezze ad un vecchietto.
Oh che gusto che diletto
che quel vecchio proverà [...]
Ho veduto un buon marito
bastonar la propria moglie
per correggere il prorito
di una certa infedeltà.
Oh che mondo ben compito
oh che gusto che mi dà[...]
Oh che mondo benedetto
Oh che gran felicità! ${ }^{81}$

us can think for ourselves. You must sleep little, eat cold food, and in your hours of rest, I want you all to study astrology, so as to be able to divine what your next task will be without me having to open my mouth... I am the majesty, let me assume composure and gravity.

81 ibid, I saw a young girl flirting with an old man. Oh what pleasure and delight he must be feeling... I saw a good husband beating his wife, to stamp out the 'itch' of a certain infidelity. Oh what a wonderful world, what pleasure it gives me! What a blessed place, what happiness! 
Buonafede marvels at these actions on the moon as if never before seen, yet the irony of the situation is that these customs are not at all foreign to Earth, and furthermore are hardly to be admired. Il mondo della luna is, literally and figuratively, a jesting comic mirror of the earthly world and of universal weakness, and in these elements above all constitutes an exemplary dramma giocoso. It does not, however, contain serio character types or plot lines in the manner of La scuola moderna. Differentiated serio roles instead reappear in Il Conte Caramella of the following year, which Goldoni nonetheless labels a dramma comico, a type we would readily align with the standard tradition of opera buffa. But if serio and buffo together are the hallmark of the dramma giocoso, how do we account for their appearance in a dramma comico?

The interchangeability or occasional ambiguity of terms- which has characterized new musical forms throughout history- is in fact only the natural product of an evolutionary process. We categorize art or theorize music to better describe and understand it, but this becomes possible only after a substantial corpus has been produced. Clearly there was no standardization and little precedent in Venice for the type of comic theatre Goldoni desired. Rather, the author was guided by a gradual change in aesthetic preference, but on the other hand also played a substantial role in shaping that preference, as testified by the challenges he faced in convincing audiences to accept his new approach. The conclusions we can draw from Goldoni's output are thus founded on the characteristics of the overwhelming majority of drammi giocosi, but this is not to say these elements are always exclusive to one genre alone.

Seen in the context of the works that precede and follow, Il Conte Caramella is in fact the exception that confirms the rule; all future works that contain explicit division of parti serie and parti buffe are consistently labeled by Goldoni as drammi giocosi. Il Conte Caramella is exceptional for a more significant reason as well: it is the first of Goldoni's libretti to combine parti buffe, parti serie, and the first-seen mezzi caratteri, an all-important contribution to modern opera theatre. As such, it also serves as an important indicator of the author's creative process. 


\section{ii. The mezzo carattere}

La scuola moderna and Il Teatro Comico teach important lessons about balance between comic and tragic in theatre, yet this is not to imply that the coexistence of buffo and serio is a Goldonian invention, or even an invention of the $18^{\text {th }}$ century for that matter. Clearly it was foreseen, in some measure, by the older tradition of improvised comedy, which in fact drew some of its juiciest skits from the interactions of amorosi (titled roles, i.e. prototypical parti serie) and masked characters (as for instance Arlecchino servant of two masters). The true novelty at hand in Goldoni's time is not their mere existence, but their transformation as these become an integral part of his new comic theatre, and new musical theatre by extension.

At a time of transitions in Goldoni's life, just as he is severing his bonds from Medebach and transitioning to the Teatro S. Luca, and- for his musical texts- to the Teatro S. Samuele under the direction of Grimani (one of the many advantages of his new contract with Vendramin was that it was no longer exclusive), Goldoni creates his first mezzo carattere for opera theatre, a figure which, in some way, his very first dramma giocoso already defined. Il Conte Caramella will in fact give spectators "materia buffa... intrecciata colla seria," no longer just in parallel plot lines, but now within a single character.

The centrality of character identity to Goldoni's theatre is difficult to overstate. Clearly, much unlike those of some of his contemporaries, his comedies are not about action or distraction, nor spectacle or play; we don't approach his texts to travel away from reality, or to put a damper on what's on our mind. A spectator or reader will choose a Goldonian comedy because they want to get to know, gradually but intimately, real individuals; Mirandolina, Lelio, Sior Todaro, Anzoletto and many others are characters so complete in their depiction, so lifelike in their originality, as to almost transcend the - in retrospect almost circumstantial- plot scenarios in which they are made known.

The diligent reader of Il Teatro Comico, Goldoni's meta-theatrical commentary on his own approach to theatre, will recall the appearance of two new figures that don't quite fit in with the rest of the troupe: an author who previously scraped by writing skits for the Commedia 
dell'Arte, and a singer of dubious skill who performed intermezzi and farces (this we gather from the Didone in bernesco cited repeatedly as her only 'success'). Both arrive penniless and hungry, unemployed because times have changed and their trades are being replaced. These two figures lie outside the traditional roles of the theatre company, and are neither mask nor leading role.

As we trace the mezzo carattere through Goldoni's texts for music, then, it is useful to keep in mind that, just as he begins to sketch these new musical characters, he is also building his commedie di carattere from the central idea of character identity, which, exactly like the mezzo carattere is miles away from jest or declamation, and testifies the search for a calibrated medietas which will affirm itself ever more markedly in his theatre, hand in hand with sentimentalism.

In Il Conte Caramella the mezzi caratteri are in fact two, though the role of the protagonist is, predictably, more developed. They are listed explicitly in the frontespiece situated between serio and buffo characters.

\author{
SERI \\ LA CONTESSA OLIMPIA moglie del conte Caramella \\ IL MARCHESE RIPOLI di lei amante \\ MEZI CARATERI \\ DORINA giardiniera della contessa \\ IL CONTE CARAMELLA creduto morto, in abito di pellegrino
}

\title{
BUFFI \\ GHITTA serva rustica della contessa \\ CECCO contadino di lei amante \\ BRUNORO contadino e tamburino di truppe suburbane
}

This work, set to music by the celebrated 'Buranello' (this was how Galuppi was affectionately known in Venice, being that he came from the island of Burano), is structured on different plot lines that converge, as usual, at the conclusion. The main plot appears to shadow the Homeric Odyssey in comic and cosmopolitan garb: Count Caramella, rumored to have been killed in battle, returns to his estate disguised as a soothsayer and discovers a Marquis relentlessly courting his wife. The Contessa, like a modern Penelope, hopes against all odds in her 
husband's return and remains faithful, but is surrounded by lies and put under pressure by her suitor. Interestingly, Goldoni's source of inspiration in this case was actually a much more modern text, Joseph Addison's 1714 comedy The Drummer, or the Haunted House. Goldoni's libretto is openly imprinted on Addison's original preserving the signature trait of its title: the Marquis, in the hopes of leading the Contessa to accept him as a second husband, has a servant pound a war drum at night, which everyone takes to be the ghost of the deceased Count.

The linguistic differentiation of serio and buffo roles in this work is not unexpected, but Goldoni does create novelty in developing a personal, psychological dimension entirely absent from Il mondo della luna and other preceding works. The deepening of his characterization is most evident in the role of the Contessa, whose character and circumstances are complex. Continually suspended between rumors of her husband's death and hope of their falsehood, her doubt and confusion are realistically portrayed by Goldoni in a scene with the insistent Marquis:

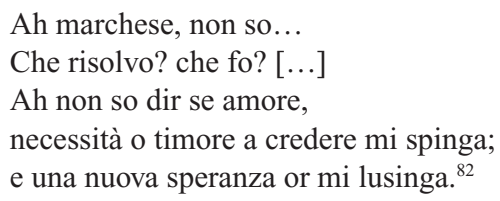

The spontaneous quality of these fragmented lines realistically portrays a state of emotional confusion. The 'new hope' to which the Countess refers is also ambiguous; while the Marquis interprets it as the first signal of a change of heart in his favor, the Contessa later denies any intention of accepting a new companion:

Ah, ch'io d'errar pavento

e non ho core d'abbandonarmi

a nuovi affetti in preda;

par ch'estinto il consorte ancora non creda. ${ }^{83}$

82 Carlo Goldoni, Il Conte Caramella, Act II, ii. Ah Marquis, I don't know... what should I decide? what should I do? ... Ah I don't know if it be love, or need, or fear that spurs me to believe; and a new hope now flatters me.

83 ibid., Act II, iii. Ah, that I am afraid to commit error and have no heart to give myself over to new affections; it would seem that I don't yet believe my husband dead. 
Especially noteworthy is Goldoni's detail, "par ch'io creda," a small nuance in wording but one that shows a character surprised by her own instincts, and who, in her confusion, is looking in on her own feelings almost as an outsider.

Along with newly-honed psychological elaboration, the true groundbreaking element of Il Conte Caramella is of course the first appearance of two mezzi caratteri, the Count himself and a servant-girl, Dorina. An absolute novelty, therefore, is the adaptability of this character type to figures of any social extraction. But in what way, then, do these roles distinguish themselves from the others? Dorina, who in origin would fulfill a parte buffa, does not elevate her character through refined language or honorable conduct, but, as an accomplice to the Marquis, atypically assumes a leadership role amongst her fellow servants. The difference between her and her peers is thus not a question of style but rather of influence, an aspect of her character promptly highlighted by Galuppi, who assigns her surprisingly virtuosic arias, duets, and ensemble pieces. Just as Dorina's role is invested with greater responsibility, the Count's is lightened with comedy, largely afforded by his disguise (but - between the lines- likely also deriving from that excess of jealously that pushes him to such lengths to spy on his wife).

The new flexibility of the mezzo carattere is a far cry from its serio male counterpart, the role of the Marquis. The latter is characterized, not surprisingly, by markedly elevated language ("Ma, se ardirai cotanto, ignorante, impostore, proverai tu il mio sdegno e il mio furore. Cessa di provocarmi, trema dall'ira mia," ${ }^{84} \mathrm{etc}$.) that is actually caricaturized in music through exaggeratedly long melismas, high notes, and dotted rhythms- a parody corroborated by the fact the Marquis' part is written in the soprano register. At its Venetian première it was performed by a castrato of a certain fame, Salvatore Consorti- and indeed the part is so virtuosic as to require a professional, certainly beyond the reach of the actors who sang intermezzi. In subsequent premières in Trieste (1753, Teatro di S. Pietro) and Milan (1756, Teatro Regio Ducale) the role was taken by women in

84 Carlo Goldoni, Il Conte Caramella, Act III, ii. 
cross-dress, which must have inevitably further accentuated the affectation of this dandy figure.

Caramella instead at times takes on the semblance of the parte seria, sharing linguistic and musical elements with the Marchese, but at other times becomes the principal source of comedy. The musical score reflects this in the reduction of his solo arias in favor of shorter pieces and ensembles, one of Goldoni's strategies for realism that will have a long legacy through opera history. A particular novelty in this sense is the following scene (II, iv) between the Count in disguise, his wife, and the second mezzo carattere Dorina:

CONTE. Orsù perché crediate

ch'esser possa il futuro a me svelato

qualche cosa dirovvi del passato.

Pria d'essere sposata, il conte capitano

vi prese per la mano una mattina.

Fuggiste modestina, vi vergognaste un poco

ma vi ridusse in loco solitario.

Diceste: «Temerario, andate via di qui», movendo in dir così la bocca al riso.

Ed ei con un sorriso amante pronto e scaltro...

CONTESSA. Basta così, non voglio sentir altro.

DORINA. (Come è venuta rossa). (Da sé)

CONTESSA. (Io non so come ei possa queste cose sapere per minuto). (Da sé)

DORINA. (Questo brutto barbone è molto astuto). (Da sé)

CONTE. E ben, vi contentate

che contro questo spirto

usi il poter sovrano?

DORINA. Non gli badate, ch'egli è un ciarlatano.

CONTE. Io sono un ciarlatano? Sfacciatella,

io ti farò cambiar sensi e favella. 
Rammenta quella borsa
che tu dal conte avesti
allora che facesti la mezzana.

E cosa non è strana, se tu procuri adesso

di fare ancor lo stesso col marchese.

Il tutto mi è palese

e so che un regaletto...

DORINA. Basta così... (Che tu sia maledetto). (Da sé) ${ }^{85}$

No longer isolated like a traditional aria, the Count's solo part is embedded within a course of action that never stops progressing. Goldoni achieves something truly novel: a hybrid piece, part solo aria, part ensemble (the other voices carry only recitative), built on a text without a single repetition or refrain, and inserted right in the middle of the act, not towards the end. To this we add, of course, the interweaving of various levels of conversation: the women speak amongst each other, the Count to each of them separately, and each has lines "a sé" (to themselves) for the audience. Strategies like these are targeted towards diversifying the content of opera scenes, and testify how Il Conte Caramella constitutes a definite step forward in the direction of a new, modern, and realistic equilibrium between buffo and serio, and in fact their total fusion in the mezzo carattere.

Not surprisingly, the Count's playful part- and the music that accompanies it- gives way to an entirely different style and bearing once he reclaims his rightful place as husband: "Vattene, scellerato, il piacer di trovare/ una sposa fedele a questo segno/ tutta mi fa depor l'ira e lo

85 Carlo Goldoni, Il Conte Caramella, II, iv. Conte: Alright then, to prove that I can foretell the future, I shall tell you something of the past. Before you were married/ the Count, a captain/ took you by the hand/ one morning. You fled in modesty/ you were a bit ashamed/ but he led you/ to a solitary place. You said "You are too bold/ go away at once"/ but while speaking, moved your lips/ to laughter. And he, with a smile,/ as a quick and artful lover... Contessa: That's enough, I want to hear any more! Dorina: (Oh look how she's turned red) (aside). 
sdegno." ${ }^{96}$ With his authority returned to him, he not only changes tone and expression, but also displays the clemency of a true noble spirit. His elevation from beggar to ruler takes him from mezzo carattere to full parte seria. In this light, the particular connection of dramatic role to social status appears fully consolidated: in other words, serio and buffo roles are, at this early stage, unequivocally tied to characters of high and low extraction. Yet even with the idiosyncrasies of opera theatre, Il Conte Caramella testifies that realism is the primary concern of our author, who doses comic and serio with nuanced moderation, and promotes their coexistence in the transformative mezzo carattere.

Looking ahead, we find other important milestones in the evolution of the mezzo carattere in Goldoni's later drammi giocosi. It was, in fact, precisely the delicate balance between tragedy and comedy, gravity and lightness, that sealed the international and enduring success of Goldoni's most famous mezzo carattere, Cecchina from La buona figliuola ("The good girl", 1758). Goldoni drew this text from his comedy of eight years prior, La Pamela, a re-creative process examined later in more detail. This comedy, together with its first actress Teodoro Medebach, had already attained inordinate success, and largely thanks to the sentimental coloring of the script. Records attest that when first introduced it was immediately replicated for 18 consecutive nights, a number that is truly extraordinary for the rich and competitive Venetian circuit that generally sought new works daily. Outside of Venice its success was by no means inferior, drawing audiences for many nights at the Roman Teatro Capranica and other venues, such that in his Mémoires a proud Goldoni writes, "da sola [Pamela] sostenne il teatro dall'apertura sino a martedì grasso." ${ }^{\text {"W }}$ When deriving his dramma giocoso (set to music by Fischietti in 1758 and by Piccinni in 1760) from this 'character comedy,' Goldoni attentively preserved, and even enhanced, the sentimental dimension of his mezzo carattere. Paolo Gallarati has viewed this opera as the precursor to opera semiseria ${ }^{88}$ for these reasons, and

86 ibid., Act III scena ultima. Begone, wicked man, the pleasure of finding/ a wife so faithful/ brings me to set aside my rage and scorn.

87 Carlo Goldoni, Mèmoires, vol. II Ch. 38.

88 “... [La buona figliuola] inaugurava il filone dell'opera semiseria destinata a rappresentare in seguito, praticamente sino a Rossini, una valida alternativa 
whether or not this be true, it certainly embodies a significant step forward in the direction of realism and psychological depth.

Cecchina and her Marchese, the two mezzi caratteri of this work (serva and padrone just as in Il Conte Caramella), are immediately distinguishable the rest of the cast through their intermediate position within the character list on the frontespiece, but also by their conduct. The two parts, and the role of the protagonist in particular, are miles away from the parti serie who continue in an older Metastasian vein. In Pamela, Count Ernold objects to Bonfil: «Se andate a teatro, ove si fanno le opere musicali, vi andate solo per piangere, e vi alletta solo il canto patetico, che da solletico all'ipocondria». ${ }^{89}$ This decidedly modern disposition is clearly discernable in the tearful yet calibrated mannerisms of the operatic protagnist Cecchina, not without hints of comédie larmoyante, such that for Anna Maria Finetto, "proprio da Cecchina inizia, sotto certi aspetti, la moda del canto patetico che si svilupperà nell'opera seria romantica. ${ }^{\prime 90}$ While the delicacy and changeability of Goldoni's mezzo carattere appears wholly antithetical to the tragic roles of Romantic opera, it is true that later musical tradition will continue in the direction of psychological realism. In this light, and as we will see in the following chapters, Goldoni's contributions reach far beyond his time.

The product of an experienced hand, it comes as no surprise that in La buona figliuola the process of linguistic simplification essayed in $\mathrm{Il}$ Conte Caramella is applied much more markedly. Cecchina's concise phrases and unornamented language are in complete harmony with her simplicity and naiveté:

Vo cercando e non ritrovo

la mia pace e il mio conforto,

alla radicale opposizione dei due generi principali." Paolo Gallarati, Musica e Maschera, Torino, EDT, 1984, 135.

89 Carlo Goldoni, La Pamela, I, xvi. If you go to theatres where they perform opera, you go only to weep, and you draw pleasure only from pathetic song, which feeds your imaginary illnesses.

90 "Cecchina marks the beginning, in some ways, of the fashion for sentimental song that would later develop into Romantic opera." A. Finetto, La Pamela e La Buona Figliuola: Il Linguaggio Patetico di Goldoni, «Studi Goldoniani», VIII, PisaRoma, Fabrizio Serra, 1988, p. 107. 
che per tutto meco porto

una spina in mezzo al cor. ${ }^{91}$

Strangely enough, by comparison it is Pamela who appears more formal and less realistic, notwithstanding the greater liberties afforded by her prose part in comparison to the added complications and constraints of the musical role:

Oh Dio! Che è mai questo nuovo tremor, che mi assale le membra! Ahi che vuol dir questo gelo, che mi circonda le vene! Oimè, come dal gelo si passa al fuoco? Io mi sento ardere, mi sento morire. ${ }^{92}$

Even when she invokes death, Cecchina is more moderate, more tender:

Almen fra queste piante

avrò un po' di riposo.

Ah son sì stanca di sofferir

gl'insulti della nemica sorte

che son costretta a desiar la morte..$^{93}$

Piccinni's musical setting certainly indulges in the sentimental potential of her role. Her aria "Una povera ragazza" (I, xi) is an excellent example of how, even when the text could suggest stronger feelings, such as anger ("Una povera ragazza/padre e madre che non ha/ si maltratta si strapazza/ questa è troppa crudeltà" ${ }^{\prime 4}$ ), he chooses instead to underscore at once her admirable stateliness and tender vulnerability. While the text is rhythmic enough to suggest a lively setting in dotted rhythms, Piccinni's aria is instead an Andante marked piano assai, and in addition to the slow tempo and linear melody (with a few expressive

91 Carlo Goldoni, La buona figliuola, I, xvi. I seek but I can't find/ neither peace nor comfort/ and everywhere, I carry/ a thorn within my heart.

92 Carlo Goldoni, La Pamela, III, xi. Oh God! What is this new tremor that seizes me! What is the meaning of this chill that surrounds my veins! Ah, how is it that from such cold I pass to fire? I feel myself burning, I feel myself dying.

93 Carlo Goldoni, La buona figliuola, II, xii. At least amid these plants I may find some respite. Ah I am so weary of suffering the blows of my enemy fate, that I am forced to desire death.

94 ibid., I, xi. A poor girl/without mother or father/ is mistreated and vexed.../it is too cruel. 
leaps) the composer also meanders in and out of the minor mode at key moments ("Partirò...me ne andrò", etc.), and lingers through repetition.

The pathetic nature of Cecchina's role is not only evident through her language (self-pitying adjectives- "povera", "poverina," etc.- are everywhere), but more broadly in the irony of the events that befall her. Goldoni- and Piccinni- make extensive use of the ensemble finale in this dramma giocoso, using expansive group pieces as a vehicle for plot development. Elements of larmoyant often surface in these scenes, as for example the finale of Act I, in which Cecchina is portrayed as an innocent victim. Banished by her Bonfil because he believes her indifferent to him, and by her faithful friend Mengotto because of jealously, Cecchina is also attacked in spite by servants Sandrina and Paoluccia, who, envious of the attentions she receives, plot to undermine her reputation. Cecchina's repeated interjections, "Chi mi aiuta, per pietà?" create a sense of pleading urgency and enhance the pitiable tenderness of the scene. Further pathos in Goldoni's dramma giocoso is afforded by an original scene of abduction, absent from La Pamela, in which Cecchina is put under arrest by a parte seria, the Cavaliere Armidoro (Act II). Franco Fido's observation, "il dramma per musica può accogliere una dimensione romanzesca e avventurosa negata alla commedia," appears relevant in this respect.

Notably, the tender moderation of this mezzo carattere does not falter even in light of happy deliverance at the work's conclusion. Through a coup de scène Cecchina is revealed to be of noble birth, receiving both aristocratic status and the hand of her beloved. And yet, her reaction is one of interior conflict:

\footnotetext{
Ah signori, vorrei

far i doveri miei;

ma ho ancora il cuore

fra la gioia confuso

e fra il timore. ${ }^{95}$
}

Not exaltation nor triumph, but realistic incredulity and self-consciousness color this 'good girl's' apotheosis. Goldoni chooses to underscore her modesty and sensibility through to the end, which Piccinni supports through a lyrical ending. La buona figliuola is a gem of neoclassical

95 ibid., III, xi. 
sentimentalism, reason for which, in the words of Daniel Heartz, it was an opera "destined to surpass all his other librettos in the influence it yielded." ${ }^{\prime 6}$ Above all, Cecchina exemplifies the versatile dramatic potential of the mezzo carattere, which, expressing even the strongest emotions with simplicity, preserves their purity and power.

The two examples examined thus far bear testimony to the way in which, when they are present, mezzi caratteri readily take on a protagonist's role. The expansive expressive range and changeability of this figure certainly could not be equaled by a traditional parte seria or buffa. The mezzi caratteri clearly facilitate, if not guarantee, interest within the plot, reason for which, when they are present, they are placed right at the center of events.

Beyond Caramella and Cecchina, many others still color the pages of Goldoni's drammi giocosi. The careful reader may glean their presence from their conduct and expression, as for example in Le nozze in campagna (1768), or find them again explicitly set apart in the character lists, as is the case for Il Re alla caccia (1763, Galuppi's almost $100^{\text {th }}$ opera). This later work in particular testifies how the role of the mezzo carattere takes on wider dimensions at every new appearance; the two mezzi in this case are no longer servant and master, but two men divorced from any romantic intention: one a courtier, the other King Henry IV himself. Clearly a great disparity of status still stands, yet, in the dark of night in the woodlands, where the plot begins, their status is, if not equaled, certainly leveled significantly- especially when the King, having lost track of his hunting party and lost his horse as well, loses his habitual superiority as well:

Ah in sì fatal momento

veggio quanto si accosta

al più vil de' mortali un re possente.

Non va un monarca esente

dal timor, dal dolor; finché sul trono

siede il sovrano, ai sudditi prevale;

quando è solo in un bosco, agli altri è eguale. ${ }^{97}$

96 Daniel Heartz, Goldoni, Don Giovanni and the Dramma Giocoso, "The Musical Times" 120-1642, (London: Musical Times Ltd., 1979); 994.

97 Carlo Goldoni, Il Re alla caccia, II, i. Ah, in such fatal moment I see how close a powerful King is to the lowest of men. No monarch is spared fear, nor pain; on the throne he may sit above his subjects, but alone in the woods, he is equal to all the others. 
He will be led to shelter by local farmers, who, ignorant of his true identity, will treat him with directness and sincerity, gaining his goodwill and benevolence in so doing. The events that befall the King, who, if not explicitly disguised like Count Caramella still does lose his identity for a time, denote how, in addition to the advantages to plot and to sentimental depth it brings, the mezzo carattere lends itself particularly well to the treatment of the most important contemporary social issues- among these the struggle of rationalistic, Enlightened thought to reconcile ideas of individual merit with the hereditary mechanisms of a still aristocratic class structure. Merit and title, blood and conduct, appearance and substance are difficult dichotomies that Goldoni's libretti thrive on. The King's words, in fact, repeat the same messages written time and again by our Venetian author, as for example,

Signor, vi parlo schietto

Tutti nudi siam nati,

Tutti nudi morremo;

Levatevi il vestito inargentato

E vedrete che pari è il nostro stato ${ }^{98}$

or

Per me sostengo e dico

Ed ho la mia ragione

Che sia la condizione un accidente.

Sposare una servente

Che cosa importa a me se è bella e buona?

Peggio è assai, se è cattiva, una padrona. ${ }^{99}$

among many others. The conclusion of Il Re alla caccia is one further installment of Goldoni's systematic scrutiny of 'virtue,' given that the

98 Carlo Goldoni, Bertoldo, Bertoldino e Cacasenno, I, iv. Sir, I will speak frankly. We were all born naked, and naked we shall all die; if remove your silvered robe, you'll see that we are equal.

99 idem, Il Filosofo di Campagna, II, xiv. I believe and proclaim- and I am right to do so- that class is nothing but luck. Why should I care if the girl I marry is a maid, if she is beautiful and good? A mean Lady would be much worse. 
simple woodsman who rescued the King will be rewarded with a title of nobility, but just as soon as he receives it "la stessa virtù diventa orgoglio"100 (virtue turns to pride); ambition and desires poison his happiness. His natural well-being is restored only renouncing the illusion of social ascension to reembrace the simple life, a cardinal lesson of Goldoni's theatre.

Without meandering further into a comprehensive catalog of Goldoni's mezzi caratteri in opera, it is important instead to understand the kind of impact this new figure went on to have on the state of the art. Mozart's operas, as we will see more specifically later on, are one witness to how the broad spectrum of character types and dramatic strategies developed and consolidated by Goldoni had become, two generations later, common practice. Goldoni's principles were, to use Da Ponte's term, "domma teatrale" (theatrical dogma), and the mezzo carattere was part of this inheritance- proven not only by the content and structure of Mozart's operas, but also, and explicitly, by his correspondence. In 1783 Mozart was searching for a new opera libretto, and laid out the following criteria to his father Leopold:

(...) das nothwendigste dabeÿ aber ist recht Comisch im ganzen - und wen es dan möglich wäre 2 gleich gute frauenzimer Rollen hinein zu bringen. - die eine müsste Seria, die andere aber Mezzo Carattere seÿn - aber an güte - müssten beÿde Rollen ganz gleich seÿn. - das dritte frauenzimer kan aber ganz Buffa seÿn. ${ }^{101}$

Within the span of a few decades, clearly, the mezzo carattere becomes an integral part of comic opera theatre, internationally. Beyond this, we can also observe how, if the first mezzi caratteri, like Count Caramella, were decidedly more comic than tragic, through its evolution this figure progressively gains prominence and depth, such that Mozart places it

100 idem, Il Re alla caccia, I, ix.

101 W. A. Mozart, letter to Leopold Mozart (Vienna, 7 may 1783), Siftung Mozarteum Salzburg, Digital Mozart Edition [www.mozarteum.at]. The most important thing is that the story, on the whole, be truly comic, and, if possible, the author ought to introduce two equally good female parts; one must be Seria, the other Mezzo Carattere, but both roles must be entirely equal in quality. The third female character, however, may be buffa. 
on the same plane as the parti serie, while the parti buffe by comparison appear ancillary, and not indispensable.

The changeability of the mezzo carattere, who can move seamlessly from light comedy to deep sentiment, is no doubt its most important realistic advantage, one destined to become ever more dominant in the second half of the century, in correspondence with growing appreciation for the psychological dimension of theatre, along with the growing fashion of sentimentalism and larmoyant. The mezzo carattere is one of many ways in which the general aesthetic preference for 'truth' of the age of Enlightenment gives rise to creative artistic solutions. Goldoni's particular contribution to the creation and consolidation of this figure, and its centrality to the development of his 'character comedies' as well as to his musical works, is a topic of research that can supply a missing piece of the puzzle- not only as regards his own theatre- but more broadly in the frame of opera history.

In the mezzo carattere we find that lifelike balance that animates Goldoni's most successful characters and captivating scenes. In his own words,

Per me nessun personaggio è inutile. Ciascheduno ha qualche particolare, che può servire il teatro; chi più, chi meno, egli è vero, ma i mezzi caratteri son necessari ancora, come le mezze tinte ai pittori. ${ }^{102}$

\section{iii. Buffo, serio, and the space between}

From 1751 onwards Goldoni wrote exclusively drammi giocosi until his move to Paris eleven years later, along with prose comedies, as ever in high demand. The sheer volume of texts produced during this 'mature' decade is impressive: excluding the sixteen new comedies of

102 Carlo Goldoni, Preface to La Gastalda. To me no character is useless. Each has some particular that can be useful to the theatre; some more, some less, it's true, but the mezzi caratteri are necessary too, just as halftones are necessary to painters. 
that famous- or infamous- $1750-51$ season, he added nearly 80 original works for the prose theatre and more than 30 drammi giocosi to his repertoire, many representative of an evolving discourse between buffo and serio.

While Il Conte Caramella formally separated buffi, seri, and mezzi caratteri, this practice is not taken up again by Goldoni before 1754, after which it is applied with some consistency, beginning with Galuppi's Il filosofo di campagna of that year. This work brings a good dose of social commentary, as we have seen. Yet within it Goldoni also presents another small innovation in the relationship of buffi and seri, in particular through his treatment of the character Don Tritemio. Galuppi sets him as a bass-baritone no doubt because of his age, yet while Eugenia's heart is naïve but pure, her aristocratic father is plagued by flaws. Avarice and a weak mind spur him to give Eugenia in marriage to a man he considers a "villano," for example. Corrupt and unable to sustain a parte seria with rectitude, the final surprise of Il filosofo di campagna is that this character, while an aristocrat, is relegated to parte buffa. Goldoni thus commences eroding the boundary between buffo and serio relatively early in his career.

In structural terms, furthermore, the most noteworthy element of this opera is the continued expansion of ensembles. To cite just one example, the conclusion of Act I features an extended ensemble finale with the peculiarity of rapid action interpolated throughout. While several characters are continually present, Goldoni creates a circular chase between Lesbina and Don Tritemio, who enter and exit continually. A masterfully entangled situation intensifies as Lesbina, in the guise of Eugenia, accepts attentions and ultimately a wedding ring from Nardo, but at each advance feigns modesty and flees when Don Tritemio approaches. Don Tritemio in turn, who believes the fleeing figure to be his daughter, fruitlessly searches for her while becoming ever more disoriented, in an exiting pace the music accentuates with ease.

Questions of social rovesciamento continue in Li pazzi per amore (The Mad for Love, 1754, set in Livorno, first musical score by Cocchi) and $I l$ povero superbo (The Proud Poor Man) 1755, set in Bologna, score by Galuppi but now lost). Both premiered at the Teatro San Samuele, both formally separate buffo and serio roles, and both, not surprisingly, continue to pursue relevant themes in their content. Without 
entering into the texts, therefore, it may suffice to recall that in the first opera, the serio prima donna (again named Eugenia) is from the start disguised as a servant girl, while by contrast Il povero superbo targets a protagonist of lowly origin made wealthy by inheritance. Aptly named, Il Cavaliere dal Zero is "reso miserabile dal fumo della nobiltà." 103 Goldoni thereby adds yet another facet to his playful critique of nobility with weak foundations.

We find a more significant step forward in Le nozze (The Wedding) of the same year, set again by Galuppi for the Teatro Formagliari in Bologna. Unlike its predecessors, this work does not separate parti buffe from parti serie in the character list. In fact, Goldoni will suspend this practice until 1758, though the divisions remain implicit through class differences and mode of expression, as later works will demonstrate. In the case of Le nozze in particular, however, the lack of definition of the parts is a commentary in itself, as the boundaries between buffo and serio are progressively attenuated. In this work, the aristocratic characters do not suffer from the want of power that Goldoni elsewhere has shown, but do not preserve the mannerisms of a parte seria. Rather, the author injects a significant dose of realism in their frankness as they often lose their composure. In the same way, their servants and attendants take on the leading roles, and display some elements of serio in mezzo carattere as we shall see.

The opera opens with a Count and Countess in vehement argument. Their exchanges have replaced Metastasian grace with pragmatism, and the rapidity of the discourse is rather typical of a buffo scene:

CONTE. La voglio così.

CONTESSA. Così non sarà.

CONTE. Prevale il mio sì.

CONTESSA. Stavolta non già. ${ }^{104}$

Goldoni thus enters immediately into the quotidian reality of marriage in its least gracious aspect, marking the work from the beginning as an

103 Carlo Goldoni, Il Povero Superbo, elenco dei personaggi. (...) rendered miserable by the smoke [illusion] of nobility.

104 Carlo Goldoni, Le Nozze, Act I, i. Count: I want it this way. Countess: It won't be this way. Count: My ‘yes’ will prevail. Countess: Not so quickly, this time. 
exercise in realism. Most unusually, the dispute between the two noble characters is carried to a point of extreme aggravation that culminates in the drastic and mutual resolve to end their union. While preparations are made to summon the notary, the tone remains dry and practical:

CONTE. Come dissi, d'ogni effetto dotale

che portò la contessa in questa casa,

preparatemi i conti. (...)

CONTESSA. Badate; nel contratto vi ha da essere un patto,

per cui nel caso di restituzione,

s'han da considerare i frutti ancora.(...)

CONTE. Poi penseremo a sciorre il matrimonio.

CONTESSA. Liberata sarò da un tal demonio. ${ }^{105}$

Only away from her husband does the prideful Contessa transform her rigid expression into a softer poetic language that reflects tones of melancholy and tenderness. Her first solo aria is one of reflection on surpassed and ephemeral love, which, nonwithstanding Galuppi's somewhat 'indignant' dotted rhythms also creates a scene of pathos dramatically different from the action that precedes and follows:

Per una serva il marito di me fa poca stima?

Ah dove, dove andò l'amor di prima?
Ah dove è andato
quel primo affetto?
Ah che l'ingrato
mio sposo in petto
cangiato ha il cor.
Duran per poco
quei primi istanti;
si spegne il foco,
cessa l'ardor. ${ }^{106}$

105 ibid., Act II, scene iii. Count: As I said, I wish that accounts be prepared for everything the Countess brought in dowry to this house. Countess: Be careful; in the contract there must be an agreement, that in the case of restitution, interest accrued must also be considered. C: Then we shall see to dissolving this marriage. C.ss: I will be freed from such a demon.

106 ibid., Act I, ii. For a servant girl, my husband esteems me so little? Ah where, where is the love we first had? Ah, where has that first affection gone? Ah, my 
The character's subdued reflections suspend her intimate musings within a moment of stillness and respite from the hurried external events. Her text is colored by the nostalgic hues of recollection and longing for the affection now lost. These elements, together with the fact that the source the Countess's grief is her husband's interest in a lively, intelligent servant girl, cannot but remind us once again of Da Ponte and Mozart's masterful Le nozze di Figaro. The above text in particular rings as a clear precedent for the famous "Dove sono i bei momenti" aria of that opera, written forty years later, though the musical penchant is undoubtedly different. Comparison of the two scores would appear to exclude any 'borrowing,' much less direct transposition, but attests that Goldoni's tendency towards psychologically-attuned and realistic serio content within comedy was, as yet, ahead of his time and had a lasting continuation in the operatic tradition.

Not unlike what occurs in Le nozze di Figaro but also in Goldoni's preceding Il filosofo di campagna, when the aristocracy becomes ill-adept at conflict resolution, an intelligent and tactful servant takes charge of the action. In the case of Le nozze, the Count and Countess are hindered by their own pride, thereby requiring the aid of Goldoni's proto-Figaro character, Masotto (also a baritone), who steps in to (quite literally) bend the unyielding Count and Countess towards reconciliation:

MASOTTO. Via, s'accostino un poco.

CONTESSA. Oh questo no; la prima non sarò.

MASOTTO. Da bravo, padron mio.

CONTE. Non voglio essere il primo ne' men io.

MASOTTO. Un pochino alla volta. Un pochino per uno.

Vi è un po' di ritrosia; con licenza, signor, anderò via.

Servo umilissimo, ossequiosissimo,

quando mi chiamino sarò prontissimo,

verrò a servir.

Faccia un passo in là; (all'uno)

volti quel viso in qua (all'altro)

Ah che contento amabile, quando due sposi s'amano,

il cuor che d'ira è torbido in pace ritornar. ${ }^{107}$

ungrateful husband has changed his heart. Those first moments are fleeting; then the flame burns out, the ardor ceases.

107 ibid., Act II, iii. Masotto: Come along, move a bit closer. Contessa: Oh, no, I shall not be the first. M: Be good, my master. Count: I'd don't want to be the first either. 
Masotto displays a willingness and respectfulness that differentiates him completely from Lesbina of Il filosofo di campagna. Even without her imposing manners, however, he rises to a central role within the plot to facilitate many of the events. Also of note in his aria is the progression of action that it implies. The aria does not create a moment of stasis; rather, we understand that while Masotto is singing, not only does action occur but more importantly, emotions and dispositions are changing as a result. This dramatic strategy keeps a further distance from the declamatory style of traditional melodramma.

Only when harmony is restored do the Count and Countess regain their composure. As this occurs, their language changes dramatically:

CONTESSA. Perché confesso la debolezza mia, v'amo e figlia d'amore è gelosia.

Chi può nel nostro petto l'affetto regolar?

Io non lo posso no. E sempre v'amerò

penando ognora.

CONTE (solo). Per dir la verità,

la contessa è amorosa, compatirla convien s'ella è gelosa.

(...) non vuò più Guerra con la sposa mia.

Dolce amor che m'accendesti

delle nozze il dì primiero,

deh ritorna, nume arciero,

questo core a consolar.

La discordia i dì funesti

più non renda fra due sposi;

ed i spasimi cruciosi

non ci tornino a turbar. ${ }^{108}$

M: Just a little at a time. A little from each. I see there is some reluctance; with permission, sir, I think I'll go. Humble servant, very obsequious, whenever you call me, I will be ready, I'll come to serve. Step over that way (to one), turn that face this way (to the other). Ah, what amiable gladness, when two spouses love each other, to see a heart clouded by rage return to peace.

108 ibid., Act III, ii1 iii. Countess: Because I confess my weakness. I love you, and jealousy is the daughter of love. Who is able to command the affections of our own heart? I cannot, no. And I shall always love you, and always suffer. (...) Count: To tell the truth, the Countess is in love, and if she is jealous, it would be better to understand her pains. I no longer want war with my wife. Sweet love, who ignited 
Here in the final act, these aristocratic characters express themselves in true serio terms for the first time, regaining Metastasian turns of phrase ("penando ognora," "nume arciero") typical of opera seria. Overall, however (and notwithstanding a few classicizing exceptions), even within a melodramatic style Goldoni achieves balance, maintaining the language elevated but without stalling the action with digressive and generic metaphors, and Galuppi helps to keep it moving with a lilting minuet. On a psychological level, noteworthy is Goldoni's realistic use of veiled, non-explicit terms to create the tender sadness that permeates the Countess's wistful recitative and aria. The Count's aria too, in its plaintive invocation of Cupid's arrows, resounds almost as a prayer to the archaic god of love. In synthesis, these two characters journey from one stylistic boundary to the other over the course of the work, providing comedy and gravity at different times. Their transformative roles exemplify the way in which, through a realistic portrayal of his characters, Goldoni continues to erode the boundaries between traditional buffo and serio roles.

We witness this not only in the traditional serio parts, but also at times in characters of lower extraction, who manifest a broad spectrum of dramatic registers through the changing action. If at first the Count and Countess take on aspects of buffo in their quotidian language, rapid exchanges, and comic obstinacy, later we find the comic sense of these traditionally buffo figures is darkened by more serious language. Unlike the melancholy of Eugenia in Il filosofo di campagna, most of the serio material in Le nozze is prompted by rage, and notwithstanding their nearly insurmountable divisions, the Count and Countess are not the only characters to express themselves with intensity in this respect. Even a humble gardener (Mingone), when faced with rivalry, uses no uncertain terms:

...lo voglio sbudellare,

se fosse in mezzo alle più forti squadre,

se fosse ancora in braccio di sua madre.

me on our first day of marriage, oh return, arrowed god, to console this heart. Let discord no longer render the days of two lovers so baleful; and spams of distress never upset us again. 
Mi par di ridere con quel ragazzo,

lo voglio uccidere con le mie man.

Poi per il mondo da pellegrino

miglior destino cercando andrò. ${ }^{109}$

Choice words (e.g. "sbudellare") evidence that Goldoni deliberately preserves the comic element in this aria, unequivocally exposing Mingone's coarseness, Galuppi contributes with a propulsive and playful Allegro assai. The gardener's piece therefore would never be considered a serio aria. However, the length of the piece, its pivotal structural function as an exit aria, and most importantly the intensity of Goldoni's terms ("fosse anche in braccio di sua madre...lo voglio uccidere con le mie man"), all contribute a novel sense of gravity to the scene, casting a cloud over the underlying comic diversion.

The attenuation of rigid boundaries between roles continues in later operas such as Galuppi's La diavolessa (1755, given at the S. Samuele but set in Naples). Again, no explicit division of roles is made, yet implicitly the cast of characters is listed in descending order of prominence, from serio to buffo with many nuances in between. Textual analysis suggests the presence of two mezzi caratteri of different social standing, the gentleman Don Poppone (likely bourgeois, as his title is never made explicit), and the "avventuriera" Dorina, who abandons her family to marry her lover, Giannino. La diavolessa does not warrant a comprehensive analysis, but it does contribute a few elements of note, all connected to Goldoni's treatment of boundaries between the wellto-do and the plebeian. In this opera, our author returns to the familiar device of role exchange to undermine the foundations of class division. When Don Poppone mistakes Dorina for a noblewoman, for example, she transforms into one:

Eh, che l'amore più candido, più puro

vuole il suo chiaroscuro.

E poi convien distinguere

109 ibid., Act II, scene xii. I want to eviscerate him, even if he were protected by the strongest troops, or if he were still a baby in his mother's arms. I could almost laugh with that young man, I want to kill him with my own hands. Then, as a wanderer, I'll travel to world seeking better fortune. 
della plebe l'amor, come si sa,

da quello della nostra nobiltà.

Voglio che civilmente ci trattiamo.

O che siamo, cospetto! o che non siamo.

Si distingue dal nobile il vile anch'in questo, mio caro signor.

Una donna ch'è nata civile

non si lascia avvilir dall'amor. ${ }^{110}$

As seen in previous operas, Goldoni creates an external projection of social standing through the realistic imitation of mannerisms and language, and the reiteration of common ideas. He carries this technique to a level of parody a short while later, when Giannino too improvises the manners of a modern aristocrat:

Vo' provar con bassa gente;

e vo' far il prepotente.

"Insolente, non do niente...

Pagherò, quando vorrò.

Ne ho bisogno, via di qua."

Ah ah ah. (ridendo) Bene va.

L'ho trovata in verità. ${ }^{111}$

This jesting imitation is purely comic, but pricks at familiar contemporary themes of corruption and moral degradation. The likening of a nobleman to a "prepotente," together with allusions to disregard for debt and for the needs of others again connect this work to modernity and its vices. Notwithstanding the Neapolitan setting, this opera remains relevant to the Venetian audience through its social commentary and even

110 Carlo Goldoni, La diavolessa, Act I, vii. Oh, that even the most candid, the purest love desires its ups and downs. It would be better to distinguish the love of commoners from that of our nobility. I want us to deal with civility. Whether we be, or not. The noble will distinguish himself from the commoner in this too, my dear sir. A woman born noble does not let herself be disheartened by love.

111 ibid., Act I, ix. I want to try my hand with the common people, I want to act assertive. "Insolent, I'll give you nothing... I'll pay, when I want. I need that, get out of here." Ah ah ah (laughing), that's good. I've really found it. 
includes an aria in Venetian dialect (sung by Dorina, who has travelled the world).

More parody of serio elements, though of different nature, ensues in La cascina (The Farmstead, 1756) first set by Giuseppe Scolari (17201774). Rather than targeting the paradoxes of city life and modern profit, this bucolic, pastoral opera retreats once more to simple country life, in which pagan gods resurface to create a place away from time. Notably, however, classicizing references are exaggerated to such a degree that the Arcadian stamp of the work becomes jesting, not truthful. The character of Il Conte Ripoli, for instance, is a serio part in caricature; indeed he is called "l'affettato." Ripoli speaks in Arcadian metaphors but with none of the Arcadian gravity. The cascina (farmstead) is allegorized as Carthage, ladies crossed in love become Virgilian heroines ("ecco un'altra Didone abbandonata"), and constant references to Alceste, Demetrio, Celonice, and others saturate his recitative. When the Count takes up a rage aria, also full of Classical references and intense language, the exaggeration therein thwarts the gravity of a true serio piece, and the number is downgraded to an arietta, preceded and followed by the dialogue of others:

Furie del cieco Averno, mostri del nero abisso

orsi, tigri, leoni, della barbarità crudel deposito,

su, venite, vuò fare uno sproposito.

Dov'è quel moro infido?

Vuò svenarlo sugli occhi alla mia Dido. ${ }^{112}$

While signing this work under the name of "Polisseno Fegeio, pastor arcade," Goldoni does not hesitate to revisit the Classical world and the serio style in a satirical key, further distancing himself from the traditional treatment of these roles. His characterization of "l'affettato" in La cascina is another clear example of how our author progressively dismantles common practices in his libretti.

Goldoni's unconventional portrayal of traditionally serio characters returns markedly in Fischietti's La ritornata di Londra (The Returned

112 Carlo Goldoni, La Cascina, Act III, iv. Furies of the blind Hades, monsters of the black abyss, bears, tigers, lions, repositories of barbarous cruelty, up, come, I want to commit a crime. Where is that infamous moor? I want to slash his veins before the eyes of my Dido. 
from London, 1756), a peculiar work in which all of the characters are of noble extraction, as will recur in Il festino (The Banquet, 1777, written in Paris but set in Venice). The only figures of contrast in a panorama of Counts, Barons, and Marquis are Madama Petronilla, a virtuosic opera star, and her chambermaid. With many rivals for the attentions of Petronilla, the male characters cannot escape becoming the comic source of the work. Their forward, haughty mannerisms, and high-sounding circumlocutions go hand in hand with the vanity of each believing himself to be the favorite. The entangled relationships result in a good number of rage arie but create none of the gravity or tragic undertones of serio material. The entire opera, in a way, becomes a play between outward appearance and inner truth, in which elaborate formalities and ceremonious ritual expand to occupy the entire dramatic space. Introspection or pathetic elements are simply rendered obsolete by the frivolity that dominates.

La ritornata di Londra demonstrates once again that, in the realistic dramma giocoso, serio does not appear by definition but only when mandated by plot. Earlier works of Goldoni, if without figures of nobility, were also without parti serie. To this, we now must add that, even in the presence of aristocratic figures, serio is not guaranteed. By this point in Goldoni's experience with libretti, the author's distance from previous traditions is more and more consolidated; the distinction between serio and buffo is no longer dependent only on station, but, in a more realistic approach, is also regulated by conduct.

Furthermore, what La ritornata di Londra lacks in depth of characterization it gains in structure and ensemble pieces. These excel in invention and complexity, animating the triangular (and quadrangular) relationships between prima donna and suitors. Notably, Goldoni places an intricate ensemble as early as the second scene of the work, in which the Marquis and Baron each search for a pretext to remain alone with Petronilla, much to the chagrin of her secret lover, Carpofero. In an extended and dynamic scene, the men speak to Petronilla, to each other, and to the audience in asides, all in rapid alternation. The innovation resides in Goldoni's placement of such a developed ensemble well before the closure of the first act, yet after 
the opening of the work. Goldoni then replicates the scenario, with even more characters tied in, at the closure of each act.

Goldoni continued to create drammi giocosi for numerous Venetian theatres (San Samuele, S. Angelo, S. Moisè) even while his comedies were suffering the growing antagonism of opponents Carlo Gozzi and Pietro Chiari (they could not, however, dispute his primacy in musical theatre). By 1758, the challenges and hardships of the theatrical world in Venice had already brought him to consider moving elsewhere. In fact, during that year he was prompted to accept an invitation to collaborate with the Teatro di Tordinona in Rome, a first attempt to forge himself a different path. Though the author returned to Venice less than a year later, his experience in Rome laid the foundation for a more definitive departure in the future, as well as the groundwork for the continued circulation of his texts via correspondance. ${ }^{113}$

Before departing, Goldoni presented Il mercato di Malmantile (The Market of Malmantile), set by Fischietti (though possibly by Scarlatti as well, in a lost version) among other works at the Teatro S. Samuele. It is his first text for music in which the protagonists (the governatore Lampridio and his daughter Brigida) are members of the borghesia. In fact, the mercantile world of middle-class commerce constitutes the broader universe of the work, as the title suggests. The shared space of the marketplace piazza, in which all buy and sell, functions as an element of cohesion between characters of varying social extraction. While buffo and serio characters are not explicitly divided, this opera is also noteworthy for its treatment of serio material, moderated in a realistic key. When Brigida, desirous of ascending the social ladder, sets her sights on the Conte della Rocca, his lover, the widowed Marchesa Giacinta expresses her grief in a short aria:

Ah purtroppo m'inganna il traditore.

Non vi è costanza al mondo, non vi è più fedeltà.

Misera mi confondo, tutto penar mi fa.

Ma se il crudel ritrovo

lo sdegno mio saprà.

113 See Pier Mario Vescovo, "Goldoni: vacanze romane" in Settecento romano. Reti del classicismo arcadico (Rome: Vilella, 2017). 
O l'amor suo rinova

$\mathrm{o}$ il fio mi pagherà.(parte) ${ }^{114}$

This piece, which in some measure resonates with Donna Elvira's debut aria ("Ah, chi mi dice mai") in Mozart and Da Ponte's later Don Giovanni, is measured in tone, and does not use the generic language or poetic hyperbole of the traditional melodramatic style. Instead, it is realistic in its moderation, also thanks to the psychological progression it contains. In the span of hardly two strophes, Goldoni changes the emotional content from grief to rage, lending the action a sense of propulsion, not static reflection. Fischietti develops this piece at length, traveling between virtuosity (coloratura passages, dotted rhythms) and expressiveness (chromaticism, appoggiature, etc.). As a further realistic and forward-looking element, Goldoni makes clear that Brigida's attractiveness is not solely the result of her uncommon beauty, but rather the merit of her intelligence: "Il suo vanto fu sempre il saper." The idea of interior beauty is in fact pursued quite explicitly (though to some comic effect), here expounded upon by the governatore her father (Lampridio), and the buffo Rubicone:

RUBICONE. Si conosce, si vede, si sa

di quel volto la rara beltà

ma del bello si apprezza ancor più

la famosa stupenda virtù.

LAMPRIDIO. Ma del bello si apprezza ancor più

la famosa stupenda virtù.

BRIGIDA. Quel ch'io sono, signore, lo so

ma di questo vantarmi non vuò.

Non è facil trovar oggidì

una donna che parli così. ${ }^{115}$

114 Carlo Goldoni, Il Mercato di Malmantile. Act I, x. Alas, sadly the traitor is deceiving me. There is no constancy in this world, fidelity is no more. I am wretched and confused, everything makes me suffer. But if I find the cruel traitor, he will know my anger. Either he renews his love to me, or he will pay me retribution.

115 ibid., Act I, xii (ensemble finale) Rubicone: We recognize, we see, we know the rare beauty of that face, but even more than beauty, we esteem famous, stupendous virtue. Lampridio: Even more than beauty, we esteem famous, stupendous virtue. Brigida: I know what I am, sir, but I don't want to brag about it. It's not easy these days to find a woman who can speak like this. 
While Brigida's false modesty is derisible and calls her "stupenda virtù" into question, the conversation does reflect a changing ideal and seals its closeness to modernity and to the real world with "oggidi" (nowadays). Nor is Brigida the only character in the comedy to seek social change; the doctor Rubicone also wishes to improve his condition in marrying her, and Lena the contadina, a secondary buffo, also tries to enter society by securing the governor Lampridio. The contrast between aspiration and reality becomes an excellent source of comedy, as Rubicone asserts, "Di nobiltade in casa mia si sguazza. (Son tutti i miei feudi un banco in piazza)." 116 In the end, however, all are paired with their 'equals': the Marchesa with the Count, Lena with Berto, another farmer, and Brigida with the charlatan doctor Rubicone.

Similar strategies for realism, and analogous moderation of tragic and comic extremes, can be found in La conversazione (The Conversation) of the same year (1758), set by Scolari, in which we easily discern parti serie, parti buffe, and mezzi caratteri. The space between buffo and serio is occupied by a borghese who has traveled the world (Giacinto), and a nobleman reduced to poverty (Don Fabio). The first is noteworthy for the changeability of his character:

In quattordici lingue parlo, scrivo, e traduco.

So i riti, so i costumi dei popoli remoti

e gl'incogniti ancora a me son noti.

Coi vili son asiatico (fa il grave)

coi grandi sono italico (fa l'umile)

Nel spender sono inglese.

Son colle dame un paladin francese (fa riverenze e parte). ${ }^{117}$

Giacinto is not a nobleman, but his knowledge of the world gives him extra assets and contributes to his appeal in society. More importantly, thanks to his travels, he is able to stay connected to the latest trends:

116 ibid., Act III, vii. At my house, we are dripping with nobility. (All my holdings are a stand at the market).

117 Carlo Goldoni, La Conversazione, Act I, i. I can speak, write, and translate in fourteen languages. I know the customs and rituals of the most distant peoples, and I know what is unknown. With the lowly, I am Asian (with gravity), with the powerful, I am Italian (with humility). In expenses, I am English. With the ladies, I am a French paladin (bows and exits). 
"Questo, signora mia, splin si chiama in inglese, che in Italia vuol dir malinconia." 118 Splin (spleen) of which we read even in Shakespeare, is especially relevant and in vogue as a poetic concept beginning in the 18th century. Goldoni's reference to it connects the opera closely to the contemporary world and its fashions. What is more, the particular emphasis brought upon melancholy and the nostalgic humors represents Goldoni's direct acknowledgement of new tendencies that have slowly become part of his theatre. Serio appears no longer as a mere question of Metastasian style, but now is more intimately connected to sadness or melancholy. This same new trend contributes to the increasing production of novels, and in theatre leads to new hybrid genres such as the French comédie larmoyante, defined by P. Larthomas as "(...)genre intermédiaire entre la comédie et la tragédie, qui introduit des gens de condition privée, vertueux ou presque, dans une action sérieuse, grave, parfois pathétique, qui nous excite à la vertu en attendrissant sur ses infortunes et en nous faisant applaudir son triomphe." ${ }^{119}$ Goldoni thus connects himself to a contemporary literary trend through which he can also create greater realism.

In the character of Giacinto, Goldoni looks ahead to modernity. By contrast, his Don Fabio, an impoverished nobleman, represents the shadow of a past regime fading into oblivion. Yet, while his desire remains that of acting as a gallant protector of ladies in need, he too has been led to accept new, enlightened perspectives: "Non stimo l'esser bella, stimo la cognizione di distinguere il merto e le persone." 120 The character of Don Fabio is balanced by a foil, Sandrino, of common origins but extremely wealthy. The opposite social and financial situations

118 ibid., Act I, vii. This, my lady, is called spleen in English, which in Italy means melancholy.

119 P. Larthomas, cited in A. M. Finetto, "La Pamela e La Buona Figliuola: Il Linguaggio Patetico di Goldoni”, in Studi Goldoniani quaderno 8 (Venezia: Casa di Goldoni e Istituto di Studi Teatrali dei Musei Civici Veneziani, 1988); 107. (...) an intermediary genre between comedy and tragedy, that introduces ordinary people, virtuous or almost, into serious, grave, and at times pathetic circumstances, exciting us to virtue in moving us by their misfortunes, and leading us to applaud their triumph.

120 Carlo Goldoni, La conversazione, Act I, i. I don't value beauty, I rather treasure the capacity to distinguish merit and people. 
of the two men earn them the nicknames "Il Conte del Fumo" (the Count of Smoke) and "l'Asino d'Oro" (the Golden Ass), and the contrast between them affords ample comedy.

As concerns serio material, however, Goldoni yet again demonstrates a new, moderated approach that trades a recondite poetic language for realistic tones of greater immediacy. A love aria sung by Don Filiberto, a full serio character of noble birth and of good standing, exemplifies Goldoni's by now affirmed new style:

Via resterò per compiacermi ancora.

Troppo questo mio cuor v'ama e v'adora.

Lo so che il sospetto

fa torto al mio bene

ma soffro nel petto

gli affanni, le pene

di un timido amor.

Conosco l'error,

confesso l'inganno;

Me stesso condanno.

Ma palpito ancora. (parte) ${ }^{121}$

The lightness and simplicity of this piece could hardly have been conceivable in the traditional melodramatic style. It is thus clear that Goldoni has left the preceding tradition entirely behind, and in the name of realistic portrayal, is accomplishing a gradual attenuation of the rigid divisions between buffo and serio roles, his works not seeking pure comedy but rather a balanced representation of modern life and styles. As a final note, La conversazione, true to its title, is also an exercise in linguistic variety. This type of realism, unlike the personal reflections of Don Filiberto, is used instead to enhance buffo roles. While a noblewoman (Lindora) sings an arietta in Venetian dialect, Lucrezia the servant girl offers another in Bolognese, and others follow in a parade

121 ibid., Act II, ii. Alright I'll remain, to appease you once more. My heart loves and adores you too much. I know that suspicion is an injustice to my beloved, but I suffer in my breast the anxieties and the torments of a timid love. I know my mistake, I confess I was wrong; I condemn myself. And yet, my heart beats still. (exits) 
of linguistic sketches from all parts of Italy. Research is continuing to locate the surviving manuscript copies the musical score, which, like many of the operas on Goldoni's texts, has yet to be performed for modern times. Given the linguistic variety of the text, is it not unlikely that the music, too, could contain some allusions to popular traditions, especially when, later in the work, Goldoni inserts a Calabrian aria that denotes strong affinities to the llengua napolitana native to the original commedia per musica (note also the typical melancholic tone):

La notte quanno dormo penzu tanto

e quanno penso a buie mm'adormento.

Po me resveglio co no core schianto,

vado ppe tte parlare e non te siento. ${ }^{122}$

The linguistic virtuosity of La conversazione perhaps brings to mind the observations of Franco Fido, who once affirmed "nei suoi [di Goldoni] libretti quello che la parola infeudata alla musica perdeva sul versante del referente- cioè in termini di capacità di evocare con efficacia mimetica e critica il mondo reale: mercanti, donne di casa, servitori, ecc.essa guadagnava dalla parte del significante- scherzi e giochi di parole, paradossi e calembours, onomatopee e iperboli, equivoci e cacofonie plurilingui." ${ }^{23}$ Goldoni's inclusion of regional dialects is quite removed, however, from the "cacofonie plurilingui" here described. Rather, a textual approach demonstrates that, within an opera whose central theme is travel and exploration, linguistic variety instead directly supports the very "efficacia mimetica" that Goldoni was thought to lack.

In a long list of successful drammi giocosi, only three more will be considered within the limits of the present chapter. The first to follow $L a$ conversazione is La fiera di Sinigaglia (The Fair of Sinigaglia, 1760), again by Fischietti, a special commission by the Teatro delle Dame in

122 ibid., Act III, iv. At night, when I sleep, I think a lot, and when I think in the dark I fall asleep. Then I awake with my heart in pieces, I go to speak to you, and yet hear nothing.

123 Franco Fido, "Riforma e controriforma del teatro. I libretti per musica di Goldoni fra il 1748 e il 1753 in Studi Goldoniani, vol. 7 (Venezia: Venezia: Casa di Goldoni e Istituto di Studi Teatrali dei Musei Civici Veneziani, 1985); 65. [previously translated] 
Rome. Goldoni's presentation of the work outside the familiar context of his own Venetian audiences by no means tempers his critical agenda. In fact, La fiera di Sinigaglia features two aristocrats in full decline, the Conte Ernesto and Lisaura, "nobile discaduta." Il Conte Ernesto displays gentlemanly composure with evident affectation and expresses himself in the language of a parte seria:

\author{
Se si desta al rumor delle schiere \\ stringe il ferro il guerriero più ardito; \\ e all'invito dell'armi già parmi \\ che feroce sen corra a pugnar. \\ Io non sono mia bella così. \\ Perché' ho il cor di pietade ripieno \\ e vien meno se chiedigli aita \\ la bellezza che sa lagrimar. ${ }^{124}$
}

Notwithstanding, he has long-running debts with every vendor in the market of Sinigaglia. His aristocratic self-image compels his to take the "discaduta" Lisaura under his protection, yet he must bend over backwards to assure her a living, for, as his middleman Griffo explains, "è un protettore senza monete, di quei che si usano ai nostri dì." ${ }^{25}$ While a destitute nobleman at this stage of Goldoni's production is no longer a surprise, an absolute novelty of this work is the appearance of a borghese just as ill-equipped. Orazio, a merchant of Sinigaglia, is, much like the Count, drowning in debt. Ted Emery, who deemed Goldoni "the bard of the bourgeoisie," has seen what he terms "ideological fragility" in the author's less adulatory representation of exponents the middle class (though he does not analyze La fiera di Sinigaglia explicitly). Emery concludes that, in targeting the middle class once emblematic of his 'reform' comedies, the author abandons his efforts for realism and commences an inverse process (what Franco Fido called "counter-reform," an interpretation now widely surpassed). ${ }^{126}$ Textual analysis

124 Carlo Goldoni, La Fiera di Sinigaglia, Act I, i. If he awakes to the noise of troops, the bravest warrior will grasp his sword, and at the call to arms, I can already see him, fierce, running towards combat. I, my beauty, am not like that. Because my heart is full of tenderness, and it nearly faints if a tearful beauty asks for help.

125 ibid., Act I, ii. He's a penniless protector, one of those in vogue nowadays.

126 Ted Emery, Goldoni as Librettist; 77. 
reveals a different reality. If the working-class, in social ascension for decades, now also begins to feel the pricks of corruption as the result of past affluence, Goldoni's indication of this new societal risk can only be understood as a courageous step towards even greater realism and objectivity, not a change in belief. In concrete terms, this translates to the use of a rich lexicon of technical terms from the world of commerce, including denari, ipoteche, creditori, cambiali (cash, mortgages, creditors, promissory notes), etc. In the same way, rather than "ideological fragility," the author's newly targeted critique demonstrates a willingness to confront even the most paradoxical of problems, and reiterates his implicit belief in the moral utility of comedy. Orazio, like the Count, pretends to be who he is not, boasting economic success. Once more, the pragmatic Griffo checks his imbalance with truth "Superbia e povertà stan male insieme,"127 and eventually Orazio admits his own responsibilities, "per far di più di quello che comportava il mio stato, da me stesso mi son precipitato." 128

Ultimately, poverty neutralizes disparities of rank:

ORAZIO. Son servitor di lei la venero e la stimo; ma se non ha denari, signor conte padron, noi siam del pari.

Cosa val la nobiltà senza il lustro del contante?

Il signore ed il mercante non si stima, se non ha.

Non ho il capo cincinnato, non vo' liscio ne staccato

ma mi faccio rispettar, se la quaglia fo cantar.

Mi fanno ridere questi zerbini, senza quattrini,

quando pretendono farsi stimar.

Non se n'avvedono, si fan burlar. ${ }^{129}$

127 Carlo Goldoni, La Fiera di Sinigaglia, Act I, vi. Pride and poverty don't go well together.

128 ibid., Act II, vi. In seeking to move beyond my state, I brought about my own downfall.

129 ibid., Act II, vi. I am your humble servant, and respect and esteem you; yet, if you have no money, then, sir Count and Lord, we are equals. Of what value is nobility without the sparkle of gold? Neither the lord nor the merchant are esteemed if they lack it. I'm not a Cincinnatus [statesman and Roman consul], I don't go about smoothly, nor aloof, but I too can make others respect me, if I tell what I know. They make me laugh, these doormats without a dime, when they have the pretention of being esteemed. They don't realize they expose themselves to ridicule. 
Other contemporary figures, both male and female, also offer timely critique. Griffo, a practical and prudent proto-Figaro, becomes the voice of truth. With direct language, he reveals the true state of the more changeable characters, including the Count, Orazio, and the trinket-seller Prospero, who lends money at high rates of interest: "costui che finge l'uom dabben." ${ }^{130}$ With realism and practicality, Griffo explains his trade in the following terms:

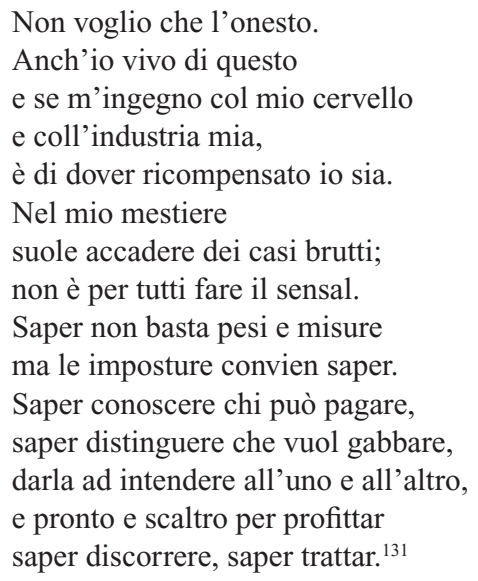

The direct language and short phrases here employed, along with the Fischietti's musical setting, clearly designate this aria as a buffo piece, though its comic effect is sensibly outweighed by its practical bent. The illustration of the struggles and deceits encountered in daily life connect this piece so completely to the real world that it would appear (if not for the musical rhythm), almost drawn out of a prose comedy. Griffo evokes a world governed by commerce, in which every sort of man tries to draw

130 ibid., Act I, vi. (...) he who pretends to be an upright man.

131 ibid., Act II, v. I want nothing except what is honest. This is my living too and if I set my mind to it, and apply my wit and my hard work, it's only fair that I should be rewarded. In my trade/ unpleasant cases/ often arise; being a broker/ is not for everyone./ It's not enough/ to know weights and measures/ but one must know/ impostures too./ Know how to tell/ who can make payment/ and to distinguish/ who wants to cheat/ and drop hints/ to one and the other/ and quick and ready/ to make a profit/ know how to converse/ and how to negotiate. 
his own profit. Again, we note the insistence on wit and readiness as one's best assets, indispensable for survival in an increasingly complex world of simulation and deceit.

Griffo's good sense is known by women as well. In particular, we find his feminine counterpart in Giacinta, a locandiera not without the perspicacity of Goldoni's heroine Mirandolina (from the widely famous La locandiera, prose comedy of 1753). Giacinta, who earns her profit through honest labor, also speaks with candor and denounces the vanity of both the borghese Orazio, who aspires to gentlemanly state while greatly indebted, and of Lisaura, the noblewoman who has dissipated her holdings so completely as to be reduced to panhandling (but not any wiser for it) and entirely dependent on the generosity (or pomposity) of any protettore she can find. Unlike Griffo, who speaks in asides or alone, Giacinta does not shy from direct confrontation:

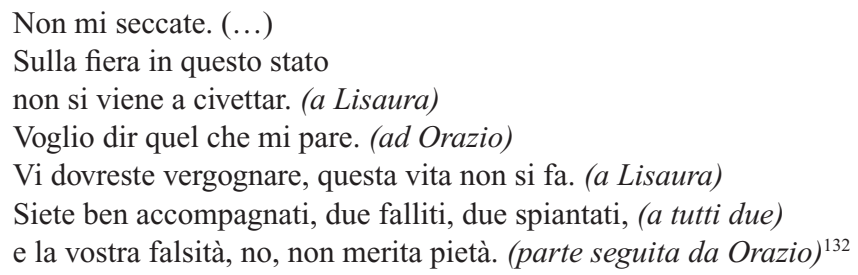

In conclusion, La fiera di Sinigaglia is a markedly modern work both in realistic style and content, which offers a continual critique of contemporary and widespread social issues. The ancient class divisions appear by this point completely dismantled, and Goldoni's portrayal of corruption and vanity within the borghesia signals a new phase in his society and in his theatre. Much like Il mercato di Malmantile, the very setting of La fiera di Sinigaglia, anchored within the world of commerce, provides a fertile shared space for the manifestation of a large array of social types. The truthfulness and intelligence of those who are honest in their trade, thrown into direct comparison with those who,

132 ibid., Act II, xiii. Don't bother me. You shouldn't be flirting like this at the market (to Lisaura). I want to tell you what I really think (to Orazio). You should be ashamed of yourself, this is no life to live (to Lisaura). You go very well together, two failures, and penniless (to both), and your falsehood, no, it merits no pity. 
as Goldoni writes “...non se n'avvedono, si fan burlar” (don’t realize that they expose themselves to ridicule) allows for new, forward-looking ideals of integrity and social equality to surface, all the while taking Goldoni's realist agenda to a higher level of efficacy.

The above-cited operas also exemplify how the artisanal world, since the 1750-51 season a central element of Goldoni's prose comedies, appears with increasing frequency in Goldoni's drammi giocosi. The realism inherent to this subject matter prompts Goldoni to revisit the merchant world in L'amore artigiano (Artisan Love, 1761, score by Gaetano Latilla), part of a trilogy with L'amor contadino (Country Love, 1760, score by Giovanni Battista Lampugnani in which again the simplicity of rural life is praised as an antidote to moral corruption) and L'amore in caricatura (Love in Caricature, 1761, score by Vincenzo Ciampi, another attack on the ceremonial, superficial pretenses of aristocratic protagonists). L'amore artigiano too revolves around a shared common space or piazza, in which different botteghe or ateliers are shown open and working concurrently:

Piazzetta come nelle scene antecedenti, colle botteghe aperte del fabro e del calzolaio e di più in mezzo la bottega aperta di legnaiuolo col banco fuori e varie tavole ed instrumenti di cotal arte. Fuori della bottega del fabro una picciola incudine e fuori di quella del calzolaio una pietra, su cui tali artisti sogliono battere il cuoio; di qua e di là le case come prima. ${ }^{133}$

Perhaps it is no coincidence that this same realistic strategy, using a shared work space that permits the interaction of many, will be used by Goldoni for the signature opening of Le baruffe chiozzotte (The Quarrels in Chioggia, 1762), a famous prose comedy written just a few years later.

The opera furthermore contains an arietta in Venetian dialect (Act II), and furthers Goldoni's newly moderated, disenchanted approach

133 Carlo Goldoni, L'Amore artigiano, Act I, xvii. Small piazza as in the previous scenes, with the smith and the cobbler shops open, and in addition the carpenter's house between them, with a working table outside and various other tables with instruments of such trade. Outside the smith's shop, a small anvil, and outside of the cobblers, a stone, on which these artists beat and soften the leather; here and there houses as before. 
to the characterization of both serio and buffo roles. The artisans are humble people who serve the resident nobility, yet enter into discourse with the higher class in a new and direct manner, claiming the rights and dignity of their work over the capricious pretenses of their patrons. Rosina, a seamstress, speaks to a noblewoman in terms that hitherto would have been inconceivable:

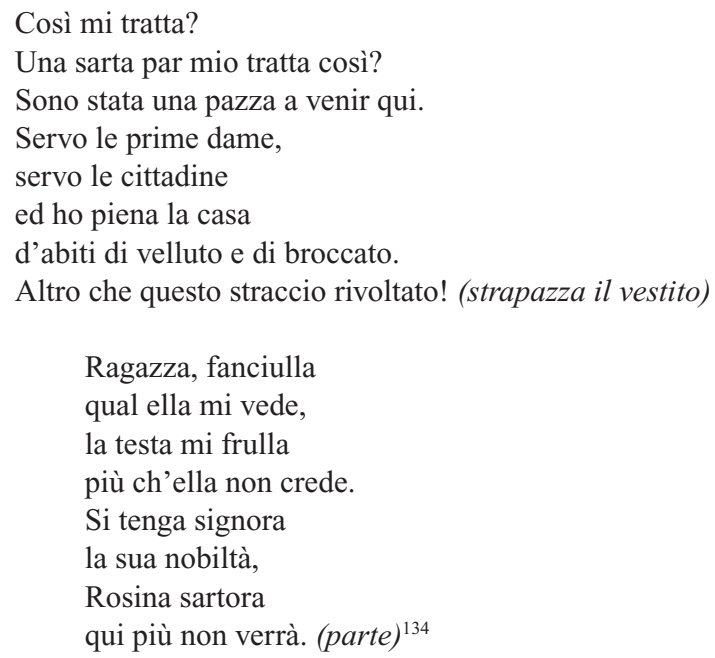

At the same time, part of this working class is by no means immune to fallacy, as Goldoni also includes characters who suffer from the familiar temptation of wine and gambling and who behave with presumption. In a scene unlike any other in opera, newlyweds Rosina and Giannino, after a long, trying odyssey towards marriage and much poetic courtship, begin to vehemently argue over expenses as soon as they are pronounced man and wife, partially calling into question the traditional lieto fine. A secondary surprise in this regard is the elegant

134 ibid., Act I, xiv. This is how you treat me? A seamstress of my caliber you treat like this? I was mad to come here. I serve the first ladies, and all the noblewomen, and my house is full of velvet and brocade gowns. Far from these pitiful rags! (she crumples the gown) (...) Maybe you see me as just a young girl, but my head is working more than you know. Keep your nobility, Madam, Rosina the seamstress will never come here again. (exits) 
serio language used by Giannino, a carpenter (note the archaic allusions to death and to the burning of love):

Non posso riposar, non trovo loco,
cerco qualche ristoro alla frescura.
Ma dove i' vado porto meco il foco
ed è il mantice mio fra quelle mura.
(...)
Oh s'io potessi rinfrescarmi un poco
non morirei dall'amorosa arsura,
amore il tuo Giannin si raccomanda,
fagli vedere il sol da questa banda. ${ }^{135}$

These lines are almost indistinguishable from those uttered by the true parte seria, Fabrizio. Again, Goldoni demonstrates that the distinction between serio and buffo has now moved beyond simple distinctions of class (ever more called into question), and has come to hinge instead upon the interior equilibrium and quality of conduct of the individual.

Finally, we come to the last noteworthy opera of Goldoni's Venetian years, the peculiar La donna di governo (The Governess, 1761, premiered in Rome, at the Teatro Argentina). Corallina, the donna di governo is labeled as a parte buffa, though her condition is hardly laughable. She is bound to a lover (Ridolfo) who spends his money and hers on the gambling table, and, unaccustomed to working, harbors other vices too: "Ha il giochetto e l'osteria, va la notte in compagnia,"136 etc. Corallina is blind to his true nature, yet with the same lies and deceptions takes advantage of the elderly and wealthy Fabrizio. Fabrizio, for his foolishness, is also listed as a parte buffa, while his virtuous niece is instead a seria, though they share the same social condition. From Fabrizio, Corallina obtains gifts and attentions, but not yet satisfied

135 ibid, Act I, i. I cannot rest, I find no place, I search in vain for cool relief. Instead, wherever I go I bring with me the burning fire, and my bellows are behind those walls. (...) Oh, if only I could find refreshment, I would not die from the burning of love, love, Giannino entrusts himself to you, let him see the sun [the face of his beloved] before him.

136 Carlo Goldoni, La Donna di Governo, Act I, iii. He's got gambling, and the pubs, and spends the night in company... 
also steals from his cellar, thereby providing for her lover Ridolfo, her widowed sister Lindora, and Moschino, a servant and accomplice. La donna di governo thus features a negative heroine, who creates grief for the parti serie yet remains unpunished thanks to the protection procured by her arts.

Attention to profit permeates the work. It is manifest in the actions of almost every character, and dispositions change in relation to circumstance, not to any moral compass. Even Lindora, who at first tries in good faith to alert her sister to Ridolfo's true nature, in little time transforms thanks to the promise of payment in exchange for her silence. Goldoni thereby creates a desolate panorama of superficiality and moral emptiness in which each maneuvers the affections of others to his own gain, such that even his social critique appears flattened by saturation.

Amidst the monotony of such corruption, some relief and stylistic variety is provided by the parti serie, who in this work display renewed adherence to their rightful moral foundation. Interestingly, it is not made explicit whether the serio characters have any claim to aristocratic heritage. All we know is that Rosalba's uncle is a benestante (a wealthy man). This, together with the fact that they are never addressed nor announced by any title within the work, would instead suggest their pertaining to the borghesia and not to the nobility.

This serio pair is the final tile in Goldoni's vast mosaic of social types. Having idealized and criticized commoners, nobles, and borghesi alike, Goldoni now assigns serio content to figures of realistic moral, social, and financial condition, and does this in the measure not of verses or single pieces as before, but over the entirety of their roles. The consistent characterization and reliable behavior of the parti serie is in fact even more exalted in its contrast to the changeability and inconstancy demonstrated by the others. On the textual level, the most noteworthy characteristic of these parti serie is the inclusion of elements of larmoyant and a penchant towards sentimentalism, present in the arie of both Rosalba and Fulgenzio her lover. To cite just one example, the following aria by Rosalba evokes true sympathy:

Sconsolata quest'alma dolente

solitaria fra taciti orrori

va spiegando coll'erbe e coi fiori 
quell'affanno che strugge il mio cor.

Fuggo l'odioso aspetto

dell'ingrata famiglia.

Ogniun m'insulta,

mi tradisce ciascun.

Il zio medesmo

frutto del vile inganno

mio nemico si è reso e mio tiranno. ${ }^{137}$

This serio piece combines elements of tragedy and despair with the dignity of a virtuous woman, and the bitter awareness of being the victim of deceit. It is a delicately balanced example of the new brand of serio that Goldoni has established through the course of his production, a style realistically moderated in tone and enhanced in its psychological immediacy.

Looking back over the production of his Venetian drammi giocosi, it is clear that Goldoni's mature style as manifest in Rosalba's aria has traveled a great distance from the Metastasian serio of La scuola moderna. At the end of more than a decade's work, he is able to create a nuanced, intimate illustration of emotional complexity hardly conceivable fifteen years earlier, the product of a lengthy and gradual process of creative experimentation. The attenuated contrast between buffo and serio, the new, realistic qualities of both dramatic types, and their synthesis in the mezzo carattere, have now matured in the dramma giocoso into the foundation of a decidedly modern and newly relevant opera theatre.

137 ibid., Act III, i. Desolate, my sorrowful soul, solitary amongst tacit horrors, can confide to the meadows and flowers the torment that consumes my heart. I wish to flee the odious image of my ungrateful family. Each insults me, all betray me. My uncle himself, as a result of the vile deception, now has become my enemy, my tyrant. 
Pervinca Rista - 978-3-0343-3564-5

Downloaded from PubFactory at 01/11/2019 02:35:03AM

via free access 


\section{How comedy changed opera}

Having witnessed the evolution of Goldoni's texts for music within the opera theatre tradition, the final, most important element that confirms the novelty and innovation of his drammi giocosi resides in the direct connections between the libretti and his groundbreaking works of prose comedy. Common ground in comedies and libretti can be found in both content and style. Thematically, affinity between libretti and comedies is widely apparent in the character types, situations, and social mores exposed in both. As early as 1748, the same year as La scuola moderna, Goldoni's prose theatre is already occupied with contemporary custom in the extraordinarily famous La putta onorata (followed by the sequel, La buona moglie), which also displays precocious elements of larmoyant. Only a short while later, we find hallmark original characters in works such as L'avventuriero onorato (The Honored Adventurer, 1751), a partially autobiographical comedy that presents a false lawyer and a failed merchant, and La moglie saggia (The Wise Wife, 1752), an unicum even for Goldoni, in which the heroine Rosaura, a virtuous wife betrayed by her husband Ottavio (naturally, Medebach) pays an unprecedented visit to her rival (the Marchesa Beatrice) to ask advice on how to win him back. ${ }^{138}$ Other works of similarly complex characterization include La figlia obbediente, (The Obedient Daughter, 1752), and Gli innamorati (The Beloveds, 1759).

I mercatanti (The Merchants, 1753, originally I due Pantaloni, though masks and dialect were eliminated when Goldoni sent the work to print) launches a positive image of the merchant class and targets familiar themes of prodigality and dissipation, as Pantalone, on the edge of ruin thanks to his son's unchecked spending, is saved by a merchant from Holland. Il festino (1754) attacks another relevant phenomenon, cicisbeismo, and so too does La sposa sagace (The Sagacious Bride, 1758), set in Palermo. Curiously, this work presents a female

138 Carlo Goldoni, La Moglie Saggia, see in particular Act II, vii. 
character, Petronilla, homonymous to the protagonist of the libretto $L a$ ritornata da Londra. The two women not only share their name, but moreover their circumstances and character traits: both are surrounded by cicisbei, and both seek and enjoy their attentions. There is no textual evidence to suggest a direct adaptation from one work to the other in this case, but similarities are such that a common inspiration for both characters was clearly present.

Naturally, we cannot forget the elevated realism of Goldoni's comedies in Venetian dialect, including Le donne de casa soa (The Women of Their Own Home, 1755, given at the Teatro S. Luca), Il campiello (The Venetian Piazza, 1756), and the later Le baruffe chiozzote (1762). The first two in particular, which present the popular life of Goldoni's city in a genuine, quotidian style, met with overwhelming success, and not only in Venice despite their strong dialectal ties. The higher echelons of Venetian society are instead central to Le morbinose (The Spirited Girls, 1758).

Speaking of Goldoni's most famous accomplishments in the direction of realistic theatre, however, we should not overlook the fact that the author's process in prose theatre, much like for his libretti, does not always follow a comfortable linear trajectory. In particular, just as Goldoni often but not always illustrates modernity or contemporary life in his libretti, some of his comedies, or the styles employed in them, also take steps away from the current reality. His mature production includes works such as Terenzio (1754) and Torquato Tasso (1755), for example, attempts in the field of historical comedy. In these works, Goldoni abandoned his own preferences in the effort to emulate a different style very much in vogue, and thereby equal or overturn the great success of Pietro Chiari, who specialized in this type of theatre.

Other comedies parody or draw from the generic imagery of older comic currents (e.g. La pupilla (The Pupil, 1757), Il padre per amore (The Father for Love, 1757)), and most importantly, become grounds for linguistic experimentation. In fact, a surprising number of Goldoni's comedies are not written in the realistic prose he is best remembered for, but in versi martelliani (Alexandrian verse) and endecasyllable. La scuola di ballo (The Dance School, 1759) is even a rare excursion in difficult terzine (tercets), an effort to gain back audiences after Goldoni's period of absence in Rome (which however 
did not meet with much success). We also find a singular return of the Commedia dell'Arte masks in a very late comedy, Il buon compatriotto (The Good Compatriot, 1762), written just before the author's departure for Paris. Goldoni's theatre once in Paris will also more consistently slip back towards the Commedia dell'Arte, still sought by Parisian audiences, but for specific reasons concerning his appointment at the Comédie Italienne.

Ultimately, the variation of content and language in his prose comedies testifies that, much like his libretti, Goldoni's 'principal' theatre too does not always follow a clean line of progress in the direction of the reform agenda. Rather, it is subject to experimentation and, in some cases, external stylistic demands. Goldoni's deviations or 'experiments' do not however undermine the success or integrity of his larger project, but are instead an important aid to understanding the multifaceted nature of a corpus often considered homogeneous.

\section{i. The musical elements of comedy}

Beyond linguistic experimentation, a more significant point of contact between comedies and drammi giocosi resides in Goldoni's improvements of structure in both theatrical genres. In opera, this is particularly manifest in the expanded use and complexity of ensembles, as we have seen. While the layering of independent voices is by nature a musical technique, notably, elements of textual polyphony also become noticeably present in Goldoni's mature prose comedy, and moreover acquire increasing prominence.

His Venetian masterpiece I rusteghi (1760) is an exemplary end result in this respect. This comedy in dialect boasts the particularity of featuring four protagonists, all of similar character and belief, yet each clearly individual; not an easy task, as Goldoni reminds us:

Si scorge dal titolo della Commedia non essere un solo il Protagonista, ma varii insieme, e in fatti sono eglino quattro, tutti dello stesso carattere, ma con varie 
tinte delineati, cosa per dire il vero dificilissima, sembrando che più caratteri eguali in una stessa Commedia possano più annoiare che dilettare. ${ }^{139}$

The four rusteghi most often appear together, creating symmetry of discourse in a polyphonic style. To the quartet of protagonists Goldoni also adds the coalition of their respective spouses, who counterweigh their husbands' strictness and conservatism ("El xè un orso, fia mia; nol se diverte élo, e nol vol che se divertimo gnanca nu" ${ }^{140}$ ) with liveliness and adesire to experience the world ("Via donca, che el ne mena un pocheto in maschera"141). The interactions of the two quartets create multiple levels of symmetry, not only within each group but moreover between them, as the conservative men and progressive women challenge each other in a battle of the sexes.

Midway through the first act, Goldoni creates a duet that reveals more than a few affinities with the choral quality of his drammi giocosi, a musical progression carried through the entire scene (therefore a larger excerpt is required):

LUNARDO. Gh'aveu dito, che el volè maridar?

MAURIZIO. Ghe l'ho dito.

LUNARDO. Cossa dìselo?

MAURIZIO. El dise, che el xè contento, ma el gh'averave gusto de véderla.

LUNARDO. Sior no, questi no xè i nostri pati. (con isdegno)

MAURIZIO. Via, via, no andè in colera, che el puto farà tuto quelo che voggio mi.

LUNARDO. Co volè, vegnimo a dir el merito, la dota xè parecchiada. (...)

MAURIZIO. No stè a spender in abiti, che no voggio.

LUNARDO. Mi ve la dago, come che la xè.

MAURIZIO. Gh'àla roba de séa?

LUNARDO. La gh'ha qualche strazzeto.

139 Carlo Goldoni, I Rusteghi, "The Author to his Readers." From the title you will see that the Comedy does not have one single protagonist, but different ones together, and in fact they are four, all of the same character, but delineated in a variety of tones, something to tell the truth very difficult to do, because it seems that multiple similar characters in a Comedy would appear to be boresome, rather than entertaining.

140 ibid., Act I, i. He's a bear, my child. He never enjoys himself, and he's determined that we shouldn't either.

141 ibid., Act I, i. Come, take us out in costume for a bit. 
MAURIZIO. In casa mia no voggio séa. Fin che son vivo mi, l'ha da andar co la vesta de lana, e no vòi né tabarini, né scuffie, né cerchi, né toppè, né cartoline sul fronte.

LUNARDO. Bravo, sieu benedeto. Cusì me piase anca mi. (...)

LUNARDO. Ghe xè pochi, che pensa come che pensemo nu.

MAURIZIO. E ghe xè pochi, che gh'abbia dei bezzi, come che gh'avemo nu.

LUNARDO. I dise mo, che nu no savemo gòder.

MAURIZIO. Poverazzi! ghe vèdeli drento del nostro cuor? Crédeli, che no ghe sia altro mondo, che quelo, che i gode lori? Oh compare, el xè un bel gusto el poder dir: gh'ho el mio bisogno, no me manca gnente, e in t'una ocorenza posso meter le man su cento zecchini!

LUNARDO. Sior sì, e magnar ben, dei boni caponi, delle bone polastre, e dei boni straculi de vedèlo.

MAURIZIO. E tutto bon, e a bon marcà, perché se paga de volta in volta.

LUNARDO. E a casa soa; senza strepiti, senza sussuri.

MAURIZIO. E senza nissun, che v'intriga i bisi.

LUNARDO. E nissun sa i fati nostri.

MAURIZIO. E semo paroni nu.

LUNARDO. E la muggier no comanda.

MAURIZIO. E i fioi sta da fioi.

LUNARDO. E mia fia xè arlevada cusì.

MAURIZIO. Anca mio fio xè una perla. No gh'è pericolo che el buta via un bagatin.

LUNARDO. La mia puta sa far de tuto. In casa ho volesto, che la faza de tuto. Fin a lavar i piati.

MAURIZIO. E a mio fio, perché no voggio, che co le serve el se ne impazza, gh'ho insegnà a tirar suso $\mathrm{i}$ busi delle calze, e metter i fondèli alle braghesse.

LUNARDO. Bravo. (ridendo)

MAURIZIO. Sì dasseno. (ridendo)

LUNARDO. Via fémolo sto sposalizio; destrighemose. (fregandosi le mani, e ridendo)

MAURIZIO. Co volè, compare.

LUNARDO. Ancuo v'aspetto a disnar con mi. Za savè, che ve l'ho dito. Gh'ho quatro latesini, vegnimo a dir el merito, ma tanto fati.

MAURIZIO. I magneremo.

LUNARDO. Se goderemo.

MAURIZIO. Staremo aliegri.

LUNARDO. E po i dirà, che semo salvadeghi!

MAURIZIO. Puffe!

LUNARDO. Martuffi! (partono) $)^{142}$

142 ibid., Act I, v. Lunardo: Have you told him that you want to marry him off? Maurzio: I've told him. L: And what does he say? M: He says he's happy, but he'd like to see her. L: No sir, this was not our agreement (angrily) M: Oh come come, don't 
Apart from the comic yet realistic characterization of the two men, who embody the "onesto ridicolo" that Goldoni so often shows on the stage to expose certain universal flaws, this scene displays a keen attention to pacing. From initially unmeasured prose discourse, Goldoni gradually transitions into shorter and symmetrical exchanges ("E nissun sa i fati nostri/ E semo paroni nu/ E la muggier.../ E i fioi... "etc.), and ultimately ends the scene in a triumphant chorale style ("I magneremo/ se goderemo") that utilizes both rhyme and meter, two highly musical elements.

We must also note the musical stringendo created by his progressive shortening and rapprochement of entrances, almost as a fugal diminution. Such is the affinity to operatic style by the end of this scene, that

get angry, the boy will do everything I want him to do. L: Well then, whenever you like, we can get down to business. The dowry has been prepared. (...) M: Don't spend in fancy dresses, I don't want that. L: No, I'll send her to you just as she is. M: Does she have silk gowns? L: She's just got a couple strips of it. M: I don't want silk in my house. As long as I'm alive, she's going to have to wear a plain wool dress, and I don't want cloaks, or bonnets, or hoops, nor decorations, nor bows nor frills in the front. L: Good for you, God bless. I like it so myself. (...) L: There are few, who share our opinions. M: And there are few who have the money that we have. L: And they say we don't know how to enjoy life. M: Poor fools! Can they see inside our hearts? Do they really think that there is no other world but theirs, which they enjoy? Oh friend, what pleasure it is to be able to say: I have all I require, I lack nothing, and if I ever had the need, I could draw up a hundred zecchini. L: Yes indeed, and to eat well, good capons and hens, and veal hanks. M: And all delicious, and a good deal, because we pay as we acquire. L: And in our houses, without scenes or mutterings. M: And without anyone to poke around in my money. L: And nobody knows our business. M: And we are the boss. L: And the wife can't tell me what to do. M: And the children behave as children should. L: And I've brought my daughter up this way. M: And my son is a pearl. There's no chance of him wasting a penny. L: And my daughter knows how to do everything. At home, I decided she should do all sorts of jobs. She even washes the dishes. M: And my son, since I don't want him to be interested in servant girls, I've taught him how to mend his own socks, and hem his own trousers. L: Bravo (laughing) M: Yes indeed (laughing) L: Quick then, let's make this marriage happen (rubbing his hands together and laughing) M: Whenever you like. L: Then I'll expect you to dine with me tonight. You already know, I've told you. I've got four sweetbreads at home, and they'll be cooked as they should be. M: And we'll eat them. L: And we'll have a good time. M: And we'll be merry. L: Let people say that we are savage! M: Puff! (expressing marvel and disdain) L: Dimwits! (both exit) 
its final verses could function perfectly in a musical ensemble finale, accompanied by a progressive crescendo and culminating in the hasty exit of the characters with enthusiastic impetus.

The musical qualities of Goldoni's comedies appear to be one of the more distinctive traits of his authorship, and one of no coincidence given the intenstiy of his activity as a librettist. Many if not most of his mature comedies make expansive use of polyphonic techniques like those seen above, among these La bottega del caffè (1750), Il Campiello (1756, written "secondo l'uso dei drammi che si chiamano musicali" $\left.{ }^{143}\right)$, Il ventaglio (1763). In these works and many others we witness a reprise of the original meaning of the term concertato, from the Latin concertare, meaning to fight or compete: a competition, that is, of sounds and voices. ${ }^{144}$

To cite just one further example, we find the same complexity, but on a much larger scale, in the nostalgic masterpiece Una delle ultime sere di Carnovale (One of the Last Evenings of Carnival, 1762). This work is especially well-known for its allegorical design, through which Goldoni, representing himself through one of the characters, metaphorically took his leave from his Venetian public one the eve of his journey to France. Another realistic, Venetian comedy in dialect, Una delle ultime sere is situated within the domestic world of a textile merchant, and pays homage to the industry and honest profit of that trade. It is, in Goldoni's own words, "la pittura del sistema e del costume di quel ceto di persone." 145

The entire plot unfolds within one evening during Carnevale, the central event being a convivial dinner followed by festivities and games. This comedy like few others thrives on the interaction of groups and exploits the close interconnection of parallel sub-plots. Perhaps the largest, and most prolonged ensemble of Goldoni's entire output can be found in the second Act. Marked Tutti, it is a theatrical feat of gigantic

143 Carlo Goldoni, Il Campiello, Preface.

144 For further reading on the uses of this term, and its connections to Goldoni's output, see Pier Mario Vescovo, "Tarasca. Tra Napoli, Venezia, e L'europa" in Drammaturgia, XI / n.s. I - (Florence: Firenze University Press, 2014); 193-215.

145 Carlo Goldoni, Una delle ultime sere di carnovale. "The Author to his Readers." (...) the portrait of the system and customs of that class of people. 
proportions, employing virtually all characters uninterruptedly for all of seven scenes. The central frame is a game of cards that brings all together around the same table, and characters are strategically distributed by couple so that each pair may continue their own sub-plot while the broader action progresses with the game.

In the comedy, Goldoni represents himself through Anzoletto, a young fabric designer of great skill, the source of ideas from which others weave together the final product. Goldoni draws the parallel to playwriting explicitly: "I Comici eseguiscono le opere degli Autori, ed i Tessitori lavorano sul modello de' loro Disegnatori." ${ }^{146}$ Such is the skill of Anzoletto (though covered by modesty), that he has been called to "Moscovia" (Moscow) to take up his trade in that place, where, as in Parisian theatres, demand for Italian artistry is high. Many things still tie Anzoletto to Venice, however, including the love of Domenica, an authentic putta de campielo.

A central component of the work, seasoned by secondary plot threads between other characters, remains the predicament of separation that threatens the young lovers. The card tournament, an open game that nonetheless affords privacy as each team strategizes in secret, becomes a pretext ripe with possibilities for the advancement of their relationship. The brief excerpt below illustrates the manner in which Goldoni embeds important progress of action (a resolution between two lovers) within an exteriorly fixed scene:

MARTA. Tocca a far le carte a sior'Elenetta. (dà le carte ad Elena) Via, chi manca a metter su?

ANZOLETTO. Mancheremo nualtri. (prende i quattro soldi)

MARTA. (Mo i compatisso, poverazzi!)

ANZOLETTO. (Se la savesse, quanto che me despiase).(a Domenica)

DOMENICA. (De cossa?)

ANZOLETTO. (De doverla lassar). (mettendo i soldi nel piatto)

DOMENICA. (Busiaro!) (ad Anzoletto)

ELENETTA. Che la leva. (a Polonia, dandole le carte perché alzi)

MARTA. (Siora Domenica, come vàla?) (a Domenica)

DOMENICA. (Qua no se sente altro, che de le busie). (a Marta)

146 ibid. Actors perform the works of Authors, and Weavers work on the models of their Designers. 
MARTA. (Se sè un putto civil, tratè almanco con sincerità). (ad Anzoletto) ANZO-

LETTO. (Per farghe véder, che no son busiaro, ghe farà una proposizion). ( $a$ Domenica, che senta anche Marta)

DOMENICA. (Che xè?)

ANZOLETTO. (Vorla vegnir in Moscovia con mi?) (come sopra)

MARTA. (Sì ben, che l'accetta. Nol dise mal). (a Domenica)

DOMENICA. (Come?) (ad Anzoletto)

ANZOLETTO. (Col consenso de so sior padre). (come sopra)

MARTA. (Se gh'intende). (a Domenica) DOMENICA. (Sposai?) (ad Anzoletto)

ANZOLETTO. (No vorla?) (come sopra)

MARTA. (Bravo, bravo dasseno). (ad Anzoletto, rimettendosi al giuoco)

AGUSTIN. Spade, che la vegna. (giuocando)

DOMENICA. Spade? Chi zoga spade? (con allegria)

AGUSTIN. Mi; el cinque de spade.

DOMENICA. E mi el cavalo. (allegra butta giù la carta)

MARTA. L'aspetta, che no tocca a ela. (a Domenica) (Adesso la se confonde per l'allegrezza). Via a lori. (a Bastian e ad Alba) etc. ${ }^{147}$

The sheer quantity of parenthesis in this excerpt denotes the author's constant use of asides, a dramatic strategy often found in opera, which enlivens and quickens the pace of the discussion. Goldoni walks a line of equilibrium within the three-part conversation and the juxtaposition of the trio to the ongoing game. The occasional intrusion of other characters thereby creates the illusion of simultaneity. Here we witness an

147 ibid., Act II, iii. Marta: It's my turn to give the cards, Ms. Elena. Now, who's missing them? Anzoletto: We are (takes four coins). M: (I feel for them, poor things!) A: (If only you knew how sorry I am) (to Domenica). Domenica: (What for?) A: (For having to leave you) (putting the coins in the dish) D: Liar! (to Anzoletto) E: Pick it up (to Polonia, giving her a card to pick up) M: Ms. Domenica, how is it going? (to Domenica) D: (I'm hearing nothing but lies) (to Marta) A: (So you see that I'm not a liar, let me make you a proposal) (to Domenica, but so that Marta hears too) D: What is it? A: Would you like to come to Moscow with me? (as above) M: (Oh yes, you should accept. It's not a bad idea) (to Domenica) D: What? (to Anzoletto) A: With the consent of your father, of course (as above) M: Now you get it (to Domenica) D: Married? (to Anzoletto) A: Don't you want to? (as above) M: Good, good for you, in earnest (to Anzoletto, going back to the game) Ag: Spades, bring it on (playing) D: Spades? Who's playing spades? (happily) Agustin: I am, the five of spades. D: Then I'll play the horse (happily throws down her card) M: Wait, it's not your turn (to Domenica) (Now she's so happy, she's confused). Over to you (to Bastian and Alba) etc. 
ensemble technique altogether different from the verbal crescendo of $I$ rusteghi, but no less effective. While vocal overlap can be easily created in musical ensembles, the illusion of simultaneous discourse is still effectively rendered in prose, a tangible link between opera theatre and comedy. So rich are the possibilities afforded by this polyphonic design, that Goldoni adheres to this strategy for the entire act.

Connections between comedy and opera theatre are not only present in Goldoni's use of ensembles; Una delle ultime sere di carnovale also reflects his modernized serio style in the detectable presence of melancholic tones- and this work is not the only comedy in which serio is prominent, as we shall see. Serio elements are no longer of Metastasian stamp, by this point long abandoned, but rather are characterized by heightened intimacy, introspection, often self-doubt and confusion ("no so cossa dir"148), and they evoke pathos in response to candid emotion. The monologue is a typical device in these cases, as for example:

\section{MARTA e DOMENICA}

MARTA. Siora Domenica, cossa gh'àla intenzion de far?

DOMENICA. No so gnanca mi.

MARTA. Ma pur?

DOMENICA. Vorla, che andémo dessuso anca nu?

MARTA. Quel che la comanda.

DOMENICA. La resta servida, che adessadesso vegno anca mi.

MARTA. Vorla restar qua?

DOMENICA. Un pochetto. Se la me permette?

MARTA. La se comoda. (Ho capio; la se vol conseggiar da so posta. Che la varda de no far pezo. Ho sempre sentio a dir, che amor xè orbo; e chi se lassa menar da un orbo, va a pericolo de cascar in t'un fosso). (parte) $)^{149}$

148 ibid., Act I, xv. "I don’t know what to say,” spoken by Anzoletto, unsure whether to remain for love or leave for honor.

149 ibid., Act I, xviii. Marta: Ms. Domenica, what do you resolve to do? Domenica: I don't know M: and yet? D: Would you like to go upstairs to join the others? M: Whatever you prefer. D: Alright then, I'll be up shortly. M: Do you prefer to stay here? D: Just a little bit. Do you mind? M: As you wish. (I understand, she wants to counsel herself. Let's hope she doesn't make matters worse. I've always heard it said, that love is blind; and who is led blindly risks falling into a ditch) (exits). D (alone): I don't know what to do. I don't want him to go; but I wouldn't want to be the cause, if he were to lose his fortune. Of course, there is this embroiderer who 
DOMENICA. No so quala far. No voria, che l'andasse; ma no vorave gnanca esser causa mi, che ' 1 perdesse la so fortuna. Certo, za che se vede, che sta recamadora gh'ha corrispondenza in Moscovia, se poderia farghe parlar per qualchedun, e obligarla a scriver de là, che nol sa, che no l'è bon, che ghe n'è de meggio... E mi, che a Anzoleto ghe voggio ben; mi saria capace de farghe perder el so conceto? No, no sarà mai vero. Che 'l vaga, se l'ha d'andar; patirò, me despiaserà; ma pazzenzia. No faria sto torto né a lu, né a nissun, se credesse de deventar principessa. No, no certo; patir, crepar; ma rassegnarse al Cielo, e perder tutto, più tosto che far una mala azion. (parte)

In these brief scenes, the opening dialogue functions almost as an introductory recitative duet, and Domenica's monologue as a solo aria. Our grieving heroine of noble resolve is no longer an aristocratic prima donna, but a humble seamstress within a guild of artisans in a dialectal world. Yet, her piece reflects the same interior conflict, sadness, longing, and ultimately the same resolution of self-sacrifice that are emblematic of the true parte seria; nor should the use of Venetian be seen as a detraction from the weight of her words. While elsewhere Goldoni mixes dialects with standard Italian for comic contrast or caricature, this comedy, as his other Venetian works, shares no affinity to that purpose. Rather, it is simply the realistic representation of the world of the author and his audience (not to mention the fact that Venetian was once an international language in Europe, and that, as also testified by Neapolitan comedy, dialect did not pertain only to popular sphere at the time). Thus, Domenica's resolve, "patir, crepar; ma rassegnarse al Cielo, e perder tutto" (to suffer, to die, but to resign myself to the Heavens, and lose everything) carries the full weight of a dramatic serio and creates an aura of pathos typical of the new larmoyant fashion.

The shadow of impending departure that looms over Una delle ultime sere di carnovale provides ample opportunity for similar empathic episodes throughout the work, such that an overarching hue

has contacts in Moscow, and we could make her speak to somebody, and write over there that he doesn't know anything, that he's not capable, that they could find someone better...But I, who love Anzoletto, would I be capable of ruining his prospects? No, this will never be. Let him go, if he must; I'll suffer, I'll be sorry; but so be it. I cannot betray him nor anyone, even if I thought it would make me a princess. No, no indeed, to suffer, to die, but to resign myself to the Heavens, and lose everything, rather than commit a crime. (exits) 
of nostalgia can be said to characterize the autobiographical comedy as a whole. Notably, elements of serio or larmoyant as we find in Una delle ultime sere do not appear exclusively in later comedies. As in opera theatre, precocious symptoms of Goldoni's mature style can be traced to relatively early works. The prose comedies that, like drammi giocosi, reap benefit from the inclusion of serio are many.

Among these, an example of particular strength is Le avventure della villeggiatura (The Adventures of Vacationing, 1761, part two of the famous trilogy that includes Le smanie per la villeggiatura (The Yearning for Vacation) and Il ritorno dalla villeggiatura (The Return from Vacation)), in particular for the serio character Giacinta. Portrayed as a comic flirt in the first comedy, in Le avventure Giacinta undergoes radical transformation. Her role becomes tragic as, torn between her love for Guglielmo and her promise of marriage to Leonardo, she is forced to renounce her feelings in order uphold her engagement. To her predicament Goldoni adds the additional pain of witnessing her lover ultimately promised to another woman. The author portrays her as "incantata, oppressa, avvilita" (in the words of her servant, "ella è così melanconica"150). In an extended dialogue, Goldoni colors Giacinta's role with a strong language of suffering:

GIACINTA. (...) Uso ogni arte perché egli non se ne accorga, ma ti giuro ch'io patisco pene di morte. Quel dover usar al signor Leonardo le distinzioni che sono da una sposa ad uno sposo dovute, e vedere dall'altra parte a languire, a patire colui che mi ha saputo vincere il cuore, è un tale inferno, che non lo saprei spiegare volendo.

BRIGIDA. Ma come ha da finire, signora mia?

GIACINTA. Questo è quello ch'io non so dire, e che mi fa continuamente tremare. BRIGIDA. Finalmente ella non è ancora sposata.

GIACINTA. E che vorresti tu ch'io facessi? Che mancassi alla mia parola? Che si lacerasse un contratto? L'ho io sottoscritto. L'ha sottoscritto mio padre. È noto ai parenti, è pubblico per la città. Che direbbe il mondo di me? ${ }^{151}$

150 Carlo Goldoni, Le avventure della villeggiatura, Act II, i. Transfixed, oppressed, mortified.

151 ibid. Act II, i. Giacinta: I use every art so that he [her betrothed Leonardo] doesn't notice, but I swear to you, I am suffering the pains of death. To have to give Leonardo the distinctions owed to a husband by his wife, and to see the other languish, to see suffer the man who has conquered my heart, is such great torment, that I 
In addition to familiar manifestations of trembling and anguish, the pathetic element of doubt and indecision is carried throughout the work ("sono così confusa"), aggravated in this dialogue by a feeling of powerlessness beneath the oppression of the passions and the confines of social contracts that cannot be breached. Giacinta's internal illness even becomes manifest in physical symptoms as she refuses food and experiences headaches in the manner of a tragic lover.

To use Goldoni's own words, the role of Giacinta in Le avventure della villeggiatura is "una lunga disperazione, un combattimento di affetti, un misto d'eroismo e di tenerezza," 152 precisely the elements of a modern, realistic serio. The psychological realism of her lines contributes to the dramatic impact of her role and unequivocally seals the comedy as an exquisite mixture of buffo and serio, as we have often encountered in the drammi giocosi. The comedy also makes ample use of ensembles, with typical theatrical feats such as asides and parallel conversations, as well as the convergence of all characters at the conclusion of acts in operatic chorale style.

Coincidentally, the idea of villeggiatura, vacation in the countryside much in vogue among well-to-do Venetian families, is persistently made the object of comic critique in Goldoni, who in particular denounces the excesses of this fashion. The tradition is targeted not only in the other comedies of the villeggiatura trilogy (Le smanie and $I l$ ritorno) but in numerous other comedies as well, including La castalda (The Gastald, 1751), I malcontenti (The Dissatisfied, 1755), and La villeggiatura (a distinct work, 1756). Goldoni also tackles the issue in music, beginning with the dramma comico L'Arcadia in Brenta (Arcadia on the River Brenta, 1749).

Looking back further, prototypical antecedents of serio and larmoyant can be found as early as La putta onorata (The Honorable Venetian

could describe it even if I wanted to. Brigida: But how will it end, my lady? G: This is what I don't know, and what makes me tremble constantly. B: In the end, you are not yet married. G: And what would you have me do? Should I betray my word? Should I break a contract? I've signed it. My father has signed it. It's known by to our family, it's public in town. What would the world say of me? etc.

152 ibid., Act III, xvi. (...) a long desperation, a contrast of affections, a mixture of heroism and tenderness. 
Girl), written in the same year as Goldoni's first dramma giocoso, La scuola moderna. A largely successful

Venetian comedy that mixes Italian with dialect and masks with original characters, La putta onorata was premiered at the Teatro $S$. Angelo in 1749 and given for 22 consecutive nights. Giuseppe Ortolani has seen in the work "la rivendicazione della virtù del popolo nostro [veneziano] offesa, con triste tradizione, dalla leggerezza e dalla maldicenza dei viaggiatori stranieri," ${ }^{153}$ and the protagonist embodies Goldoni's attempt to create a positive image of Venetian women.

In a letter to his publisher Bettinelli, Goldoni clearly delineates the high level of realism of the work, "avendo io in più luoghi imitato le azioni e i ragionamenti della minuta gente." As in the early intermezzo La Birba, Goldoni again explicitly derives his characters from the direct, 'natural' imitation of real-life models: "i Gondolieri di Venezia...furono da me nella presente Commedia imitati con tanta attenzione che più volte mi posi ad ascoltarli, quando quistionavano, sollazzavansi o altre funzioni facevano, per poterli ricopiare nella mia Commedia naturalmente." ${ }^{54}$ Bettina, Goldoni's heroine (originally Teodora Medebach), earns the title of putta onorata as she defends her honor when, like Lucia of Manzoni's Promessi Sposi, she is abducted by a man who desires her, in this case the Marchese Ottavio di Ripaverde (already married, at that). Much of the serio or larmoyant of the work arises from Bettina's pitiable circumstances during this episode, particularly from her confusion, as from her innocence:

153 Giuseppe Ortolani, "Introduzione" to La Putta onorata in Tutte le opere di Carlo Goldoni, a cura di Giuseppe Ortolani, vol. II. (Milano: Mondadori, 1936). (...) the vindication of the virtue of our people, offended, in a sad tradition, by the carelessness and malicious gossip of foreign travelers.

154 Carlo Goldoni, La Putta onorata, "Lettera dell'Autore al Bettinelli." I have in several places imitated the manners and discourse of the common people. (...)the Gondoliers, in the present work imitated with such great attention that many times I set myself to observing them, listening to their conversations when they argued, when they played, and when they did other things, to be able to recopy them in my Comedy naturally. 
Oh povereta mi! Cossa mai sarà de mi? Dove songio? In che casa songio? Chi mai xe stà che m'ha menà via? (...) Povero Pasqualin, dove xestu, anema mia? Perché no viestu a agiutar la to povera Betina, che te vol tanto ben? ${ }^{155}$

In her Venetian spirit, Bettina has little of the fearfulness or timidity of Manzoni's Lucia. As a true heroine, she is quick to act in adverse circumstances, and her stricken monologue (cited above) soon transforms grief into rage, even resolving to inflict physical punishment on her oppressor ("ghe darò...tante sgrafignaure, che ghe farò piover el sangue"156). The changeability of her role not only adds complexity to an original character but moreover contributes to an overarching sense of continual propulsion. In this comedy, in which action is dense and events are often hurried, characters change disposition within the span of a few lines. La putta onorata is in essence a sequence of rovesciamenti, as also testified by Goldoni's resolution of the work with a fantastic peripezia. The third Act uncovers two mistaken paternities: Pasqualino, Bettina's lover, while believed to be the son of a gondolier, in reality is the heir of the rich merchant Pantalone; conversely, the alleged son of Pantalone (Lelio) is in fact the real son of the gondolier.

More than Goldoni's inventiveness alone, the dramatic nature of these events and of La putta onorata as a whole reflects a growing appreciation for romanzesco elements. The combative heroine, the continual flow of action, and events such as infants swapped in the cradle or the abduction of a maiden, all point towards the adventurous, almost incredible, brand of action characteristic of new $18^{\text {th }}$ century novels. Of course La putta onorata is still an early work and in more mature comedies and drammi giocosi Goldoni will often prefer more realistic solutions. However, elements of romanzesco will continue to inform some of the author's dramatic choices, particularly in new strains of sentimentalism.

155 ibid., Act II, iii. Oh wretched me! What will become of me? Where am I? In whose house am I? Who's taken me here? (...) Poor Pasqualino, where are you, my soul? Why don't you come to the aid of poor Bettina, who loves you so? etc.

156 ibid., Act II, iii. I'll scratch and swipe at him so much, that his blood will pour. 


\section{ii. Comedies that became drammi giocosi}

The close relationship between Goldoni's comedies and libretti is not only detectable in the shared realism, buffo and serio, and dramatic techniques that we have seen, but confirmed by several cases of direct translation from one genre to the other. Most often, Goldoni drew drammi giocosi from his comedies, though some themes first explored in his libretti also served as the foundation for later works of prose theatre. Seen within the larger context of the author's entire output, occurrences of direct translation are not numerous, yet they can be traced from his early years through his mature production.

Naturally, not all instances of adaptation reflect the same degree of adherence to their original. The early intermezzo Il quartiere fortunato (The Lucky Neighborhood, 1744), for example, cannot be considered a direct source but rather the precedent for L'amante militare (The Military Lover, a reform comedy dated 1751). In the same way, other comedies do not explicitly testify the use of a libretto as a model, yet reveal a high degree of thematic affinity. The previously examined La ritornata di Londra (1756), for example, exploits the comic yet critical topos of a woman pursued by an entourage of suitors taken up in several later prose works. The larger outline of the plot is faithfully recovered in L'apatista (The Indifferent, 1758), in which the countess Lavinia, like her musical controfigura Petronilla, is encircled by gentlemen of diverse yet complementary nature. By no coincidence, the typified character traits of the men, one an impetuous captain, another the antithetical, apathetic philosopher, allow comedy and character study (particularly of the calibrated indifference of the latter) at the same time. Also akin to the peculiarity of La ritornata di Londra, all characters are of noble extraction; their tone is thus consistently elevated, though the high level of linguistic propriety is not always maintained in their actions. A final element of affinity between the two works resides in their reduced cast: Goldoni's libretto is scored for seven characters, and the comedy contains six. While a restrained number of characters is necessary in opera, where every plot element is dilated by music, a small cast is rather atypical in Goldoni's prose theatre, especially at this mature stage. The relative simplicity of L'apatista is clearly intended 
to facilitate performance, particularly as the comedy, commissioned by the Marquis Francesco Albergati, was written for the semi-professional troupe of actors that performed in the private theatre of his villa at Zola.

A looser resemblance with La ritornata di Londra can also be found in La donna stravagante (The Bizarre Woman), a comedy in verse given during the same carnival season as the dramma giocoso (1756). Notwithstanding metrical constraints, this comedy appears particularly well developed in its characterizations and gained a positive reception at the Teatro San Luca. Its protagonist Livia is complex and original, but as an orphaned girl under the guardianship of her uncle, however strong willed, she has little in common with the emancipated diva Petronilla. More noteworthy is the fact that from La donna stravagante, Goldoni derived a second comedy, La donna bizzarra, given in the same season as L'apatista (1758). La donna bizzarra, also written for the Marchese Albergati, again presents a noblewoman (this time widowed) amid an entourage of suitors. The number of gentlemen has now grown to four, none of whom are ultimately desirable. As Goldoni himself admits, the comedy was written in undue haste, therefore recycles choice scenes from the earlier La donna stravagante. Poetically put, "qualche volta gli autori sono costretti a valersi del loro baule, come fanno i Maestri di musica." ${ }^{157}$ For this reason, the comedy preserves the versi martelliani of its source, though the characters have been modified and the plot somewhat reworked, so that Goldoni may assure, "senza scrupolo ho potuto dargliela per cosa nuova, e per tale posso ora darla alle stampe." 158

The most prominent point of distinction between the two works is the declared critical intent of the second, which sheds a cautionary light on the protagonist, as on her suitors:

La bizzarria di questa mia Donna non dipende né da iracondia, né da vivezza di spirito, ma da capriccio, che vale a dire da una testa mal regolata. Vi sono delle Donne e degli Uomini di tal carattere; meritano di esser corretti, ed io ho avuto animo di far del bene a chi n'ha bisogno, e di far ridere chi è esente da tal difetto. Ma chi sa che non rida degli altri chi è più attaccato da una simile malattia? Raro

157 Carlo Goldoni, La donna bizzarra, "The Author to his Readers." Sometimes, authors have to dip into their trunk just like musicians do.

158 ibid. Without scruple, I can deliver it as a new work, and as such send it to print. 
è lo specchio che disinganni, l'amor proprio vi mette un velo, e l'abituazione fa che si sente l'odore degli altri, e non si fa caso del nostro. ${ }^{159}$

We find in this introduction a clear reprise of Goldoni's Horatian belief in the moral potential of comic theatre. Of particular note is the absence of differentiation between flawed women and men. In a spirit close to $L a$ ritornata di Londra, the panorama of flaw is of universal scope.

Moving beyond these primary elements of contact between Goldoni's two theatres, we may now consider works that more explicitly testify direct translation from one genre to the other. Goldoni first unequivocal derivation of a dramma giocoso from a reform comedy is Lo speziale (The Apothecary, 1755), built from elements of La finta ammalata (The False Patient, 1751). As its opening date betrays, the comedy was one of sixteen such works famously turned out in a single season for Girolamo Medebach, while the dramma giocoso, first premiered at the Teatro S. Samuele with music by Vincenzo Pallavicini and Domenico Fischietti (it was not uncommon for different composers to set serio and buffo roles), is readily available even today thanks to the musical rendition by Franz Joseph Haydn.

With the expansion of every verse in song, Goldoni's reworkings from a prose original for musical theatre always logically appear as reductions. In this particular case, however, the author does not condense the entire plot while maintaining its most prominent features as he will do elsewhere, but instead spins an entirely new libretto from a single element of the comedy, the character of the apothecary. La finta ammalata revolves around a hypochondriac whose only real malady is love, and the attempts of an équipe of doctors (an honest one and two corrupt foils), to procure her remedy. With three doctors, an anxious father, and a surgeon in the picture, the apothecary, whose character is nevertheless well developed, necessarily remains secondary in

159 ibid. The oddity of this leading lady does not stem from temper or vivacity of spirit, but from whim, in other words from a mind that is not well governed. There are women and men of this type; they deserve to be redressed, and I have a mind to give help to who is in need, and to entertain those who are exempt from these flaws. But who can say if he who laughs the most is not afflicted by the same illness? Rare is the mirror that disenchants, for pride often veils it, and habit leads us to detect the smell of others, but does notice our own. 
an already male-dominated plot. He is an accomplice of the false doctors, but the more artisanal nature of his profession does not grant him their status. In synthesis, the comedy is an attack on false medicine, and those false doctors who, simulating abstruse expertise, make their fortune treating patients with invented remedies. While the apothecary seldom has the opportunity to treat patients directly, he too participates in the fraud by lobbying for a greater number of prescriptions and for remedies of greater cost.

Lo speziale takes a cue precisely from this aspect of the La finta ammalata, yet the comedy's polemical bent is notably softened in favor of the introduction of amorous sub-plots. While La finta ammalata sees all characters revolve around a single protagonist and her desires, $L o$ speziale is built upon the parallel intrigues between the apothecary's daughter, another young girl he looks after, and their respective romantic partners. Continuity between comedy and libretto is thus manifest uniquely in the transposed apothecary Sempronio, who shares with his predecessor crucial aspects of character, namely a scarcely professional predilection for the latest gossip, and reliance upon the gazzetta (a sort of almanac) for his medical authority. Despite the amorous intrigues new to Lo speziale, however, the original theme of false medicine is preserved at least in part through a new character, the assistant pharmacist Mengone. While Mengone harbors none of the contrivance of the profit-seeking doctors of La finta ammalata, being illiterate and unable to decipher prescriptions, he too invents cures in like manner.

A much higher level of correspondence between comedy and opera can be detected in the dramma giocoso La donna di governo (The Governess, 1761), reworked from a comedy of the same title written for the Teatro S. Luca in 1758. Of the text we have spoken earlier (the score unfortunately has not survived), noting in particular its desolate panorama of moral corruption, headed by the unscrupulous protagonist Corallina. The introduction to the comedy befits the negative heroine of the libretto as much as its own protagonist:

Eppure anche i tristi caratteri s'hanno da far conoscere sulla Scena, per rimproverarli, per opprimerli, per isvergognarli. L'arte insegna in tal caso a moderarne l'aspetto, a estendersi fin dovela modestia il permette, e lasciar campo all'uditore di concepire il di più, che non apparisce sul palco e che l'Autore ritiene nella penna per onestà e per dovere. Si trovano delle Donne pur troppo, che costrette 
dallo stato loro a vivere del pane altrui, se ne abusano malamente, e guadagnando l'animo del Padrone, lo conducono dove l'ambizione o il mal costume le porta. Ho veduto cogli occhi miei delle Famiglie in disordine, in disunione, in rumori grandissimi per causa di quelle lusinghiere serventi, che aspirano a dominare. Entrano in casa per Governanti delle Famiglie, e il loro governo tende per ordinario a fabbricare la propria fortuna sulle rovine dei Figliuoli medesimi. Succede poi bene spesso, che altri divori alla Governante ciò ch'ella con mala arte procaccia, ma non sì spesso accade ch'ella finisca con quel rossore e con quel castigo che merita, poiché gli acciecati Padroni lasciano talora anche dopo morte la memoria della loro fatuità e debolezza, beneficandole per le loro insidie, e per le loro studiate simulazioni. Io ho avuto in vista in questa Commedia di smascherare alcune di queste false zelanti per li loro Padroni, e d'illuminare altresì que' tali che più credono ad una mercenaria adulatrice servente, anziché ai Parenti, agli Amici, ed al loro sangue medesimo. ${ }^{160}$

Again, we are made aware of familiar notions: Goldoni's desire to denounce and redress moral corruption through the benefits of comic mimesis, and at the same time his extraction of character types from the witnessed experience of daily life ("ho veduto cogli occhi miei"). Corallina, like her prose predecessor Valentina, is one of those women who, employed by others, take advantage ("ne abusano malamente"),

160 Carlo Goldoni, La donna di governo, "The Author to his Readers." And yet, all those deplorable characters must be made known, to reproach them, to suppress them, and to give them shame. Art can in this case teach moderation, going only as far as modesty permits, and letting the listener go further in his imagination to see what does not appear on the stage, which the Author keeps closed in his pen for reasons of honor and duty. There are certain Women, unfortunately, who, forced by their condition to live off the wealth of others, take advantage savagely, and, earning their Master's soul, lead him where their ambition and dishonorable ways desire. I have seen with my own eyes Families in disorder and disunion, in great scandal for fault of those flattering servants who aspire to govern the house. They enter as Governesses for Families, and their mode of government usually tends to produce their own profit to the ruin of the children. It then occurs frequently, that another takes from the Governess what she with dubious arts has gained, though not so often does it happen that she ends up with the redness of shame and the punishment that she deserves, given that the blinded Masters leave even after death the memory of their weakness and their fatuousness, rewarding them for their schemes and their studied pretentions. In this comedy I set my sights on unmasking these actors of false zeal for their Masters, and on enlightening moreover those who give credence to such flattering mercenaries, instead of to their Families, to their Friends, and to their own blood. 
spurred by ambition, or worse, mal costume. Differently from Lo speziale, Corallina is far from the only point of contact between the prose and operatic La donna di governo. From comedy to libretto, Goldoni maintains all of the essential characters, even allowing a direct correspondence of names in the case of Fabrizio, the benestante head of the house, and Fulgenzio, the serio lover of his niece Giuseppina (in opera Rosalba). Other important characters maintained from comedy into opera include the governess's sister, the servant who is Corallina's accomplice, and most importantly the governess's lover, who reaps benefit from her deception of Fabrizio.

While the lovers of Valentina and Corallina do not share a name, their characterization is in fact identical. Goldoni not only leaves their dishonesty uncovered, but more conveniently transposes excerpts from his comedy into recitativo, carried word for word. The procedure becomes apparent from the opening of both comedy and opera, in which the lover protests:

Non so far niente...Servire? ho i miei riguardi. Son solito dal letto levarmi un poco tardi. Sentirmi comandare avvezzo non son io. Mi piace, e mi è piaciuto, far sempre a modo mio. ${ }^{161}$

The parallels continue almost identically. In comedy,

BALDISSERA. Servir non fa per me.

VALENTINA. Qualche cosa nel mondo devi pur far.

BALDISSERA. Perché? Ho vissuto finora senza far nulla, e adesso Dovrei morir di fame con una moglie appresso?

becomes

CORALLINA. Qualche cosa dei far.

RIDOLFO. Per qual ragione? Campai senza mestiere infino adesso e ho da temer con una moglie appresso? ${ }^{162}$

161 Carlo Goldoni, Comedy, I, i; Opera, I, v. I don’t know how to do anything. To serve? I have my scruples. I am used to getting out of bed late. I'm not used to taking orders. I like, and I've always liked, to do as I please.

162 ibid. In comedy: B: Serving is not for me. V: Well, you'll have to do something in this world. B: Why? I've lived until now without doing anything, and now I should 
Just as Goldoni must reduce the plot in a larger structural sense to fit five acts of comedy into three of opera, he also operates at the minute level to render his text concise enough for music. Masterfully, even while Goldoni reworks his comedy in such a high degree of fidelity, he does not preclude the use of typically operatic devices, such as the aria (Baldissera's exit in comedy becomes a solo piece in opera). In this respect, the fact that Goldoni's comedy had been written in verse (versi martelliani, a double septenary structure) appears particularly advantageous, a further motive whereby only slight changes were required for the libretto.

Textual parallels continue to the end of the scene and beyond, traceable in the interactions of the central characters, while secondary figures that occupy stage time in the comedy, namely a second sister for Giuseppina and a maternal aunt who takes up their defense, are cut by Goldoni to streamline his libretto. Certain episodes from the comedy are therefore entirely absent from the libretto, but stretches of textual parallelism resurface with regularity, preserving all the distinct character flaws of the principal figures. Considering the length of these scenes, we may consider one example representative of others, and analyze the parallels that arise as the governess interacts directly with Fabrizio.

Originally, we find:

FABRIZIO. Valentina. (come sopra)

VALENTINA. Si sfiati, se vuol, quest'animale. Egli ha da far un giorno la fin delle cicale.

FABRIZIO. Che tu sia maladetta; possa cascarti il cuore. (escendo fuori, senza veder Valentina) Dove sei, Valenti...? (scoprendo Valentina, rimane sorpreso)

VALENTINA. Eccomi qui, signore. (facendo una riverenza caricata)

FABRIZIO. Grido, grido, e non sente. (con sdegno)

VALENTINA. Grida, grida, e si sfiata. (con arroganza)

FABRIZIO. Perché non rispondete? (come sopra)

VALENTINA. Perch'era addormentata. (come sopra)

FABRIZIO. A quest'ora?

VALENTINA. A quest'ora.

Saran quattr'ore e più

starve with a wife by my side? In opera: C: You must do something. R: For what reason? I've gotten by without a trade until now, and I should fear with a wife by my side? 
Che ho fatto in questa casa levar la servitù. Ho fatto ripulire le stanze, il suolo, il tetto, Ho fatto spiumacciare le coltrici del letto, Lustrar nella cucina il rame insudiciato E han fatto queste mani il pane ed il bucato. Ma qui non si fa nulla. Qui si fatica invano. Il padron sempre grida. Che vivere inumano! Casa peggior di questa non vidi in vita mia; L'ho detto cento volte, voglio di qui andar via. FABRIZIO. Subito vi scaldate. (mansueto) VALENTINA. Mi scaldo con ragione. FABRIZIO. Non sapea che dormiste. VALENTINA. No, non vi è discrezione.

Ritrovatene un'altra che faccia quel ch'io faccio.

Se non foss'io... ma basta, fo il mio dovere, e taccio.

Del faticar sinora non mi ho mai lamentato; Spiacemi aver che fare con un padrone ingrato.

FABRIZIO. No, cara Valentina, ingrato io non vi sono.

Se ho detto quel che ho detto, vi domando perdono.

Ho questo naturale perfido e doloroso,

Facilmente mi accendo, ma poi sono amoroso;

Amoroso con tutti, e più con voi, carina.

Non so che non farei per la mia Valentina.

VALENTINA. Questa è la gratitudine che dal padron si aspetta:

Possa cascarti il cuore; che tu sia maladetta.

Mi alzo per faticare, che ancor non ci si vede,

Ed ei cogli strapazzi mi rende la mercede.

FABRIZIO. Puh, mi darei nel capo un colpo micidiale. (dandosi da sé stesso un pugno nella testa)

VALENTINA. (Batti, accoppati pure). (da sé)

FABRIZIO. Lo so ch'io son bestiale.

E voi pure il sapete, e compatir conviene

Qualche volta il difetto di un uom che vi vuol bene. ${ }^{163}$

163 Carlo Goldoni, La donna di governo (comedy); Act I, ii. Fabrizio: Valentina. Valentina: Let him run out of breath, this animal. F: Curse you, may your heart fall out (exiting without seeing Valentina). Where are you, Valenti...? (seeing her, he is surprised). V: Here I am, sir (with an exaggerated curtsy) F: I yell, I scream, and you don't hear me. (with irritation) V: You yell, you scream, and you waste your breath (with arrogance). F: Why don't you answer? (as above) V: Because I was asleep. (as above) F: At this hour? V: At this hour. It's now been more than four hours since I woke up all the servants. I had them clean the rooms, the floors, the roof, I had them shake out the beds, scrub the copper in the kitchens, and with 
In opera, all the above content is preserved, only visibly condensed:

FABRIZIO. Corallina. (Di dentro)

CORALLINA. Animalaccio. (Da sé)

FABRIZIO. Corallina. Che tu sia malede... (Esce e s'incontra in Corallina)

CORALLINA. Grazie, signore.

FABRIZIO. Grido, grido e non sente. (Con sdegno)

CORALLINA. Grida, grida e si sfiata. (Con arroganza)

FABRIZIO. Perché non rispondete? (Come sopra)

CORALLINA. Perché era addormentata. (Come sopra)

FABRIZIO. A quest'ora?

CORALLINA. A quest'ora. Saran quattr'ore e più

che ho fatto risvegliar la servitù.

Ho fatto ripulire

le stanze infino al tetto,

spiumacciar più d'un letto,

lustrar nella cucina

il rame insudiciato

e han fatto queste man pane e bucato.

Ma qui non si fa niente;

servo un padrone ingrato.

Casa peggior non vidi in vita mia.

L'ho detto e lo farò; voglio andar via.

FABRIZIO. Uh! Mi darei nel capo

un colpo micidiale. (Si dà nella testa)

CORALLINA. (Datti, accopati pur). (Da sé)

my own hands, I made the bread and did the wash. But here no work gets done, all efforts are in vain. The master always yells. What an inhuman way to live! I never saw a worse house in my life; and I've said it a hundred times, I want to leave. F: You anger so quickly (meekly) V: I anger with good reason. F: I didn't know you were asleep. V: No, there is no reserve. Find yourself another who does what I do. If it weren't for me... but enough, I do my duty, and hold my tongue. I never before complained of my toils; but I don't like having anything to do with an ungrateful master. F: No, dear Valentina, I'm not ungrateful. If I said what I did, I ask forgiveness. I am of an ill1spirited, distressed nature, I am quick to anger, but I can be loving too; Loving with all, but more so with you, sweet. I don't know what I'd do for my Valentina. V: This is the recognition I expect from my master: May your heart fall out; may you be damned. I get up to work, we've yet to cross paths in the day, that you immediately thank me with scoldings. F: Puh, I'd give myself such a blow to the head (hitting himself on the head) V: (Beat, go ahead and kill yourself) (aside) F: I know I am an animal. And you know it too, yet you must have compassion for a man who loves you. 
FABRIZIO. Sì, son bestiale.

Ma voi mi conoscete

e compatir conviene

qualche volta un padron che vi vuol bene. ${ }^{164}$

This textual evidence proves tangible contact between Goldoni's opera and prose theatre. In the transposition of scenes at a high level of fidelity, Goldoni also preserves the moral and critical intent of the comedy is his libretto. Differences between the two works, aside from the natural reduction of the acts and the elimination of auxiliary characters, are few. The most notable adjustment in content is the replacement of rage episodes in comedy with a larmoyant type of serio in the opera, advantageous in many respects. The choice for new tragic hues does not subtract from the realism of the parti serie involved, but rather enhances it as we have seen, and this ampler diversification in turn translates into greater musical variety. Furthermore, we must understand the expansion of serio as a logical dramatic consequence of Goldoni's other changes. In particular, in comedy the governess prevails over two sisters, who however can count on their mutual support and that of an aunt to ultimately resolve the plot in their favor. The necessary reductions for the dramma giocoso leave only one sister, and Goldoni removes all of her supporting characters. The tendency of Rosalba towards despair and selflpity is thus a natural consequence of her isolation, and appears a realistic reaction to her impotence.

The analogous conclusions of the two works prove that, aside from these few crucial differences, the relationship between them is one of common purpose. In particular, in opera as in comedy Goldoni preserves his commentary and condemnation of blind infatuation. Both protagonists are ultimately forgiven by a hurt but still love-struck Fabrizio, who furthermore bestows a hefty dowry upon them, as foretold: "non sì spesso accade ch'ella [the governess who takes advantage] finisca con quel rossore e con quel castigo che merita, poiché gli acciecati Padroni lasciano talora anche dopo morte la memoria della loro fatuità e debolezza, beneficandole per le loro insidie, e per le loro studiate

164 Carlo Goldoni, La donna di governo (dramma giocoso); Act I, viii. Translation above. 
simulazioni." 165 In sum, together with his augmentation of serio in the dramma giocoso, Goldoni does not hesitate to expose the real world in opera theatre in equal measure as in his comedy.

The two renditions of La donna di governo testify that Goldoni could not have seen comic theatre and opera theatre as incompatible arts, nor did he believe musical theatre to be less capable of harboring the same reformist traits and social critique at the core of his best comedies.

Il povero superbo (1755), a case of particular complexity, confirms this unequivocally. This dramma giocoso, premiered at the Teatro $\mathrm{S}$. Samuele like so many others, was not only derived from a previous comedy by Goldoni, La Gastalda (1751, published by Bettinelli amid bitter controversies in '53), but served, in turn, as the basis or 'twin work' for another prose comedy, La Castalda (1754-55). This latter comedy, deliberately entrusted by the author to the florentine editor Paperini, bears clear correspondance of title, albeit 'tuscanized,' with La Gastalda, but the common ground between them does not go much beyond- likely a direct consequence of the conflicts of interest in copyright claims arisen when Bettinelli published the 'original' of his own accord.

Correspondances and divergences between the two comedies, and between the comedies and the libretto, have already been weighed exhaustively by Lucio Tufano, who has even sublimated Goldoni's process of rewriting in a series of very clear diagrams. ${ }^{166}$ It is not necessary therefore to repeat that information here, but the case of $i l$ povero superbo must nonetheless be brought to the forefront as an additional, indisputable, witness to the near noexistent line of distinction between comedy and libretto in Goldoni's creative process. The chronology of the works in question imply that Goldoni inevitably drafted comedy and libretto side by side, a circumstance apparently confirmed by the fact that, singularly enough, Goldoni did not append his name (Arcadian or otherwise) to this particular libretto. Good lawyer that he was, this only logical motivation for this choice must have been an effort to avoid

165 Carlo Goldoni, La donna di governo (comedy), previously cited.

166 For further reading see Lucio Tufano, Introduzione a Carlo Goldoni, Drammi comici per musica, vol. 3 (Venezia: Marsilio, 2016). 
formally connecting himself to a text so similar to a new comedy yet written for another theatre (Grimani's newly restored S. Samuele), in other words a text that could risk violation of the terms of exclusivity of his contract with Vendramin.

We come finally to Goldoni's dramma giocoso La buona figliuola (The Good Girl), adapted from his comedy La Pamela. The prose version has been extensively noted in scholarship particularly for its tragic or pathetic accents, and the opera derived from it, which preserves and augments these traits, represents a significant innovation in the direction of Goldoni's reform, and more broadly in the direction of a new, contemporary, and realistic opera theatre. La buona figliuola and even more so its original, La Pamela, are important indicators of the new influence of English novels on the European imagination, and most importantly of the new larmoyant style previously defined. As the author announces in his Prefazione, "questa è una Commedia in cui le passioni sono con tanta forza e tanta delicatezza trattate, quanto in una Tragedia richiederebbesi," $" 167$ reason for which AnnaMaria Finetto asserts, "ascrivere la Pamela di Goldoni al genere "commedia" è ...per certi aspetti riduttivo." 168 Derived by Goldoni from Samuel Richardson's epistolary novel, Pamela or Virtue Rewarded (1741), La Pamela overturns all of the comic irreality of the traditional serva padrona. Another legacy of Goldoni's prodigious year of the sixteen comedies, it was first given in 1750 with Medebach. A sequel of even greater success, La Pamela maritata (Pamela Married), followed ten years later (immediately translated into German, Spanish, and French), prompting editors Bettinelli and Paperini to subsequently list the original as Pamela fanciulla (Pamela Nubile) for reasons of distinction.

Before considering Goldoni's operatic adaptation (with particular regard to its treatment of serio), a word must be said regarding the author's intervention on Richardson's original. The story of Pamela is

167 Carlo Goldoni, La Pamela, Forward. This is a Comedy in which the passions are treated with such force and such delicacy as would be required in a Tragedy.

168 AnnaMaria Finetto, "La Pamela e La Buona Figliuola: Il Linguaggio Patetico di Goldoni”, in Studi Goldoniani quaderno 8 (Venezia: Casa di Goldoni e Istituto di Studi Teatrali dei Musei Civici Veneziani, 1988); 107. Ascribing Goldoni’s Pamela to the genre of comedy is in some ways reductive. 
one of contrast between internal affection and social obligation, and it confronts the potential incompatibility between $18^{\text {th }}$ century class structure and Enlightenment philosophy. The heroine, whose letters to home make up the novel, is a modern English putta onorata, of humble origin but noble spirit. With the protection of a noblewoman who comes to love her as a daughter, Pamela receives an excellent education and all that she needs to function in high society. Her fortune changes dramatically at the death of the Lady, as Pamela becomes victim of the violent temperament of her son, torn between his love and admiration for Pamela's character and contempt for her origins. Pamela's virtue never falters, and, after many tempestuous ordeals including attempted physical assaults and abduction (the hallmark of a romanzesco work), rewards her with a felicitous union to the son of her late mistress, transcending every social barrier and norm.

An extremely popular tale, Richardson's novel was partially reworked in Italy by Pietro Chiari and the Neapolitan Francesco Cerlone (1730-1812) among others. Cerlone, who worked as a librettist in Rome from 1750, like Goldoni authored two comedies, Pamela nubile and Pamela maritata. It is unknown whether the authors ever interacted, but it is certain that they shared a composer, Giovanni Paisiello, who first set Goldoni's Il mondo della luna.

Goldoni's own rendition of Pamela boasts a long legacy. His comic reduction was published in England as early as 1756 (editor John Nourse) together with another Medebach comedy, Il padre di famiglia (The Family Father, 1750), within a bilingual edition interestingly advertised as A New Method of Learning the Italian Tongue. More importantly, scholars have identified Goldoni as a source for subsequent Pamela adaptations throughout Europe, including Voltaire's L'Ecossaise (The Scottish Girl, 1760) and Pamela, ou la vertu récompensée (Pamela, or Virtue Rewarded) by François de Neufchâteau (1793) in France. ${ }^{169}$

Goldoni's changes for opera thetare are necessarily oriented towards a reduction of content. His comedy therefore begins long after the death of Pamela's kind mistress, almost at the eve of the union between the

169 T. Keymar, P. Sabor, Pamela in the Marketplace: literary controversy and print culture in eighteenth century Britain and Ireland. (New York: Cambridge University Press, 2005); 138. 
maiden and the heir Bonfil. Consequently, Bonfil retains some of Richardson's characterization in his rash temper, but displays none of the violent behavior of his early days. Goldoni prefers to highlight instead a mature state of respectful admiration for Pamela, intensified by an all-consuming love and dependence on her presence, and a resulting tendency towards melancholic humor. The action is entirely carried out within the walls of Bonfil's home; dramatic episodes of physical nature, such as Pamela's abduction, are wholly excluded in favor of emphasis on interior conflict, which constitutes the core of the action. These changes are by no means, however, the most noteworthy.

More than a mere reduction, Goldoni also directly alters Richardson's plot. Most notably, he removes the political undertones of the original in effacing its radical message of equality. Goldoni's Pamela, unlike her predecessor, is discovered through a coup de scene to be of noble blood. She does not, therefore, attain marriage directly because of her personal merits, but only thanks to a deliverance from her social status in which she plays no active role. Not only does Bonfil not transcend the constraints of his social order in acknowledgment of her moral worth, but moreover Pamela's virtuous conduct is retrospectively framed almost as a physiological consequence of her blood, therefore her free will undermined, and its merit reduced. Goldoni explains:

Il premio della virtù è l'oggetto dell'Autore Inglese; a me piacque assaissimo una tal mira, ma non vorrei che al merito della virtù si sagrificasse il decoro delle Famiglie. Pamela, benché vile ed abbietta, merita di essere da un Cavaliere sposata; ma un Cavaliere dona troppo al merito di Pamela, se non ostante la viltà de' natali, la prende in isposa. Vero è che in Londra poco scrupolo si fanno alcuni di cotai nozze, e legge non vi è colà che le vieti; ma vero è non meno, che niuno amerà per questo che il figliuolo, il fratello, il congiunto sposi una bassa femmina, anziché una sua pari, quantunque sia, più di questa, virtuosa quella e gentile. ${ }^{170}$

170 Carlo Goldoni, La Pamela, "The Author to his Readers." The reward of virtue is the subject of the English author; I liked it very much, but I wouldn't want to sacrifice the dignity of Families to the merit of virtue. Pamela, while vile and abject, merits that a Gentleman should marry her; but a Gentleman would give her too much merit, if her were to marry her in spite of the lowliness of her birth. It is true that in London such a union does not raise concern, and there is no law there to forbid it; but it is no less certain that no one because of this would like for his 
This decision may appear uncharacteristic, especially in light of the Enlightenment ideals we often associate with Goldoni's comedies. It becomes more comprehensible, however, when we remember that $L a$ Pamela is a relatively early work, written during Goldoni's first contract as a dramatist. Preservation of all aspects of Richardson's original would easily have ascribed a radical stance to a young author just beginning to gain the goodwill of Venetian spectators. The delicacy of this societal matter, and likely a certain discomfort with the issue, is betrayed by the ambiguity of the remarks that follow:

Non so, se su tal punto saranno i perspicacissimi ingegni dell'Inghilterra di me contenti. Io non intendo disapprovare ciò che da essi non si condanna; accordar voglio ancora, che coi principi della natura sia preferibile la virtù alla nobiltà e alla ricchezza, ma siccome devesi sul Teatro far valere quella morale che viene dalla pratica più comune approvata, perdoneranno a me la necessità, in cui ritrovato mi sono, di non offendere il più lodato costume. ${ }^{171}$

Goldoni's language suggests a high regard for the 'great minds' of England, and his request for pardon, however rhetorical, leaves open the possibility of a divarication between his personal beliefs and the constraints of his first professional debut. What is more, while Goldoni resolves the action in a less socially charged manner, he does not wholly eliminate egalitarian notions from his comedy, offered by various characters throughout the work. An unequivocal example is the following tirade spoken by Pamela's governess, which appears almost as a prose exit aria:

Che si abbia a morire per salvar l'onore, l'intendo; ma che sia disonore sposare una povera ragazza onesta, non la capisco. Io ho sentito dir tante volte che il mondo sarebbe più bello, se non l'avessero guastato gli uomini, i quali per cagione

son, brother, or other relation to marry, instead of a lady his equal, a lowly woman, even if she were more virtuous and ladylike than the other.

171 ibid. I don't know if on this matter the perceptive minds of England will approve of what I've done. I do not intend to disapprove of what they do not condemn; and I further convene that following the principles of nature, virtue is always preferable to nobility and to wealth, but since in the Theatre I must reflect those customs upheld by common practice, they will forgive me for the necessity in which I found myself, to not offend the more largely approved tradition. 
della superbia hanno sconcertato il bellissimo ordine della natura. Questa madre comune ci considera tutti eguali, e l'alterigia dei grandi non si degna dei piccoli. Ma verrà un giorno, che dei piccoli e dei grandi si farà nuovamente tutta una pasta. $(\text { parte })^{172}$

There are also strong lines given to Bonfil (e.g. "Quanto cambierei volentieri questo gran palazzo con una delle vostre capanne!"173), in which the incompatibility of logic and rationality with imposed constraints of class division comes to the forefront:

Tutti amano Pamela, ed io non la dovrò amare? Ma il mio grado... Che grado? Sarò nato nobile, perché la nobiltà mi abbia a rendere sventurato? Pamela val più d'un regno, e se fossi un re, amerei Pamela più della mia corona. Ma l'amo tanto, ed ho cuor di lasciarla? Mi priverò della cosa più preziosa di questa terra? La cederò a mia sorella? Partirò per non più vederla? ${ }^{174}$

Also of note in this excerpt is the larmoyant quality of serio that colors these lines. In particular, the sequence of questions creates a feeling of restlessness, yearning, and again, the most powerful element of pathos: self-doubt. Gallarati has observed that, in opera, Goldoni further removes the more weighted monologues of his comedy (such as those above), though his conclusion, "Goldoni li considerava evidentemente incompatibili con la 'frivolezza' del teatro cantato" 175 is not

172 ibid.; Act III, iii. That one should die to save his honor, I understand; but that it be dishonorable to marry an honest girl because she is poor, I do not comprehend. I've heard it said many times that the world would be more beautiful if only men had not ruined it, men who, by reason of their arrogance, have upset the superb order of nature. This common mother considers us all equals, while the haughtiness of the greats disdains the common people. But there will come a day in which the great and the humble will once more become one mold. (exits)

173 ibid.; Act III, vi. How gladly I would exchange this great palazzo for one of your huts!

174 ibid., Act I, xii. Everyone loves Pamela, and I should not love her? But my rank... what rank? Was I born a nobleman so that my nobility could make me wretched? Pamela is worth more than a kingdom, and were I a King, I would love her more than my crown. I love her so, yet I have heart to leave her? Will I deprive myself of the most precious thing on this earth? Will I give her up to my sister? Depart to never see her again?

175 Paolo Gallarati, Musica e Maschera; 135. Goldoni evidently considered them incompatible with the 'frivolity' of opera theatre. 
entirely supported by Goldoni's operatic text. In particular, while in his dramma giocoso Goldoni does distance himself further from the original Pamela, Goldoni's libretto clearly maintains elements of moderated serio as above, largely responsible for the work's success. What is more, the many drammi giocosi examined through the course of this chapter (not to mention the close interconnection of opera theatre to comedy in La donna di governo) all testify that Goldoni hardly avoided taking a stance on social issues through his musical theatre. As we have seen in numerous libretti (Il filosofo di campagna, etc.) the life of commoners, in its closeness to nature, is often cited as a positive foil for corruption in the city, where, in the words of M.me Jevre, "gli uomini (...) per cagione della superbia hanno sconcertato il bellissimo ordine della natura" (men, by reason of their arrogance, have upset the beautiful order of nature).

First premiered in Parma in 1757 with music by Egidio Romualdo Duni, La buona figliuola became widely renowned in 1760 when it was given with a new musical setting by Niccolò Piccinni at the Teatro delle Dame in Rome, boasting thereafter a long itinerary throughout Europe, subsequently performed in Vienna, London, Madrid, Berlin, Stockholm, Copenhagen, Paris, and even young Philadelphia. Goldoni's derivation from La Pamela preserves an intermediate degree of fidelity to his source. While the author never includes close textual citation (nor any correspondence of name between characters) as we find in $L a$ donna di governo, he also does not create an altogether new plot as with Lo speziale. Instead, Goldoni maintains the same dynamics of relation between the central characters, preserving Pamela (now Cecchina, perhaps named after a character from an earlier dramma giocoso, La cascina), her Bonfil (the Marchese della Conchiglia), and his aristocratic and disapproving sister Lady Daure (the Marchesa Lucinda), yet also transposing the saga to an Italian setting, and most importantly diversifies the dramatic spectrum of the opera with new secondary characters. Entirely original additions include a lover of the Marchesa (serio) and an array of parti buffe: a maid, two farmers, and a foreign soldier. The most noteworthy aspect of this dramma giocoso remains its treatment of Cecchina and the Marchese as realistic mezzi caratteri, as seen previously. While the dramma giocoso presents significant departures from Goldoni's comedy, it remains an important milestone in psychological 
realism and moreover, in the creation of a new brand of serio that, attenuated, realistic, and freed from all Metastasian influence, is decidedly modern and will have a lasting influence beyond $18^{\text {th }}$ century Venice. Furthermore, the examples of direct translation cited above prove varying degrees of contact between Goldoni's comic theatre and his opera texts. Most of all, they testify to the author's efforts to improve comedy through realism by the progressive attenuation of stereotypical role divisions. Thanks to the foundations laid by our author, opera after Goldoni will be able to accomplish what Gallarati has called "la trasformazione del melodramma comico in una grande commedia musicale."176

\section{iii. Goldoni as musical reformer}

Goldoni's realist reform, undertaken at great cost in his prose theatre and reflected in his drammi giocosi, can be understood from many angles. The author's autobiographical remarks are filled with testimony of a changing horizon. From an initial desire to move beyond the masks of the Commedia dell'Arte, Goldoni's new style and a new comic practice set in motion a transformation of greater scope, which comes gradually into focus:

Nel primo e secondo anno di tale mio esercizio [as a comic author] non ho azzardata Commedia alcuna senza le Maschere, ma queste bensì a poco per volta sono andato rendendo men necessarie, facendo vedere al popolo che si poteva ridere senza di loro, e che anzi quella specie di riso, che viene dal frizzo nobile e spiritoso, è quella propria degl'omini di giudizio. ${ }^{177}$

176 Paolo Gallarati, Musica e Maschera; 136. The transformation of comic opera into great musical comedy.

177 Carlo Goldoni, Nona Lettera dell'Autore allo Stampatore dell'edizione Bettinelli di Venezia, 17501 52, riportato in Opere di Carlo Goldoni, a cura di Gianfranco Folena e Nicola Mangini, (Tomo VII a cura di Giovanni Getto) (Milano: Mursia, 1975); 1334. During my first two years as a playwright, I did not venture any comedy without Masks, but instead little by little I made these less necessary, showing audiences that they could laugh even without them, and moreover, that 
A comic theatre for a new, enlightened audience ("uomini di giudizio") is one capable of responding to the issues of its own time without the abstraction of masks or stereotyped characters. Beyond a question of style, Goldoni's realist reform necessarily acquires a higher implication, as it reflects the transformations of the social makeup, and captures the virtues and shortcomings of the modern lifestyle in all social contexts. Goldoni's reform comedies and drammi giocosi must also acknowledge current trends of thought, including rationalized Enlightenment messages of equality. Goldoni's reform of the spoken theatre is a thus double-sided coin, aiming at the renewal of theatrical custom and of social mores. While developing comedy without the Commedia dell'Arte mask and beyond the limits of superficial improvisation, Goldoni also makes his theatre the mirror of everyday life to exalt or deprecate its characters, a choice radically detached from the fantastical theatre of Carlo Gozzi, much in fashion in his day. Goldoni's contributions to the dramma giocoso must be evaluated according to this double achievement of ideological and formal renewal.

The ideological continuity between the majority of the drammi giocosi and the reform plays becomes apparent as Goldoni, following natural inclination, confronts the most widespread societal flaws in his libretti. Drammi giocosi and comedies alike are filled with positive and negative examples of every social condition, derived from firsthand observation (as the author deliberately reminds us). As the rigid barriers of tradition are dismantled, commoners, borghesi, and aristocratic characters display honesty, dishonesty, intelligence and foolishness.

We have also traced a number of recurring themes in Goldoni's opera theatre, including the contrast between Nature and civil corruption, between nobility of name and of deed, and the critique of rampant vices including excessive vanity, materialism, and fraud. Franco Fido's affirmation that the libretti are used more as ground for theatrical experimentation and farce ("scherzi e giochi di parole, paradossi e calembours, onomatopee e iperboli, equivoci e cacofonie plurilingui"'178)

laughter which is the product of noble and clever quip, is more befitting of a man of judgment.

178 Franco Fido, "Riforma e controriforma del teatro: I libretti per musica di Goldoni fra il 1748 e il 1753," in Studi Goldoniani vol. 7; 63. [Previously translated] 
than for real social commentary does not seem to fully correspond to the subjects and characters of the mature drammi giocosi. While certainly not excluding verbal or theatrical play, these works make sport of real moral problems and are able to integrate more serious tones with the prevailing comedy.

Ultimately, in prose comedy and opera theatre alike, even through the author's experimentation in many styles and settings, we may always reconnect his theatre to one unified intention:

Vorrei di buon cuore aver fatto e poter tuttavia fare con le Opere mie qualche frutto, indirizzando io tutti i miei pensieri non solamente a dilettare, che sarebbe piccolo pro, ma a far ancora qualche giovamento. ${ }^{179}$

In countless ways, in commentary as through direct practice, from his theatrical debut to his mature works, Goldoni underlines his conviction of the higher potential of comic theatre. It follows that the restitution of comedy's capacity of moral regulation hinges upon the level of realism attained within it. The psychological characterizations achieved in his mature libretti, therefore, unequivocally connect his drammi giocosi to these higher aims.

From the Metastasian serio of La scuola moderna to the emotional moderation and pathos of La buona figliuola, and the complete social disintegration of La donna di governo, we can clearly trace the trajectory of Goldoni's reform in music. The psychological characterizations that have contributed to the success of Goldoni's drammi giocosi are the end result of a gradual process that, beginning with the integration of serio within prevalently comic structures, continues towards the progressive attenuation of the divisions between buffo and serio, as testified by the realistic mezzo carattere. Moreover, the coexistence of buffo and

179 Carlo Goldoni, Ottava Lettera dell'Autore allo Stampatore dell'edizione Bettinelli di Venezia, 17501 52, riportato in Opere di Carlo Goldoni, a cura di Gianfranco Folena e Nicola Mangini, Tomo VII a cura di Giovanni Getto (Milano: Mursia, 1975); 1333. I hope that I have borne, and that I may continue to bear with my Works some fruit, as I have directed all my thoughts not only to the aim of giving pleasure, a small benefit, but indeed to being of some use. 
serio roles as a realistic device is further confirmed by the inclusion of moderated serio elements in his prose theatre as well.

From a formal point of view, Goldoni must be considered author of a number of structural innovations that most markedly characterized Classical opera throughout Europe in the later 18th century. First, the author modified the rigid succession of arias and recitative of Metastasian opera with the introduction of ariette. Unlike grand arias, these shorter pieces did not require the character to exit the scene, therefore creating more possibilities for plot development and musical variety. Goldoni further limited the use of static ariasby making frequent use of ensembles. Along these lines, another major innovation of Goldoni is the canonization of the ensemble finale, a practice that can be detected already in the intermezzi. The conclusion of L'amante cabala (1736) provides an excellent blueprint for the style of collective address that characterizes so many Classical works all the way to Mozart and Da Ponte: "Imparino tutti/ da sì bell'esempio/ che l'arte d'un empio/ trionfare non può." 180 Importantly, in the mature drammi giocosi, ensemble pieces surpass the chorale function exemplified above to acquire an increasingly polyphonic dimension. No longer static, they serve as vehicles for the advancement of the action, rendering opera theatre more lifelike and dynamic.

Many of these innovations, especially the integration of serio with buffo and the use of ensembles within scenes, are absolute and unique to Goldoni. The chapter that follows is dedicated to his musical legacy, to make clear the extent to which these features shaped comic opera throughout the century in the best European schools. In Mozart's operas and the prestigious Austrian tradition, for example, the entire catalog of Goldoni's dramatic effects can be found in full form. It is important not to overlook these relevant innovations in order to understand the stature of this playwright in his own time, and in our musical tradition.

180 Carlo Goldoni, L'Amante Cabala; Act II, scena ultima. Let all learn/ from this example/ that the art of a villain/ can never prevail. 


\section{Goldoni's Musical Legacy}

Between 1749 and 1761, Venetian theatres produced a total of 69 new comic operas. ${ }^{181}$ Of these, 44 used libretti by Carlo Goldoni. After he left Venice, Goldoni's drammi giocosi continued to receive performance every year until 1768. Over the entire arc of the 18th century, an estimate of nearly 2000 comic operas were produced in all of Italy, of which 283 productions with our author's texts. Goldoni's texts began to circulate outside of Italy as early as the 1749 , launching the dramma giocoso throughout the whole of Europe.

Within his own lifetime, Goldoni's publication history provides further testimony of the wide circulation of his work. In the preface to the Pasquali edition (one of the last undertaken during his life), Goldoni offers this modest summary:

Ecco dunque alla luce del mondo il primo tomo della nuova edizione delle mie Commedie, ed eccolo a fronte di altre dieci edizioni che lo hanno fin'or prevenuto, ed hanno, posso dir senza ostentazione, empito il mondo delle Opere mie (...) Cinque edizioni del Bettinelli, una del Pitteri in Venezia, la mia di Firenze, quantunque spacciata prima di terminarla; le ristampe di Pesaro, di Torino, di Napoli, di Bologna; le traduzioni in Francese, in Inglese, in Tedesco(...) etc. ${ }^{182}$

Goldoni's comedies and drammi giocosi boast an impressive reach. The vast diffusion of these works has in large part been traced and catalogued

181 As accounted for by by E. Dent \& P. Smith, "The Italian libretto to 1800 " in New Grove Dictionary of Music and Musicians, 14th Edition, vol. 13. (New York: Macmillan Press, 1995).

182 Carlo Goldoni, Memorie Italiane (Prefazioni ai Diciassette Tomi delle Commedie edite a Venezia da G.B. Pasquali), tomo I. Here then, brought to the light of the world, is the first volume of the new edition of my Comedies, at the head of ten other editions that have preceded it, and have, I can say without boasting, filled the world with my Works (...) Five editions by Bettinelli, one by Pitteri in Venice, my own in Florence, however doomed it was before I even finished it; then reprinting in Pesaro, Torino, Naples, and Bologna; not counting the translations into French, English, German, (...) etc. 
in the latest critical edition of Goldoni's complete works (directed by Anna Laura Bellina and Anna Vencato). ${ }^{183}$

\section{i. Globalization? Old news! International drammi giocosi and diffusion of a new genre}

The exportation of Goldoni's texts for music began from his intermezzi. While the earliest of these did not appear outside of Italy, Il filosofo (1735) was performed at the royal theatre in Potsdam set to music by Johann Friedrich Agricola (17201 1774), who also translated the libretto into German. Agricola's musical setting has been traced from Prague (1752) to the electoral court of Mannheim (1753), Bonn (1757), Dresden (1762), and a new appearance at Mannheim as late as 1771. Similar itineraries were made by L'amor fa l'uomo cieco (Hamburg 1743, Leipzig 1744, Prague 1744) and Il finto pazzo (Dresden 1747, Vienna 1759, Prague 1748). An even longer trail was left by the popular La favola dei tre gobbi (1749), which from Venice traveled to Verona and Padua (1750), Ferrara (1756), Parma (1773, performed for Duke Ferdinando di Borbone), and Naples (1783) in the original musical setting of Neapolitan 1 trained composer Vincenzo Ciampi. Outside of Italy, the intermezzo saw performances in Potsdam (1754), Munich (1758), Vienna (1759), Prague (1760), Bonn (1764), Brussels (1766), Saint Petersburg (1759), and even appearing in French (Les trois bossus) and Slavic (Tri brata gorbuni) translations.

The paths of Goldoni's early works foreshadow the diffusion of his drammi giocosi, which come to overwhelming numbers in their appearances throughout Europe. The first dramma giocoso to appear outside of Italy was Il negligente, given in London in 1749 and 1750. It was followed by Il mondo della luna, given in Barcellona (1751, 1765), Brussels (1753), Dresden (1754), Prague (1755), Hamburg (1755),

183 Edizione Nazionale delle opere di Carlo Goldoni (Venezia: Marsilio, 2009present). 
Saint Petersburg (1758), Brunswick (1760), London (1760, 1761), Brno (1761), and many others. Virtually all of Goldoni's principal libretti traveled throughout Europe; even the lesser-known La scuola moderna appeared in Berlin and in Paris by 1754.

Beyond the original works, we must especially take into account foreign translations and the manifold musical settings undertaken by composers of many nations. The list of composers who set Goldoni's libretti (often several) to music is almost as endless as the chronology of their performances. Outside of Italy, these include Florian Gassmann (1729-1774) in Presburg, Pedro Avondano (1714-1782) in Lisbon, Venanzio Rauzzini (1746-1810) in Munich, Carl Dittersdorf (1739-1799) and Franz Joseph Haydn (1732-1809) in Esterhaza, Antonio Salieri (1750-1825) in Vienna, and finally the young W. A. Mozart (1756-1791) among many others. The great variety of musical adaptations created implies the gradual assimilation of Goldoni's theatrical innovations within the traditions of other national schools, accounting for their reappearance in the works of Mozart and Da Ponte among others. Naturally, a great number of musical reworkings was produced in Italy as well, and these too traveled beyond the Alps as far as Russia, particularly the scores of Domenico Cimarosa (1749-1801), Giovanni Paisiello (1740-1816), and Niccolò Piccinni (1728-1800).

Goldoni's works did not travel exclusively through the exportation of texts, but also thanks to a thriving network of cultural exchange that characterized the entire 18th1 century, marking in this sense the beginning of the modern era. To cite a rather extreme example, we know that Lorenzo da Ponte traveled the whole of Europe, from then-Austrian Gorizia to Dresden, Vienna (where he collaborated with Salieri), Prague (where he met Giacomo Casanova, another such adventurous figure), then London, and, fleeing financial disaster, finally to New York city, where as a naturalized American he became the first professor of Italian at Columbia University.

In the same way (though for more honorable reasons), several of Goldoni's direct collaborators traveled extensively (as the author himself did, throughout Italy), becoming conduits of Goldoni's texts. Baldassarre Galuppi, for example, one of Goldoni's regular composers who first set to music L'Arcadia in Brenta, Il Conte Caramella, and Arcifanfano re dei matti (for the Teatro S. Angelo, Accademia Vecchia 
in Verona, and the Teatro S. Moisè respectively), and following their success Il mondo della luna, Il paese della cuccagna, Il mondo alla rovescia ossia Le donne che comandano, Il filosofo di campagna (considered his masterpiece), Le virtuose ridicole and Le pescatrici in a collaboration that lasted until 1756, acquired such fame that he was called to Saint Petersburg by Catherine II, where he served as maestro di cappella at her court. Goldoni's drammi giocosi received an additional impulse in Russia thanks to the Florentine composer Giovanni Rutini (1723-1797), who, during a tour with Locatelli, proposed his own settings of Goldoni texts. Another of Goldoni's composers to travel far was Giuseppe Scolari, who died in Lisbon, where many of the surviving musical manuscripts on Goldoni's texts are still housed today.

Goldoni's works were performed outside of Venice throughout his career, but began to circulate in northern Europe especially after his move to Paris in 1761. During his voyage to the city of Molière, Goldoni fell ill and was required to delay his arrival. While convalescing in Bologna, he authored a peculiar dramma giocoso, La bella verità (The Pretty Truth), for his patron and frequent correspondent the Marquis Albergati. Clearly Goldoni knew it was not his best work: "Arrivé à Bologne, je tombai malade; on me fit faire par force une Opéra Comique; l'ouvrage sentoit le fièvre comme moi."'184 The result was a peculiar metatheatrical work about the absurdities of show business, ${ }^{185}$ in which Goldoni even represents himself- through the anagrammed character Loran Glodoci- as a miserable librettist subject to the demands and whim of his vocalists and actors. For its very subject matter if nothing else, this text clearly adheres to the realist tradition that Goldoni hoped to develop with more freedom at the Comédie Italienne once in Paris. He also deliberately omits any ties to a specific setting, which, coupled

184 Carlo Goldoni, Memoires, vol. II, xlvi. Once I arrived in Bologna, I fell ill; they forced me to write a comic opera; the work felt the fever as much as I did.

185 Comic criticism of theatre was a very diffuse in the 18th century, beginning early on with Benedetto Marcello's popular satire, Il Teatro alla Moda (1720). Goldoni's is thus one small tile in a longstanding tradition, and by no means his only metatheatrical work, at that. Other examples include: Il teatro comico (1750), La cameriera brillante (The Brilliant Chambermaid, 1754), and in musical theatre L'Arcadia in Brenta (1949), the farce La cantarina (The Singer, 1756), and through the character of Petronilla, La ritornata di Londra (1756). 
with a rather generic, Italianate language, shows a deliberate effort to transcend the Venetian context and point towards a broader, more diversified, European stage.

In keeping with this new international perspective, the libretti Goldoni wrote once in Paris (five over a period of five years, 1763-68, and three between 1777-79) were almost all derived from contemporary literary models of non-Italian authors. Galuppi's Il re alla caccia (1763, premiered at the Teatro S. Samuele), for example, can be tied to La partie de chasse d'Henri IV (The Hunting Match of King Henry IV, 1762), a French comedy by Charles Collé, as well as to the French opéra comique drawn from it, Le roi et le fermier (The King and the Farmer) libretto by Michel-Jean Sedaine, of which Goldoni recalls:

Je vus le Roi et le Fermier à sa première représentation, j'en fus extrêmement content, et je le voyois avec douleur prêt a tomber, il se releva peu-à- peu, on lui rendit justice; il eut un nombre infini de représentations, et on le voit encore avec plaisir. $^{186}$

Il re alla caccia was followed by La finta semplice (1764, premiered at the Teatro $S$. Moisè on a score by Perillo (dates unknown), now lost), based on La fausse agnès ou le poète campagnard, prose comedy in three acts by Destouches (translated by the Marchesa Ottoboni, a friend of Giuseppe Parini, with the title I poeti in villa). La notte critica (The Critical Night, 1766, for the Teatro S. Cassiano, set by Boroni (?- 1792)) is based on a French scénario by Goldoni, Les rendezvous nocturnes (Nighttime Encounters), and the first group concludes with L'astuzia felice (The Happy [successful] Guile) 1767, originally titled La cameriera spiritosa (The Spirited Maid) for its premiere in Milan, 1766, on a score by Gherardeschi (dates unknown), now lost) and Le nozze in campagna (The Country Wedding, 1768, for the Teatro S. Moisè, on a score by Gregorio Sciroli (1722-1781), also lost).

Importantly, these first Parisian drammi giocosi were still written for Italian audiences, and most had Venetian premieres; this because

186 Carlo Goldoni, Memoires; II, xv. I saw The King and the Farmer at its premiere, I liked it very much, and I was pained to see it on the verge of failure, but it recovered little by little, and in the end was given justice; the work received an infinite number of productions, and it is still viewed with pleasure. 
Goldoni's initial intent was to remain in France only for a limited period, and these collaborations were meant to preserve his name at home and maintain professional grounds for a return to Venice. These libretti therefore do not present significant departures from Goldoni's new consolidated style, new mode of realism, and structural complexity in ensembles. They are texts that evidence new horizons but also important elements of continuity with the author's Venetian output.

Differences arise in Goldoni's final three libretti, no longer written for Venetian theatre and of diverse nature: while Vittorina (1777) is still a dramma giocoso (or "new comic opera," as it was called in London for its world premiere at the King's Theatre, composer unknown), I volponi (The Old Foxes, composer unknown) of the same year, premiered in Paris, is a simple dramma per musica, while Il talismano (The Talisman, 1779, premiered at the Teatro Canobiana in Milan) is instead a commedia per musica. Of the three texts, only the first appears to retain some continuity with Goldoni's preceding realistic tradition, by no coincidence the only named dramma giocoso of the three. In particular, Vittorina suggests clear points of contact with $L a$ buona figliuola, a story well known to Parisian audiences. By contrast, I volponi is surprisingly general in content, without a definite setting (Goldoni's only indication is "nel castello del Marchese"), and even without specific names for some of the characters (the "Marchese," for example, is known only by title). The characters in this work, contrary to Goldoni's norm, are not well-developed originals but rather typified exponents of different trades and social spheres, as Franco Fido has observed. ${ }^{187}$ In equal measure, Il talismano is largely occupied with exoticism rather than realism, set in a feud in an unspecified time, involving gypsies and mystical elements of their world, including palm readings and a famous talisman that changes its holder's appearance. Despite the popularity of fantastical theatre at the time, Goldoni's talisman does not detain any true supernatural power, yet at the same time he does not criticize this illusion as elsewhere he appeared ready to. It is just one among many adventurous elements,

187 F. Fido, Nuova Guida al Goldoni (Torino: Einaudi, 2000); 150. 
including the recovery of a daughter lost at sea, that focus the work on extraordinary rather than quotidian events.

Judging from these very last works, Goldoni's career appears to close in an enigmatic retrocession from the hallmark characteristics of his drammi giocosi and the dilution of their realistic elements, and an analogous- or perhaps even more burdensome- surrender of the reform principles also occurs in Goldoni's prose theatre during this time. And yet, while an inversion from decades of innovative work may seem strange, the author's broader circumstances are the clear cause.

Goldoni was called to Paris to renew public interest in the Comédie Italienne, of which he was named director, an offer he accepted with optimism but, at the same time, undeniably motivated by disappointments, too. His theatrical reform had Venice did not come without cost, and Goldoni was tried by his rivals Carlo Gozzi and Pietro Chiari, the demands of his impresari, and the protests of actors who accustomed to the freedom of the Commedia dell'Arte. Paris on the other hand seemed to offer better treatment, not only materially but ideologically: Goldoni was a great admirer of Molière, with whom he shared the inclination for social criticism and realism, ${ }^{188}$ and on more than one occasion had received the praises of Voltaire for his theatre.

He set out for Paris not without a certain sadness, as testified by his autobiographical farewell play Una delle ultime sere di carnovale, but with high hopes of finding a new audience and new collaborators more open to his ideas, and while early letters show enthusiasm and satisfaction for the distinguished treatment received, so different from what he had left behind: "Che ne dite, eh? Bella differenza! Dover faticare come un cane per guadagnare cento ducati, amareggiati ancora da rimproveri e malegrazie!" 189 As early as the next year, however, problems began to arise as Goldoni suspected Denis Diderot of plagiarizing his

188 In the words of Giorgio Padoan "L'attenzione di Goldoni a Molière si lega concretamente all'attuazione della riforma." Giorgio Padoan, in Carlo Goldoni, 1793- 1993. Atti del Convegno dei Bicentenario (Venezia: Regione del Veneto, 1995); 24.

189 Al Sig. Gabriele Cornet" (Paris, Sept. 27, 1762), from Lettere di Carlo Goldoni, ed. by Ernesto Masi (Bologna: Zanichelli); 175. What do you say, eh? A nice difference! To have to work like a dog to earn a hundred ducats, and on top of that embittered by reproofs and ingratitude. 
Il vero amico (The True Friend, 1750) in the creation of Le fils naturel (The Natural Child, 1757), a diatribe some scholars suggest may have contributed to the relative indifference accorded to Goldoni's reform project in France. ${ }^{190}$

Whatever the reason, it soon became apparent that Goldoni's work in Paris presented no fewer challenges than his previous charges in Venice. Not only was the Comédie Italienne incorporated within the Opéra comique, contributing to its crisis, but moreover Goldoni soon discovered that the preferences of Parisian audiences, not to mention of his new performers, did not go beyond the Commedia dell'Arte he had so labored to leave behind. Roberta Turchi's description of Goldoni's condition as one of "disagio culturale e esistenziale," 191 is perhaps no understatement to judge from his later correspondence: "Questi commedianti italiani sono des parasseux... Il paese sempre più mi diletta. Ma il diletto senza l'utile non è per un uomo, che ha bisogno dell'uno e dell'altro."'192

Little more than one year after his arrival Goldoni could already declare with certainty: "Il gusto delle buone commedie in questo paese è finito. Fa pietà il Teatro moderno francese: non si bada più alla condotta, ai caratteri, alla verità." ${ }^{193}$ A further element of disenchantment followed in the treatment given to Goldoni's comedies at court, where they were "scannate in tre quarti d'ora" because "il Re voleva andare al soupé" (slaughtered in three quarters of an hour, as the King wanted to go to supper). As Roberta Turchi rightly observes, "Il destino toccato a

190 See Paola Luciani, Drammaturgie goldoniane, (Firenze: Società Editrice Fiorentina, 2012).

191 Roberta Turchi, "Un'edizione 'colta e magnifica,'” introduzione a Carlo Goldoni, Memorie Italiane, III (Venezia: Marsilio, 2008); 23. cultural and existential unease.

192 ibid “Al Marchese Albergati Capacelli" (Paris, Dec. 13, 1762) from Lettere di Carlo Goldoni, ed. by Ernesto Masi (Bologna: Zanichelli); 188. These Italian actors are lazy...this country entertains me every day more. But pleasure without usefulness is not for a man, who has need of one and the other.

193 Lettera al Marchese Albergati Capacelli (13 June 1763) in Tutte le opere di Carlo Goldoni, vol. XIVa cura di G. Ortolani (Milano: Mondadori, 19351 43); 287. The good taste in comedy of this Country is finished. Modern French theatre is pitiful: there is no attention to plot, to the characters, and to truth [realism]. 
corte alle sue commedie segnò la fine del convincimento, legato al mito di Luigi XIV, che gli uomini di lettere godessero in Francia di favori maggiori che in Italia." ${ }^{194}$ Despite some modest successes in theatre, therefore, in 1765 Goldoni officially resigned his post at the Comédie Italienne, becoming the official Italian language tutor at the court of Louis XV (his pupils Madame Adelaide, the king's firstborn daughter, and Marie Joseph of Saxony learned Italian with the help of his texts), following the entourage from Paris to Versailles. Goldoni lived through the French revolution, during which his court stipend was, of course, suspended. Troubled by debt and outliving his fame, the author died in Paris in 1793, just as his income was being reinstated. In northern Europe, however, Goldoni's works lived on to make a lasting imprint.

\section{ii. Mozart and Goldoni}

Generations after Goldoni, it is possible to find echoes of his celebrated texts in the works of many. Il maestro di cappella (1793, first performed in Berlin) of Domenico Cimarosa (1749-1801, librettist in this case unknown), for example, uses verses taken directly from Goldoni's dramma giocoso, Il viaggiatore ridicolo (1757):

Ci sposeremo fra suoni e canti Sposi brillanti, pieni d'amor. Voglio i violini, voglio i violoni, Voglio il fagotto, con l'oboè [suonano corni da caccia] questo strumento non fa per me. ${ }^{195}$

194 Roberta Turchi, "Un'edizione 'colta e magnifica," introduzione a Carlo Goldoni, Memorie Italiane, III (Venezia: Marsilio, 2008); 25. The fate met by his comedies at court marked the end of the belief, tied to the legacy of Louis XIV, that men of letters could enjoy more favorable treatment in France than in Italy.

195 Carlo Goldoni, Il viaggiatore ridicolo; Act III, iii. We will be wed amidst music and song, shining newlyweds, brimming with love. I want violins, and want violas [and celli], I want bassoon with oboe [hunting horns are heard]. No, this instrument doesn't suit me! 
The musical use of the horn to signify "cornuto" (cuckold) is a comic device used by Mozart as well, in Figaro's aria "Aprite un po' quegli occhi" (Le Nozze di Figaro, Act IV, viii). More famously, Da Ponte's Don Giovanni appears to quote various Goldoni texts. Most notably, the character of Semplicina in Arcifanfano re dei matti first utters the verses "vorrei e non vorrei...son fra il si e il no,"196 the hallmark of Zerlina's role in Mozart's famous duet, "Là ci darem la mano" (Don Giovanni I, iii). Goldoni's Il viaggiatore ridicolo, known throughout Europe by 1770, also contains a 'catalogue aria' that, while in comic key, bears notable similarities to Leporello's analogous exploit:

A Lion la Contessa la Cra. A Paris la Marchesa la Gru. A Madrid la Duchessa del Bos. In Inghilterra Miledi la Stos. In Germania ho le mie Baronesse. In Italia le mie Principesse...etc. ${ }^{197}$

Lorenzo da Ponte (1749-1838), together with Giambattista Casti (1724-1803), was one of the most prominent librettists to continue in Goldoni's style, though his theatre was also imitated by Marco Coltellini (1719-1777), author of opera seria libretti for Gluck, Traetta, and others, and by Giovanni Bertati (1735-1815), the most prolific librettist to follow Goldoni, best known for Cimarosa's Il matrimonio segreto (The Secret Wedding, 1792).

In the case of Don Giovanni, notwithstanding Tirso de Molina's original text, Moliere's Le festin de pierre (1665), and Goldoni's own Don Giovanni Tenorio o sia il dissoluto (1736), the direct model used by Da Ponte was most likely Don Giovanni o sia Il convitato di pietra (The Stone Guest), libretto in one Act dated 1787 by Bertati. Notably, Bertati became one of the most sought-after librettists in Venice after Goldoni's departure. His texts therefore drew from the same context that Goldoni had helped to create and establish before leaving. The music

196 Carlo Goldoni, Arcifanfano Re dei matti,; Act II, viii. I'd like to and I wouldn't... I'm between yes and no.

197 Carlo Goldoni, Il viaggiatore ridicolo, Act II, iv. In Lyon the Countess of Crow. In Paris the Marchesa of Stork. In Madrid the Duchess of Bos. In England Mylady of Stos. In Germany I have my baronesses. In Italy my princesses (...). 
for Bertati's rendition was by Giuseppe Gazzaniga, and some scholars have furthermore seen direct influences in Mozart's score. ${ }^{198}$

A further bridge of connection from Goldoni to Emanuele Conegliano- better known by his pen name Lorenzo da Ponte- is the figure of Casti, author of $l l$ Re Teodoro in Venezia drawn from Chapter XXVI of Voltaire's Candide. For Paolo Gallarati, Casti is a point of transition from the net divisions of buffo and serio of the 'rationalistic' Goldoni to the entirely realistic and psychologically-oriented Mozartian theatre, ${ }^{199}$ though the attenuation of buffo and serio in opera clearly already commences in Goldoni's later drammi giocosi, especially through the mezzo carattere and new elements of sentimentalism as we have seen. Casti definitively abolishes the sententious Metastasian style of arias as well as caricature or satirical humor in the comic sphere, and as the following description of his own work shows, he contributes to the continuation of Goldoni's desire for realism through a different approach:

(...)dieci o dodici drammi eroicomici di genere affatto nuovo, ove trattandosi temi e soggetti seri, eroici, tragici, vi si trappongono dei tratti comici ove la circostanza della cosa o delle persone lo richiede, seguendo in ciò la natura stessa. ${ }^{200}$

While Casti also continued Goldoni's legacy of expanding ensemble pieces and using them more frequently, he did not emulate Goldoni in every respect, as his title of "drammi eroicomici" shows. Furthermore, in a spirit of affinity with tragic theatre, he often included dramatized prologues ("esposizione dell'argomento") to his operas in the manner of Metastasio. It was the cultivated medietas of Casti's theatre that assured his fame, but also brought criticism from Da Ponte:

198 D. Heartz, "Goldoni, Don Giovanni, and the dramma giocoso" (Musical Times n. 1642, 1979).

199 Paolo Gallarati, Musica e Maschera. "Tutto volge verso una medietas che neutralizza il divario tra personaggi seri e comici e tende a fare di ciascuno un carattere individuale."

[Everything turns towards a medietas that neutralizes the divarication between tragic and comic roles, and tends to make each an original character.]

200 G. B. Casti, Lettera (20 July 1796) cited in Paolo Gallarati; 157. (...) ten or twelve drammi eroicomici of a new genre, where, dealing with subjects that are serious, heroic, and tragic, we juxtapose some comic elements where the circumstances of the action or the characters requires, following Nature herself. 
Non vi mancava purità di lingua, non vaghezza di stile, non grazie e armonia di verso, non sali, non eleganza, non brio; le arie erano bellissime, i pezzi concertati deliziosi, i finali molto poetici; eppure il dramma non era né caldo, né interessante, né comico, né teatrale. L'azione era languida, i caratteri insipidi, la catastrofe inverisimile e quasi tragica. Le parti insomma erano ottime, ma il tutto era un mostro. Mi parve di veder un gioielliere, che guasta l'effetto di molte pietre preziose per non saper bene legarle e disporle con ordine e simmetria. (...) Non osai tuttavia dire ad alcuno il pensiero mio, certissime essendo che, se fatto l'avessi, m'avrebbero lapidato o messo come farnetico ai' pazzerelli. Casti era più infallibile a Vienna che il papa a Roma. ${ }^{201}$

It is not surprising that Da Ponte, to a greater extent than Casti, in his libretti preserves Goldoni's structure of buffi, seri, and mezzi caratteri in psychological characterization, and inserts serio material within an overarching structure of comedy.

In Mozart's collaboration with da Ponte, both structural and ideological elements of Goldoni's drammi giocosi are found in abundance. Even before his work with the Veneto librettist, however, Mozart had become acquainted with Goldoni's libretti through direct experience. His first opera La finta semplice (The False Simpleton, 1768), written when he was 12 years old, was based on a reworking of Goldoni's dramma giocoso of the same title (1764) by Marco Coltellini, then court poet in Vienna. Four years later, Mozart also produced La finta giardiniera (The False Gardener), which, despite its lack of attribution to an author, Daniel Heartz has connected to La buona figliuola. ${ }^{202}$

By the time Mozart began setting operatic texts, the spectrum of dramatic roles developed by Goldoni through a lifetime of innovation

201 Lorenzo da Ponte, Memorie, I, ii. It was not without purity of language, nor without beauty of style, nor spirit, nor elegance, nor verve; the arias were very beautiful, the ensemble pieces delightful, and the finali very poetic; and yet the dramma did not have warmth, nor was it interesting, nor comic, nor theatrical. The action was languid, the characters insipid, the action unrealistic and almost tragic. The parts were very good, yet the whole was a monster. It was like seeing a jeweler who ruins the effect of many precious gems because he does not know how to order them in symmetry. (...) I nonetheless did not dare to share my thoughts with anyone, because, had I done so, they would have stoned me or thrown me into the asylum. Casti was more infallible in Vienna than the Pope in Rome.

202 D. Heartz, Mozart's Operas (Berkeley: University of California Press, 1990); 199. "(...) an anonymous and clumsy offspring of La Buona Figliuola." 
had become common practice, or in the words of Da Ponte, "domma teatrale." One element among many that surfaces in Da Ponte's autobiography is the consolidation of the ensemble finale as a standard practice, though this did not meet with particular enthusiasm on the part of the librettist:

In questo finale devono per teatrale domma comparire in scena tutti i cantanti, se fosser trecento, a uno, a due, a tre, a sei, a dieci, a sessanta, per cantarvi dei' soli, de' duetti, de' terzetti, de' sestetti, de' sessantetti; e se l'intreccio del dramma nol permette, bisogna che il poeta trovi la strada di farselo permettere, a dispetto del criterio, della ragione e di tutti gli Aristotili della terra; e, se trovasi poi che va male, tanto peggio per lui. ${ }^{203}$

Da Ponte, and of course Mozart with him, thereby follows the trajectory of Goldoni and Casti in the expansion of the ensemble finale, which in his theatre becomes "una spezie di commediola o di picciol dramma da sé, e richiede un novello intreccio ed un interesse straordinario." 204

Goldoni's legacy was thereby clearly assimilated by both da Ponte and Mozart himself, who, as we saw previously, makes clear distinction between parti buffe, parti serie, and mezzi caratteri in his personal letters:

(...) das nothwendigste dabeÿ aber ist recht Comisch im ganzen - und wen es dan möglich wäre 2 gleich gute frauenzimer Rollen hinein zu bringen. - die eine müsste Seria, die andere aber Mezzo Carattere seÿn - aber an güte - müssten beÿde Rollen ganz gleich seÿn. - das dritte frauenzimer kan aber ganz Buffa seÿn. ${ }^{205}$

Looking ahead to the first installment of the Mozart- Da Ponte trilogy, Le nozze di Figaro (1786), we encounter a markedly conversational brand of Italian, and strategic use of extended musical numbers; in

203 ibid.; 147-48; In this finale, theatrical practice dictates that all singers should appear on the stage, be they one, two, three, six, ten, or sixty, to sing soli, duets, trios, sextets, or sixtyets; and if the plot does not permit it, the poet must find a way to make it possible, despite his scruples, reason, and all the Aristotles of this Earth; and, if he were to discover that it not go well, too bad for him.

204 ibid.; I, ii (...) a sort of small comedy or drama unto itself, requiring a new plot and extraordinary appeal.

205 W. A. Mozart, letter to L. Mozart (7 May, 1783). [previously translated] 
fact, of its 28 total musical numbers, only half are arias and the rest ensembles, large or small. Naturally, the opera carries strong ideological implications (so much so that Beaumarchais' original source text, La folle journée (The Crazy Day), 1778 initially met with censure), and most importantly balances comedy and sentimental introspection around two pivotal mezzi caratteri; it would be difficult to image a work more fully in resonance with the intentions of Carlo Goldoni.

A realistic element of particular strength in Mozart's 'Italian' operas is the fragmentation of dialogue in recitative, which from Goldoni's example Da Ponte is carried to an extreme level of concision. Da Ponte's aria texts for Mozart are then often in free form, adding to their natural, non-theatrical quality, and as a general characteristic, Mozart contributes further realism in the musical sphere through the dramatic acceleration of his arias, such that a long page of text may be consumed in a short span of time.

Naturally, the admiration of later centuries for Mozart's works also stems, and in large part, from the total fusion of music and text that the he is able to achieve with spontaneity. Yet this concept too, the search for intimate connection between word and music, is a legacy of Goldoni's generation. While Goldoni was making his stand for realism in theatre, others in Venice were pursuing the same principles for music, even if this art, by nature, is the most abstract. Superficiality was criticized in music as well as in comedy, and the suggested remedies were rationality, and realism.

This according to the Venetian essayist, philosopher, and uomo di mondo Francesco Algarotti (1712-1764) in his Saggio Sopra l'Opera in Musica (Essay on Musical Operas, 1755), published just a few years after Goldoni's Conte Caramella. The complaints he voices are numerous, and often not dissimilar from the issues confronted so ironically in Benedetto Marcello's own satirical pamphlet. Algarotti however goes a step further to discuss musical settings in their own right,

Blandire in ogni modo le orecchie, allettarle, sorprenderle, è il primo pensiero degli odierni compositori; non muovere il cuore, o scaldar l'immaginativa di chi ascolta $(\ldots)$ 
even as concerns exclusively instrumental sections such as the opening sinfonia:

Ma oggidì viene considerata la sinfonia, come cosa distaccata in tutto e diversa dal Dramma, come una strombazzata, diciam così, con che si abbiano a riempiere d'avanzo, e ad intronare gli orecchi dell'udienza. ${ }^{206}$

Although not an esteemer of comic opera, interestingly Algarotti could but exempt this genre from his heavier criticisms:

Non è però che una qualche immagine di verità non si scorga anche a' dì nostri nella musica. Ne sono in esempio singolarmente gl'Intermezzi, e le Operette buffe (altrove chiamate opere buffe), ove la qualità principalissima dell'espressione domina assai meglio, che in qualunque altro componimento che sia. ${ }^{207}$

Comic opera would appear to have an intrisic advantage in the measure of verisimilitude. For an uncompromising Algarotti this 'virtue' would appear to stem only from the necessity to avoid overburdening the "cantanti mediocrissimi" (worse than mediocre singers) relegated to comic operas, spurring composers to inevitably keep it simple in their scores. Needless to say a less than flattering interpretation, but one not supported by the difficulty of certain vocal parts from this repertoire, nor by the documented involvement of professional singers of good reputation 'borrowed' from opera seria, such as the famous castrato Salvatore Consorti. The crucial point, in any event, is that comic opera "vuol assecondar la natura" (wants to support what is natural), and in this lies the key to its success: "a cagione appunto della verità che in se

206 Francesco Algarotti, Saggio Sopra l'Opera in Musica, 1755 \& 1763 editions, curated by Annalisa Bini, Libreria Musicale Italiana, 1989; 26. The primary concern of today's composers is to entice, flatter, and surprise the ear by any means possible; not to warm the heart or move the imagination of the listener (...) Nowadays the sinfonia is seen as something different, and completely detached, from the Dramma, like some sort of fanfare, let's call it that, whose purpose is to daze and saturate the audience's ears from the start.

207 ibid., 38. Yet it can't be said that some image of truth not be found in today's music. Unique examples of this are the Intermezzi and Operette buffe (elsewhere called Opere Buffe), in which natural quality of expression dominates much more clearly than in any other type of composition... 
contiene, [l'opera buffa] ha la voga e trionfa, etc." (by reason of the truth is contains, it is in fashion and is winning out).

If for music too, the auspice is to find a close, natural connection to the plot it serves to convey, clearly Goldoni's mezzo carattere and his sentimental dimension, in addition to enriching the action onstage, also aids the diversification of musical content. The scores themselves confirm how Cecchina, or Count Caramella, or King Henry IV, or Mozart's Don Giovanni, for that matter, are able to transition seamlessly from a comic cavatina to a serio or sentimental aria within a brief span of stage time.

Mozart's Don Giovanni (1787), furthermore, is the sole of his operas to bear the title of dramma giocoso (and not opera buffa), in which 'dramma' appears as a clear link to opera seria and tragedy. As requested in Mozart's letter, this opera features three prime donne, a full serio (Donna Anna), a sentimental mezzo carattere (Donna Elvira), and a $b u f f a$, Zerlina. While not entirely realistic because of its necessary dependence upon the picaresque legend of Don Juan, and most notably its supernatural retrieval of the Commendatore from the grave, this dramma giocoso demonstrates the surprising depth and darkness that this prevalently comic genre can support.

\section{iii. Conclusions}

Goldoni's contributions to the evolution of musical theatre are of both technical and ideological nature. His many structural innovations, such as the use of ariette instead of static exit arias, duets and ensembles at the beginning of and within scenes, and the collective ensemble finale, diversify the means of conveying the plot and ideology of his works. In terms of content, the social types and societal customs that Goldoni examines and playfully criticizes are universal. Nobility is ridiculed but so too are commoners too attached to wealth. Even the industrious bourgeoisie, when at fault, is denounced. The power of Goldoni's social commentary stems from the relevance and timeliness of his depictions, 
and his adherence to figures and styles (dialects, for example, and discursiveness) of daily life.

Most importantly, the combination of serio and buffo elements in the dramma giocoso, and the progressive attenuation of the boundaries between them, represents the highest outcome of the author's search for realism, and a significant point of contact with his reform of the prose theatre. With the lifelike representation of comic characters, tragic foils, and mezzi caratteri in the dramma giocoso, Goldoni casts buffo and serio into coexistence, creating a new, realistic opera theatre that responds to its own time and continues well beyond it in its relevance.

Ultimately, reaching well beyond his own vast production, Goldoni's musical innovations form the foundations of the fully evolved dramma giocoso of the Viennese school. The highest achievements of Mozart and Da Ponte are emblematic of Goldoni's innovations and how, perfected at the end of the 18th century, these became canonical and enduring.

From its complex origins to its most sophisticated, psychological forms, this theatrical genre develops in a philosophy of realism and social relevance. Goldoni's influence on this type of musical representation has not been fully considered, and much remains to be discovered, but his determining contributions to the dramma giocoso, before him only nascent, after him an international genre, cannot be overstated and warrant significant reappraisal in the study of music history. 
Pervinca Rista - 978-3-0343-3564-5

Downloaded from PubFactory at 01/11/2019 02:35:03AM

via free access 


\section{Varia Musicologica}

Band 1 Mine Doğantan

Mathis Lussy - A Pioneer in Studies of Expressive

Performance

188 S. 2002.

ISBN 3-906769-50-X / US-ISBN 0-8204-5897-X

Band 2 Kristina Ericson

Heinz Holliger - Spurensuche eines Grenzgängers:

das kompositorische Schaffen im Spiegel der Beschäftigung

mit Sprache, Atem, Schweigen

640 S. 2004. ISBN 3-03910-354-7

Band 3 Walter Ludwig Bühl

Musiksoziologie

394 S. 2004. ISBN 3-03910-448-9

Band 4 Nikolaus Urbanek

Spiegel des Neuen: Musikästhetische Untersuchungen zum Werk Friedrich Cerhas

230 S. 2005. ISBN 3-03910-445-4

Band 5 Daniel Muzzulini

Genealogie der Klangfarbe

598 S. 2005. ISBN 3-03910-458-6

Band 6 James K. Wright

Schoenberg, Wittgenstein and the Vienna Circle

191 S. 2005, 2007.

ISBN 978-3-03911-287-6 / US-ISBN 978-0-8204-8935-3

Band 7 Ellen Taller

Gaetano Donizetti - Moment und Prozess

Studien zur musikalischen Dramaturgie.

249 S. 2005. ISBN 3-03910-637-6

Band 8 Rudolf Flotzinger

Von Leonin zu Perotin:

Der musikalische Paradigmenwechsel in Paris um 1210.

504 S. 2007. ISBN 978-3-03910-987-6 
Band 9 Isabelle Marc Martínez

Le rap français - Esthétique et poétique des textes (1990-1995)

327 S. 2008. ISBN 978-3-03911-482-5

Band 10 Fiona McAlpine

Tonal Consciousness and the Medieval West.

474 S. 2008. ISBN 978-3-03911-506-8

Band11 Massimo Zicari

The Land of Song. La "Terra del Belcanto" nella stampa londinese di fine Ottocento. Una raccolta di testi critici tra 1890 e 1900

266 S. 2008. ISBN 978-3-03911-507-5

Band 12 Marion Lamberth

Interaktion von Leben und Werk bei Schönberg.

Analysiert anhand seiner Ehekrise des Jahres 1908

279 S. 2008. ISBN 978-3-03911-515-0

Band 13 Claude Dauphin (éd.)

En collaboration avec Raymond Court, Yves Jaffrès,

Michael O'Dea, Daniel Paquette et Pierre Saby

Le Dictionnaire de musique de Jean-Jacques Rousseau:

une édition critique.

890 S. 2008. ISBN 978-3-03911-620-1

Band 14 Pascale Duhamel

Polyphonie parisienne et architecture

au temps de l'art gothique (1140-1240).

266 S. 2010. ISBN 978-3-03911-613-3

Band 15 Giuliano Castellani

Ferdinando Paer.

Biografia, opere e documenti degli anni parigini.

668 S. 2008. ISBN 978-3-03911-719-2

Band 16 Gustav Becking

How Musical Rhythm Reveals Human Attitudes.

An Annotated Translation by Nigel Nettheim.

336 S. 2011. ISBN 978-3-0343-0308-8 
Band 17 Anne Ibos-Augé

Chanter et lire dans le récit médiéval.

La fonction des insertions lyriques dans les œuvres narratives et didactiques d'oil aux XIII ${ }^{\mathrm{e}}$ et XIV $\mathrm{X}^{\mathrm{e}}$ siècles.

Vol. I; Vol. II: Annexes musicales et littéraires.

2010. ISBN 978-3-0343-0032-2

Band 18 Erik Kjellberg (ed.)

The Dissemination of Music in Seventeenth-Century Europe. Celebrating the Düben Collection. Proceedings from the International Conference at Uppsala University 2006. 358 S. 2010. ISBN 978-3-0343-0057-5

Band 19 Martin van Schaik

Der musikalische Wortschatz von Notker Labeo.

Wortkonkordanz und musikbezogener Kommentar.

188 S. 2012. ISBN 978-3-0343-1188-5

Band 20 Eric Lecler

L'opéra expressionniste.

120 S. 2010. ISBN 978-3-0343-0313-2

Band 21 Teresa Proto, Paolo Canettieri \& Gianluca Valenti (eds)

Text and Tune. On the Association of Music and Lyrics in Sung Verse.

371 S. 2015. ISBN 978-3-0343-1560-9

Band 22 Christiane Heine \& Juan Miguel González Martínez (eds)

The String Quartet in Spain.

650 S. 2016. ISBN 978-3-0343-1692-7

Band 23 Gregory Myers

Music and Ritual in Medieval Slavia Orthodoxa.

The Exaltation of the Holy Cross

231 S. 2017. ISBN 978-3-0343-2819-7

Band 24 Pervinca Rista

At the origins of Classical opera

Carlo Goldoni and the dramma giocoso per musica

XXX S. 2018. ISBN 978-3-0343-3551-5 
Pervinca Rista - 978-3-0343-3564-5

Downloaded from PubFactory at 01/11/2019 02:35:03AM

via free access 